\title{
Intenzív ultraibolya lézerimpulzusok intenzitáskontraszt javítása
}

PhD értekezés

Gilicze Barnabás

Témavezető:

\author{
Dr. Szatmári Sándor \\ egyetemi tanár \\ Kísérleti Fizikai Tanszék
}

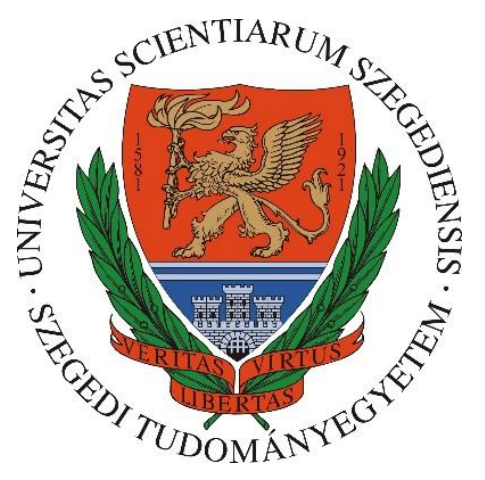

Fizika Doktori Iskola

Szegedi Tudományegyetem, Természettudományi és Informatikai Kar

Szeged

2020 


\section{Tartalomjegyzék}

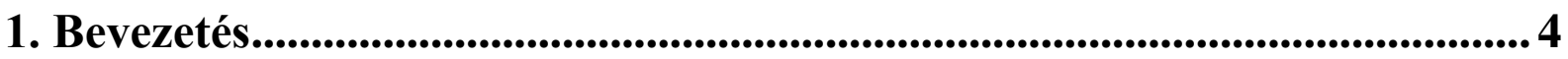

2. Tudományos elôzmények.............................................................................. 7

2.1 Nagyintenzitású szilárdtest lézerek felépítése ........................................................... 10

2.2 Nagyintenzitású excimer lézerek felépítése ………….......................................... 13

2.3. Nagyintenzitású impulzusok kontrasztjának javítására bevezetett technikák ................ 18

2.3.a. A magimpulzus energiájának növelése ……………………………………….... 18

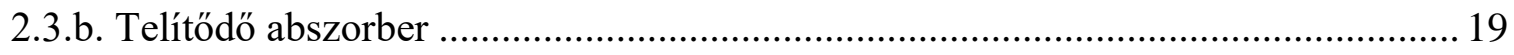

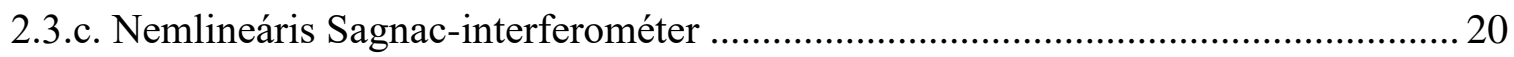

2.3.d. Nemlineáris ellipszis-rotáció .......................................................................... 22

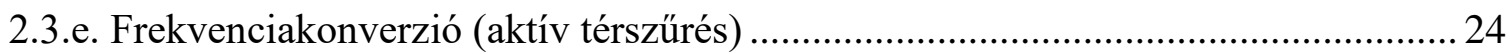

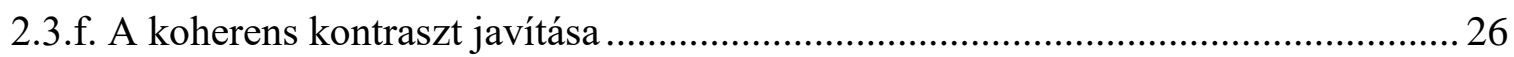

2.3.g. Kereszt-polarizált hullámkeltés …………………………………………….... 27

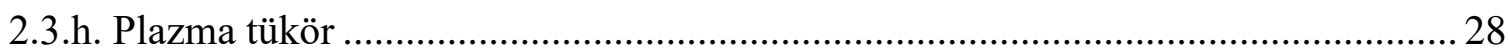

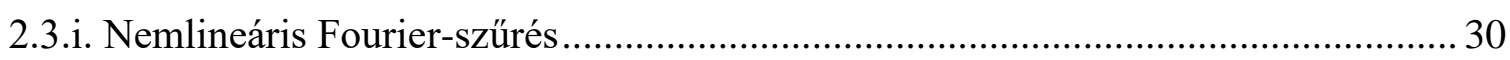

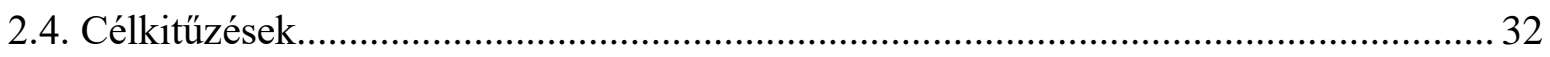

3. Tudományos eredmények.............................................................................34

3.1. Plazma tükör ultraibolya impulzusokra vonatkozó reflexiójának növelése .................. 34

3.1.a. Plazma tükör reflexiójának vizsgálata 500 fs hosszúságú impulzusokkal.............. 34

3.1.b. Plazma tükör reflexiójának vizsgálata 220 fs hosszúságú impulzusokkal.............. 40

3.1.c. Plazma tükör eljárással szürt impulzusok térbeli tulajdonságainak vizsgálata ....... 43

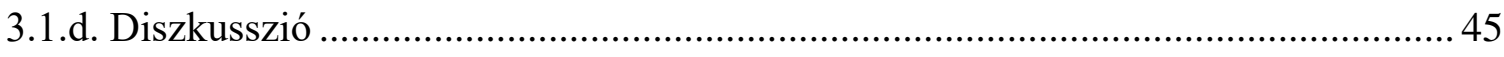

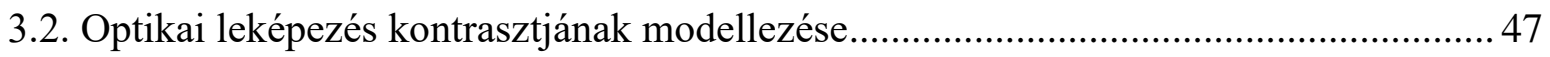

3.2.a. Optikai leképezés térfrekvenciás analízisen alapuló szimulációja......................... 47

3.2.b. Optikai leképező rendszerek térbeli kontrasztjának modellezésére kapott

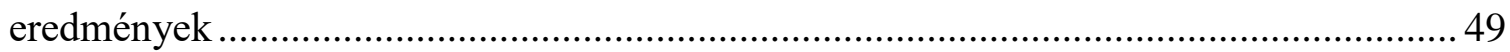

3.2.c. Leképezés térbeli kontrasztjavításának lehetőségei ............................................. 52

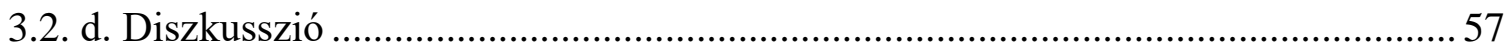

3.3. A nemlineáris Fourier-szürő kontrasztjavításának kiterjesztése .................................. 58

3.3.a. Optikai leképezés kontrasztjának kísérleti javítása............................................. 58

3.3.b. A nemlineáris Fourier-szüréssel elérhető kontrasztjavulás kísérleti vizsgálata...... 62

3.3.c. Az elérhető kontrasztjavulás növelésének kísérleti vizsgálata................................ 66 
3.3.d. Diszkusszió

3.4 Nemlineáris Fourier-szürés nagyintenzitású excimer lézerrendszerbe való integrálása 73

3.4.a. Nemlineáris Fourier-szürés erősítési átmenetek közé integrálása........................... 73

3.4.b. Nagy kontrasztú impulzusok erősítése................................................................ 80

3.4.c. A nagy időbeli kontraszttal rendelkező nagyintenzitású excimer lézerrendszer

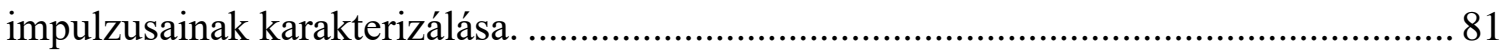

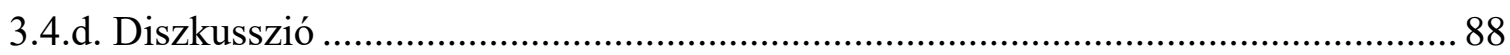

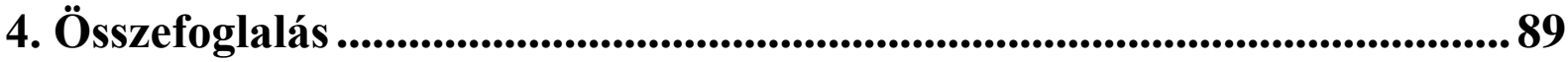

5. Summary .......................................................................................................... 93

6. Köszönetnyilvánítás .......................................................................97

7. Irodalomjegyzék ...................................................................................98 


\section{Bevezetés}

Az elmúlt évtizedekben a lézer technológia fejlődése nagyszámú új tudományos eredmény alapját képezte a fizika, az orvostudomány, a biológia és az anyagtudományok területén. A fizika területén az új tudományos felfedezések jelentős része a fény-anyag kölcsönhatási kísérletekhez köthető, ahol a nagyintenzitású lézerekkel kelthető elektromos terek nagysága meghaladja az atomok belsejében lévő elektromos tér nagyságát. Ezek alapján elmondható, hogy a lézerek csúcsintenzitásának növelése kulcsfontosságú szerepet tölt be a kutatásokban. Az elérhető csúcsintenzitás tekintetében a Q-kapcsolás és módusszinkronizáció technikák mellett a fázismodulált impulzuserősítési sémán (Chirped Pulse Amplification, CPA) [1] alapuló lézertechnológia jelentette a legnagyobb előrelépést. A CPA séma használatával jelenleg $10^{23} \mathrm{~W} / \mathrm{cm}^{2}$ intenzitás elérése is lehetséges, ami lehetővé teszi a relativisztikus elektrodinamika vizsgálatát [2-6]. A fázismodulált erősítési séma bevezetésért Gerard Mourou és Donna Strickland 2018-ban fizikai Nobel-díjat kapott. Megjegyzendő, hogy a 80-as évek végén és 90-es évek elején az elérhető legnagyobb fókuszált intenzitást az ultraibolya (UV) tartományban müködő KrF erősítő közegü rövid impulzusú lézerrendszerek biztosították. A világon jelenleg több nagyintenzitású lézerfizikával foglalkozó kutatói létesítmény müködik, ezek közül kiemelendő az európai ELI projekt (Extreme Light Infrastructure), amelynek keretében Szegeden [7-9], Prágában [10-12] és Bukarestben [13] épültek kutatóintézetek. A projekt egyik célkitüzése a $10^{25} \mathrm{~W} / \mathrm{cm}^{2}$ fókuszált intenzitás elérése.

A nagy intenzitású terek perspektivikus alkalmazásai közé tartoznak a monoenergetikus és jól fókuszálható részecskeforrások (nagy energiájú elektronok és ionok) létrehozása [1420], valamint fundamentális jelenségek vizsgálata lézer-plazma kölcsönhatások során [21]. A nagyintenzitású lézerek emellett széles spektrumtartományt lefedő másodlagos források alapját is képezik. Femtoszekundumos (fs-os) röntgensugárzás előállítása egyrészt az elektron relativisztikus mozgásával (betatron sugárzás, Compton-szórás, Thomson-szórás) [22-25], másrészt az optikai tartományban müködő lézer magasharmonikusainak keltésével is lehetséges [26]. Ez utóbbi módszeren alapszik az attoszekundumos impulzusok előállítása az extrém ultraibolya tartományban (XUV) [27]. Az ilyen módon keltett másodlagos forrásokat többek között nem-egyensúlyi ultragyors spektroszkópiához használják. Ultrarövid, nagy energiájú impulzusok segítségével az optikai spektrum másik oldalán található $\mathrm{THz}$ frekvenciájú ultragyors elektromos terek keltésére és alkalmazására is lehetőség nyílik [28]. 
Ugyanakkor a csúcsintenzitás növelésén túl egyre növekvő szerepet kap a tudományos kutatásban az impulzusok tér- és időbeli minőségének javítása. A több nagyságrenddel kisebb, a főimpulzust időben megelőző előimpulzus ugyanis előplazmát kelthet. Ebben az esetben a főimpulzus elsődlegesen ezen elöplazmával hat kölcsön, ami jelentősen befolyásolja a fény-anyag kölcsönhatási kísérletek jellegét és kimenetelét. A nagyintenzitású impulzusok időbeli tisztaságát/minőségét a főimpulzus és az előimpulzus intenzitásának hányadosával, az időbeli vagy intenzitáskontraszttal jellemzik. A rövid impulzusú lézerek által elért és a közeli jövőben célul kitűzött csúcsintenzitásokat, valamint a szilárdtestek plazmakeltési intenzitásküszöbét figyelembe véve az intenzitáskontraszt elvárt értéke $10^{13}-10^{15}$. Bizonyos kísérleteknél azonban megfigyelték, hogy még a plazmakeltési küszöbnél alacsonyabb intenzitású előimpulzusok is jelentősen befolyásolják a fény-anyag kölcsönhatási kísérletek sikerét [29, 30], így a kontrasztra vonatkozó kívánt érték várhatóan még az előbbi becslésnél is magasabb $\left(>10^{15}\right)$.

Az időbeli háttér a szilárdtest lézerek esetében egyrészt az erősített spontán emisszióból, (amplified spontaneous emission, ASE) másrészt az erösítési séma által bevezetett fázismoduláció nem tökéletes kompenzálásából és parazitareflexiókból származik. Egy ilyen lézerrendszer esetében az intenzitáskontraszt tipikusan nem haladja meg a $10^{8}$ értéket. $\mathrm{Az}$ elmúlt két évtizedben ezért több, a kontraszt javítását célzó eljárást is kifejlesztettek és alkalmaztak nagyintenzitású lézerimpulzusokra. A bevezetett módszerek közül kiemelkedik a plazma tükrön és a keresztpolarizált hullámkeltésen alapuló technika. A kontrasztjavító technikák alkalmazásával $>10^{12}$ értékű intenzitáskontrasztot sikerült elérni, ami extrém magas érték, de nem teljesíti az ideális kísérleti feltételeket.

Egyes nagyintenzitású kölcsönhatási kísérleteknél (pl.: XUV/röntgensugárzás generálása, szub-mikronos anyagmegmunkálás és olyan lézer-plazma kölcsönhatások, ahol az instabilitások hangsúlyos szerephez jutnak) elönyösebb rövidebb hullámhossz illetve magasabb fotonenergia használata [30-32]. Az ultraibolya tartományban müködő rövid impulzusú KrF excimer lézerrendszereket kedvező tulajdonságaik miatt számos kísérletben alkalmazzák és az infravörös tartományban müködő szilárdtest lézerek komplementer fényforrásaként is használják. Moderált csúcsteljesítményük ellenére a rövid impulzusú $\mathrm{KrF}$ excimer lézerrendszerekkel a jó fókuszálhatóságuk miatt $10^{19} \mathrm{~W} / \mathrm{cm}^{2}$ intenzitás is elérhető [33-35]. Az ilyen típusú lézerrendszerek jellemzően nem használják a fázismodulált impulzuserősítési sémát; a rövid impulzus erősítése direkt módon történik. Továbbá a rövid impulzus keltése és erősítése különböző hullámhosszon történik, melyet egy nemlineáris 
frekvenciakonverzió választ el egymástól. A nemlineáris frekvenciakonverzió és a direkt erősítés eredményeként ezek a lézerrendszerek eredendően jobb intenzitáskontraszttal rendelkeznek, ahol az időbeli háttér egyetlen forrása az erősített spontán emisszió. Az impulzus energiájának növelésével azonban az erősített spontán emisszió energiája rohamosan nő. $15 \mathrm{~mJ}$ impulzusenergia mellett tipikusan $10^{10}$ intenzitáskontraszt érhető el, ugyanakkor a nagyobb energiákra való erősítés itt is szükségessé teszi kontrasztjavító technikák bevezetését.

A rövid impulzusú $\mathrm{KrF}$ lézerrendszerek kontrasztjának javítására korábban sikerrel alkalmazták a plazma tükör technikát [36, 37] valamint a nemlineáris Fourier-szürést [38]. Ezen technikákkal a kontrasztjavítás értéke 2-3 nagyságrendre korlátozódik. Az első esetben az elérhető nagy- és kisjelü reflexió hányadosa miatt, az utóbbi esetben pedig egy a nemlineáris kölcsönhatástól független, diffrakcióra visszavezethető jelenség miatt. Mindkét módszer továbbfejlesztése igen perspektivikus a rövid impulzusú $\mathrm{KrF}$ intenzitáskontrasztjának növelésére továbbá utóbbi technika a szilárdtest lézerrendszerekben is alkalmazást nyerhet.

Jelen értekezés témája a rövid impulzusú $\mathrm{KrF}$ lézerrendszerek kontrasztjavítási lehetőségének vizsgálata továbbá egy nagyintenzitású és nagy intenzitáskontraszttal rendelkező ultraibolya lézerrendszer fejlesztése. A dolgozatom első felében bemutatom a nagyintenzitású lézerrendszerek általános felépítését, fontosabb típusait, elsősorban az intenzitáskontraszt vonatkozásában, valamint az eddig sikerrel alkalmazott kontrasztjavító technikákat. Az értekezés második felében 4 pontban mutatom be a munkám során elért új tudományos eredményeimet. Az első pontban bemutatom a plazma tükör ultraibolya impulzusokra vonatkozó reflexiójának növelésére valamint a nyaláb térbeli tulajdonságainak vizsgálatára irányuló kísérleteimet. A második pontban bemutatom a nemlineáris Fourierszürés kontrasztjavítását limitáló optikai leképezés elméleti modellezését és elméleti úton megvizsgálom a leképezés javításának lehetséges módjait és javaslatot teszek egy továbbfejlesztett nemlineáris Fourier-szürési elrendezésre. A harmadik pontban bemutatom az optikai leképezés térbeli kontrasztjának több nagyságrendet meghaladó javításának kísérleti megvalósítását, mind a látható, mind az ultraibolya tartományban. Bemutatom a nemlineáris Fourier-szürés által elérhető kontrasztjavulás kiterjesztését. A negyedik pont a nemlineáris Fourier-szürést magába foglaló nagyintenzitású és nagy kontrasztú ultraibolya lézerrendszer fejlesztésére és impulzusainak karakterizálására vonatkozó eredményeimet tartalmazza. 
A dolgozatomban ismertetett kísérleteket a Szegedi Tudományegyetem Kísérleti Fizikai Tanszékén müködő Nagyintenzitású Lézerlaboratóriumban (HILL) végeztem.

\section{Tudományos elózmények}

Nagy intenzitású elektromágneses terek keltése adott energiájú sugárzás extrém kis térbeli és időbeli koncentrációja révén lehetséges. Az elektromágneses hullámok térbeli koncentrációját a diffrakció jelensége limitálja. Egy térben teljesen koherens hullám esetén a fókuszálás során elérhető legkisebb foltméret $(x)$ a hullámhosszal $(\lambda)$ és a fókuszálás nyílásszögével az alábbi összefüggés szerint skálázódik

$$
x \approx \mathrm{c}_{\mathrm{x}} \cdot \lambda \cdot f / d
$$

ahol $d$ a nyalábátmérő, $f$ a fókuszhossz, $c_{x}$ egy egységnyi nagyságrendű szorzófaktor amelynek értéke függ a nyaláb pontos alakjától.

Az elektromágneses hullámok időbeli koncentrációja is a térbelihez hasonlóan a hullámhosszal skálázódik. Egy időben teljesen koherens hullámcsomag esetén a legkisebb időbeli hosszt $(\Delta \tau)$ az impulzus spektrumának szélessége $(\Delta v)$ szabja meg a Heisenberg-féle határozatlansági relációnak megfelelően;

$$
\Delta v \cdot \Delta \tau \approx \mathrm{c}_{\tau}
$$

ahol $c_{\tau}$ egy egységnyi nagyságrendü konstans, amelynek értéke függ az impulzus pontos alakjától. A 2-2 egyenletben a frekvenciát a hullámhosszal helyettesítve a

$$
\Delta \tau \approx \frac{1}{c} \frac{\lambda}{\Delta \lambda} \cdot \lambda
$$

összefüggést kapjuk, ahol $c$ a fénysebességet jelöli. Látható, hogy az impulzusidő rövidítése a hullámhossz csökkentésével és a $\Delta \lambda / \lambda$ relatív sávszélesség növelésével lehetséges. Így a rövidebb központi hullámhosszú lézerek adott sávszélesség esetén elvileg elönyösebbek nagy intenzitású elektromos terek előállítására.

Érdemes azonban megjegyezni, hogy a hullámhossz csökkentésével egyre nagyobb kihívás a lézermüködés fenntartása a spontán és indukált emissziót leíró Einstein-féle A és B koefficiensek skálázódása miatt. Mint ismeretes köztük az

$$
A \sim B \cdot v^{3}
$$

arányosság áll fenn. Azaz a spontán emisszió valószínűsége a frekvencia növelésével (a hullámhossz csökkentésével) rohamosan nő, így a gerjesztett szint élettartama drasztikusan 
csökken. Ez az elsődleges oka annak, hogy az extrém ultraibolya és röntgen tartományban a mai napig nehézséget jelent koherens fényforrást az adott hullámhosszon müködő lézerműködéssel előállítani. Helyette inkább az optikai tartományban müködő fényforrások impulzusait konvertálják valamely nemlineáris folyamat segítségével pl. magasharmonikuskeltésével [26, 39].

A nagyintenzitású impulzusok fény-anyag kölcsönhatási kísérletekben való alkalmazása számos nagy figyelmet kiváltó, új tudományos eredmény és másodlagos sugárzásforrás alapját képezi. Az alkalmazások közül kiemelt jelentőséggel bír a lézer-plazma energiatranszfer vizsgálata, a rövid idejü, kis divergenciájú, hangolható és közel monoenergetikus részecskegyorsítás, attoszekundumos XUV impulzusok keltése és ultragyors spektroszkópiára történő alkalmazása, koherens és ultragyors XUV és röntgensugárzás keltése és alkalmazása, valamint egy rezgési ciklusnál rövidebb THz-es frekvenciájú sugárzás keltése és alkalmazása nem roncsoló diagnosztikához illetve képalkotáshoz.

A lézerekkel elérhető csúcsintenzitás hozzáférést enged a relativisztikus elektrodinamika vizsgálatához. A világ számos kutatóintézetében müködnek jelenleg a PW-ot meghaladó csúcsteljesítményü lézerrendszerek, amelyekkel $10^{22}-10^{23} \mathrm{~W} / \mathrm{cm}^{2}$ fókuszált intenzitás is elérhető [2-6]. Az elmúlt bő egy évtizedben azonban számos kísérlet mutatta meg, hogy a kölcsönhatás során nagyobb intenzitás eléréséhez elsősorban az impulzus tér és időbeli minőségén kell javítani [40-42]. A nagyintenzitású impulzusok ns-os időbeli környezetében ugyanis az erősített spontán emisszióból származó a csúcsintenzitásnál több mint 8 nagyságrenddel kisebb háttér jelenik meg. A később részletesen ismertetett fázismodulált impulzuserősítési sémát használó rendszerek esetén pedig a néhány 10 pikoszekundumos (ps-os) környezetben egy ennél lényegesen magasabb értékü exponenciálisan lecsengő hátteret illetve mellékimpulzusokat figyelhetünk meg.

Ezen időbeli háttér jelenléte számottevően befolyásolhatja a fény-anyag kölcsönhatási kísérletek kimenetelét. A legtöbb szilárdtest plazmakeltési intenzitásküszöbe $10^{10}-10^{11} \mathrm{~W} / \mathrm{cm}^{2}$ érték körül van. A főimpulzust időben megelőző ún. előimpulzus (zaj) már képes az anyagot ionizálni és a főimpulzus a megérkezésekor nem az eredeti céltárggyal, hanem az előimpulzus által keltett előplazmával fog kölcsönhatásba lépni. Ez az előplazma ugyanis a főimpulzus megérkezéséig kitágul, így az annak hatására kialakuló elektronsűrüség nagysága és profiljának minősége jelentősen módosul a zaj nélküli esethez viszonyítva. Ez jelentősen befolyásolja a céltárgy felszínén kialakuló elektronsűrűség skálahosszát [30]. Egyes kísérletekben még az ionizációs küszöb alatti előimpulzusok hatását is megfigyelték. (Az 
ionizációs küszöb alatti lézer-anyag kölcsönhatások jól dokumentáltak az anyagmegmunkálás és az analitikus kémia területén.) Kimutatták, hogy a $10^{9} \mathrm{~W} / \mathrm{cm}^{2}$ nagyságrendü intenzitások esetében az ASE befolyással bír a transzmisszióra, reflexióra és a röntgensugárzás keltésére is [29, 43, 44]. Az ultraibolya tartományban szilárdtest-plazmával keltett felharmonikus generálás során már $10^{7} \mathrm{~W} / \mathrm{cm}^{2}$ intenzitású ASE hatását is észlelték [30]. Ez azt jelenti, hogy már $10^{7}-10^{8} \mathrm{~W} / \mathrm{cm}^{2}$ intenzitású előimpulzusokra is figyelmet kell fordítani a kísérletek során. Ennek oka, hogy az ionizációs küszöb alatti ns hosszúságú előimpulzus felfüti a céltárgy felületét, ami párologni kezd. A főimpulzus pedig először ezt a gázt fogja ionizálni. Az előimpulzusok által keltett elöplazmák egyúttal azt is okozzák, hogy az ultrarövid impulzussal való kölcsönhatáskor nem ismerjük a kezdeti és határfeltételeket.

A kísérleti tapasztalatok azt mutatják, hogy a nagy intenzitású elektromos terek alkalmazásának többségénél jelentős szerepe van a nagy kontraszt biztosításának. Az olyan alkalmazások, mint magasharmonikusok keltése szilárdtestek felületén [26, 30, 45], röntgensugárzás keltése [22-25, 46] és alkalmazása ultragyors feloldású röntgen spektroszkópiában [47], lézeres ion-sugár gyorsítás [48], üreges hullámvezető (hollow core fiber, HCF) használatán alapuló frekvencia konverzió [49], valamint gyors elektronok és ionok keltése [14-21, 50] egyaránt nagy kontraszttal rendelkező impulzusokat feltételeznek.

Az impulzusok időbeli minőségét általában az időbeli vagy intenzitáskontraszttal jellemezzük, amit a főimpulzus csúcsintenzitásának és az időbeli háttér intenzitásának hányadosaként definiálunk. Megjegyzem, hogy ez nem jellemzi pontosan az előimpulzusok hatását, hiszen nem ionizáló intenzitásszint alatt elsősorban a céltárgy felszíne által a főimpulzus megérkezéséig elnyelt energiasűrüség mérvadó. A fenti $\left(10^{7}-10^{8} \mathrm{~W} / \mathrm{cm}^{2}\right)$ küszöbértékek és csúcsintenzitások figyelembevételével az ideálisan elvárt intenzitáskontraszt $10^{13}-10^{16}$ közötti értékre tehető. Az elmúlt bő egy évtizedben számos eljárást fejlesztettek ki a lézerimpulzusok kontrasztjának javítására, ezek alapja általában egy intenzitás szerint nemlineáris folyamat, aminek segítségével részben szeparálni tudjuk a főimpulzust az időbeli háttértől.

Az impulzusok térbeli minőségét általában a fókuszsíkbeli eloszlásukkal jellemzik. Ez megmutatja a nyaláb által elszenvedett fázisfronttorzulásokat és egyúttal a közeli zónában mérhető eloszlás inhomogenitásáról is információt ad. Az eloszlás kvalitatív leírásának egyik módja, hogy a fókuszfolt átmérőjét összehasonlítjuk az ideális diffrakció-limitált elméleti értékkel. Egy másik szokásosan használt módszer, hogy az elért csúcsintenzitást összevetjük a 
diffrakció-limitált esetben várt csúcsintenzitással és a kettő hányadosát képezzük (Strehlhányados).

\subsection{Nagyintenzitású szilárdtest lézerek felépítése}

A világon jelenleg legelterjedtebb nagy intenzitású fényforrások az infravörös tartományban illetve annak határán müködő szilárdtest lézerek, amelyeknek aktív közege jellemzően titánnal szennyezett zafír kristály. Habár ezen lézerek központi hullámhossza (800 $\mathrm{nm}$ ) relatíve hosszú, de a titán-zafír kristály által megengedett spektrális sávszélesség nagyon kedvező $(\Delta \lambda / \lambda \approx 1 / 3)$. Ezt a sávszélességet kihasználva a rövid impulzusok generálása a módusszinkronizáció elvét használó oszcillátorral történik. Ennek lényege, hogy a lézer rezonátor módusai között állandó fáziskülönbséget rögzítünk, így ezek interferenciája révén femtoszekundumos időtartamú impulzussorozatot kapunk. Ilyen módusszinkronizált oszcillátorokkal jellemzően 5-20 fs-os, nJ nagyságrendbe eső energiájú impulzussorozatot lehet előállítani. Az impulzusok erősítéséhez jellemzően ugyancsak titán-zafír (bizonyos rendszereknél pedig LBO, BBO, DKDP vagy Nd-üveg [4]) kristályt használnak. A femtoszekundumos impulzusok direkt erősítése során problémát jelent, hogy az impulzus intenzitása még a $0,9 \mathrm{~J} / \mathrm{cm}^{2}$ telítési energiasürüség elérése előtt extrém nagy mértéküre nő és az olyan nemlineáris effektusok, mint az önfázismoduláció és önfókuszálódás/filamentáció tönkreteszik az impulzus idő- és térbeli eloszlását vagy az erősítő közeg roncsolódásához vezetnek. Ez az intenzitásszintbeli korlát sokáig áthidalhatatlan akadályt jelentett az energia növelésében, amíg 1985-ben G. Mourou és D. Strickland be nem vezették az ún. fázismodulált impulzuserősítési sémát (chirped pulse amplification, CPA) [1], amelynek lényege, hogy a rövid impulzust az erősítés előtt időben kinyújtják (jellemzően több száz psra, nagyobb energiájú rendszerek esetén 1 ns-ra) és az erősítést ezen lecsökkentet intenzitás mellett végzik. Erösítés után a korábban bevezetett fázismodulációt speciális impulzuskompresszor elrendezéssel kompenzálják. Az erősítési elrendezés elvi rajzát a 2-1. ábra mutatja. A nyújtáshoz/kompresszáláshoz rácsot, prizmát és fázismodulációt bevezető tükröt, egyes esetekben pedig egy szilárd, optikailag átlátszó anyag anyagi diszperzióját vagy ezek kombinációját alkalmazzák. A kompresszió után az impulzus időbeli szélessége megközelíti a transzformáció-limitált értéket (20-50 fs). Az elmúlt időkben számos kutatás célozta az összenyomás utáni impulzusidő további rövidítését. Különböző (később részben tárgyalt) technikákkal sikerült az impulzusidőt jelentősen csökkenteni, bizonyos lézerrendszerek esetén 5 fs alatti impulzusidőt is sikerült elérni [51-53]. 


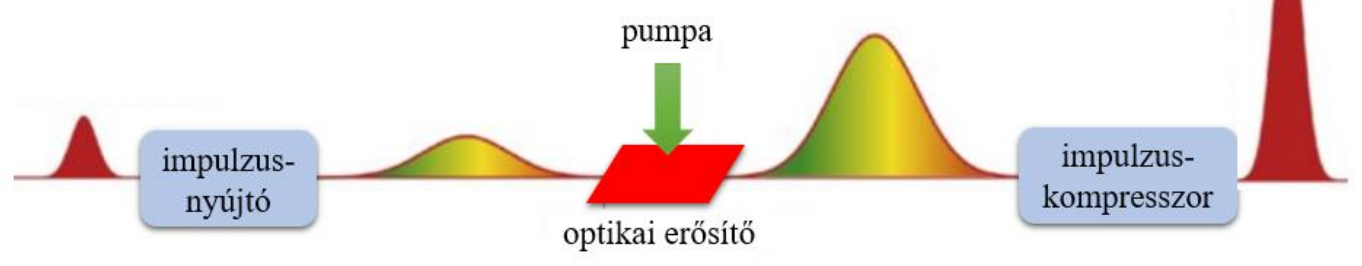

2-1. ábra

A fázismodulált impulzuserösitési séma (CPA) rajza.

A fázismodulált erősítési séma használatakor a kinyújtott impulzus erősítése a legtöbb rendszer esetén kétféle módon történhet. Az egyik esetben az erösítés egy segédlézerrel pumpált titán-zafír kristályban történik. Itt egy konfokális elrendezés közepén helyezkedik el a kristály, amelyben a nyaláb különböző szögekben 5-10 erösítési átmenetben erősödik. Egy másik szokásos elrendezés az ún. regeneratív erősítés, ahol elektro-optikai kapcsolókkal (Pockels-cella) és polarizátorokkal biztosítják a nyalábnak egy rezonátorhoz hasonló elrendezésbe való belépését és a többszöri erősítés/körbejárás utáni kicsatolását. Ez a technikai különbség jelentős eltérést okoz a nyalábprofil és a parazitareflexiók tekintetében.

A másik esetben egy nemlineáris harmadrendü folyamattal, az optikai parametrikus konverzióval erősítik az impulzust. Ez a különbségi frekvenciakonverzión alapuló eljárás jellemzően $\mathrm{LBO}, \mathrm{BBO}$ vagy DKDP kristályok segítségével történik. A parametrikus erősítés CPA sémával történő kombinálását röviden OPCPA (optical parametric chirped-pulse amplification) sémának szokás nevezni [54]. Vannak olyan lézerrendszerek, ahol a két erősítési módot hibrid módon alkalmazzák.

A nagyintenzitású szilárdtest lézerek intenzitáskontrasztját alapvetően két tényező befolyásolja. Az egyik az erősítésre használt gerjesztett közegből jövő erősített spontán emisszió, ami a föimpulzus nanoszekundumos (ns-os) időbeli környezetében van jelen és fizikai természetéből fakadóan inkoherens. Az időbeli háttérhez hozzájáruló ASE jellemzően az első erősítési fokozatokban keletkezik, ahol a bemenő jel energiasürüsége még nem éri el a közegre jellemző telítési energiaszintet, a követő erősítési átmenetekben pedig tovább erősödik. A regeneratív elrendezésű erősítők, mivel egy rezonátorhoz hasonlóan sok átmenettel dolgoznak jobban kedveznek az ASE kiépülésének. További hátrányuk, hogy a fényútban jelenlévő polarizátorok parazitareflexiókat eredményeznek a rendszer kimenetén. Ezzel szemben a többutas erôsítési elrendezés hátránya, hogy az erősítési átmenetek különböző szögének következtében az erősített nyaláb térbeli profilja gyakran torzul. 
Az OPCPA rendszerek esetén, mivel nem hagyományos indukált emisszión alapuló erősítők, nem keletkezik erősített spontán emisszió. Ilyen rendszereknél inkább a parametrikus fluoreszcencia okoz problémát, de ennek intenzitása kisebb és csak a pumpálás időtartamára szorítkozik ( 100ps). Az OPCPA sémát használó rendszerek ns-os skálán mért intenzitáskontrasztja ezért 1-2 nagyságrenddel jobb, mint a $\sim 10^{8}$ alatti kontrasztot produkáló hagyományos CPA sémát használó rendszereké.

A nagyintenzitású szilárdtest lézerek intenzitáskontrasztját befolyásoló másik tényező az impulzus 100 ps-os környezetében mérhető koherens háttér, ami a CPA séma inherens hátrányos tulajdonsága. A fázismodulált impulzuserösítés során ugyanis az impulzus spektrális amplitúdója és fázisa is torzul a nemlineáris folyamatok miatt. Az erősítés tulajdonságaiból kifolyólag az impulzus spektruma beszükül, ami a transzform-limitált impulzushossz növekedésén túl az időbeli alak torzulásához is vezet. A lézerrendszert alkotó optikai elemek véges spektrális tartománya ugyancsak spektrális vágáshoz vezethet, ami az időképben mellékimpulzusok megjelenését eredményezi. A diszperzív elemeken fellépő szórás is hozzájárul az impulzusok véges, limitált kontrasztjához. Ezek a hatások és a korábban bevezetett spektrális fázismoduláció nem tökéletes kompenzálása a föimpulzus 100 ps-os környezetében exponenciálisan lecsengő koherens hátteret és mellékimpulzusokat eredményez. A 2-2. ábrán látható egy CPA sémát használó nagyintenzitású titán-zafír lézerrendszer impulzusának harmadrendủ autokorrelációs görbéje. Megfigyelhető az ASE-ból származó ns-os háttér, valamint az exponenciálisan lecsengő koherens impulzustalpak és parazitareflexiók.
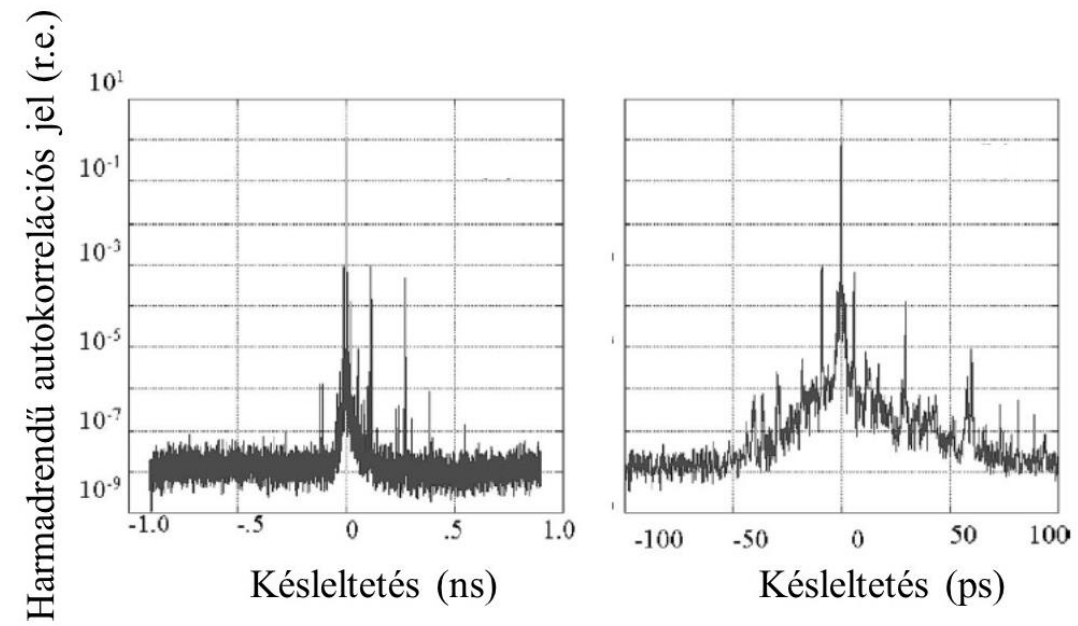

2-2. ábra

A Michigani egyetemen müködö HERCULES nagyintenzitású szilárdtest lézerrendszer impulzusainak harmadrendü autokorrelációs függvénye ns-os és ps-os skálán. [55] 
Mint később látni fogjuk, az intenzitáskontraszt javítását célzó technikák közös jellemzője, hogy egy intenzitástól nemlineárisan függő jelenségen alapulnak. A CPA sémát használó rendszerekben ezen technikákat nem lenne hatékony a kinyújtott föimpulzusra alkalmazni, mert a rosszabb jel/zaj viszony és kisebb csúcsintenzitás miatt a zaj az impulzus időablakában áthaladna. Ezért a kontrasztjavító technikákat vagy a rendszer végén, vagy ha a technika nagy energiaveszteséggel jár, akkor két CPA erösítési fokozat között jelen lévő kompresszált impulzusra alkalmazzák. Ez utóbbi elrendezésre terjedt el a double CPA vagy DCPA elnevezés [56]. Ennek lényege, hogy az első CPA fokozat által előállított néhány mJ energiájú impulzus kontrasztjavítása után a szub-mJ szintről folytatjuk az erősítést egy újabb CPA erősítési sémát használó fokozatban, ezáltal kisebb teret engedve az ASE kifejlődésének. A ns-os időskálán így kedvezőbb kontrasztot lehet elérni, azonban világos, hogy a második CPA fokozat miatt a ps-os környezetben lévő koherens kontraszt újból megjelenik.

A nagyintenzitású szilárdtest lézerek az elmúlt évtizedekben számtalan alapvető fontosságú tudományos felfedezést eredményeztek a fizikában és a társtudományok területén. A jelenlegi legfejlettebb rendszerek csúcsteljesítménye meghaladja a PW értéket [2-6] és a fókuszált intenzitás egyes esetekben eléri a $10^{23} \mathrm{~W} / \mathrm{cm}^{2}$ értéket.

\subsection{Nagyintenzitású excimer lézerek felépítése}

Mint ahogy azt a fejezet elején ismertettem, a rövidebb hullámhosszú lézerek nagyobb csúcsintenzitás elérésének lehetőségét hordozzák. Adott sávszélesség és energia mellett az intenzitás a frekvencia harmadik hatványával skálázódik. Koherens ultraibolya sugárzás keltésére az excimer lézerek a leghatékonyabbak. Az excimer lézerek olyan - általában halogén és nemesgáz atomokból álló kétatomos - molekulákat használnak a lézermüködéshez, amelyek csak gerjesztett állapotban léteznek, alapállapotban spontán disszociálnak (excited dimer) [57]. Az excimerek különböző gázkeverékü változatainak központi hullámhossza 126 és 351 nm közé ill. 490 nm-re és környékére esik. Ez utóbbi látható tartományba eső lézermüködést a $\mathrm{XeF}$ molekula $\mathrm{C} \rightarrow \mathrm{A}$ átmenetének használatával sikerült elérni [58]. Az 1980-as és 90-es években a nagyintenzitású lézerek fejlődésének egyik ágát az olyan ultraibolya lézerrendszerek jelentették, ahol a rövid impulzusok erösítését excimer lézerekkel végezték [59-71]. Mivel a spontán emisszió valószínűségének skálázódása és az ultraibolya tartományban igen jelentős anyagi diszperzió ellehetetleníti a rövid impulzusú oszcillátorok müködését, ezért ezeknél a lézerrendszereknél a magimpulzus generálása más hullámhosszon történik. Nagyintenzitású ultraibolya fényforrásokat az elmúlt évtizedekben ArF (193 nm) 
[59, 60], $\mathrm{XeCl}(308 \mathrm{~nm})$ [61-65] és $\mathrm{XeF}(351 \mathrm{~nm}$ ill. $475 \mathrm{~nm})$ [66, 67] excimerekkel is állítottak elö, de a rövid impulzusok erősítésére a legsikeresebben a $\mathrm{KrF}(248,5 \mathrm{~nm})$ közeget alkalmazták [68-73]. Ennek egyik oka, hogy az excimerekre irányuló erősítés dinamikai vizsgálatok azt mutatták [73], hogy a rövid impulzusok erősítése tekintetében csak a $\mathrm{KrF}$ és ArF közeg őrzi meg a négy-szintes tulajdonságát, ami a hatékony energiakinyerés szükséges feltétele. A megmaradó két excimer vonatkozásában pedig részben technikai szempontok preferálják a KrF használatát (könnyebb frekvenciakonverzió, nagyobb térfogatok gerjesztése, elérhető optikák száma). A továbbiakban ezért elsősorban a nagyintenzitású $\mathrm{KrF}$ lézerrendszerek leírására szorítkozom. A KrF közeg a viszonylag rövid erősítési hullámhossz mellett aránylag kis relatív sávszéleséggel rendelkezik $(\Delta \lambda / \lambda \approx 1 / 300)$, így az erősített impulzusok transzform-limitált hossza $\sim 100$ fs-ra korlátozódik. Az erősítő csövek ablakaiban fellépő önfázismoduláció okozta spektrális kiszélesedésre alapozva egyes esetekben a kompresszált impulzus hossza elérte a 50 fs-ot [73]. A szilárdtest lézereknél szokásos üreges hullámvezetőben fellépő önfázismoduláció és kompresszor kombinációjának használatán alapuló eljárással sikerült az impulzusidőt 20 fs-ra csökkenteni [74] $200 \mu \mathrm{J}$-os energiaszint mellett [75]

A KrF rendszerekben a rövid magimpulzus keltése vagy az infravörös tartomány határán módusszinkronizált titán-zafír oszcillátorral történik vagy a látható tartományban müködő rövid impulzusú festéklézerrendszerrel. Az első esetben a harmadik harmonikus keltésével az utóbbi esetben másodharmonikus-keltésével egy nemlineáris kristály (jellemzően $\mathrm{BBO}$ ) segítségével konvertálják az impulzus hullámhosszát a $\mathrm{KrF}$ erősítési sávjába. A szilárdtest oszcillátort használó rendszerek esetében a rövid magimpulzusokat egyes esetekben a frekvenciakonverzió előtt direkt módon erősítik szilárdtest erősítőkben. A rövid impulzusú festéklézerrendszert tartalmazó $\mathrm{KrF}$ rendszer sematikus rajzát a 2-3. ábra mutatja. A magimpulzus generálása egy impulzus üzemű elosztott visszacsatolású festéklézerrel történik (EVFL, distributed feedback dye laser, DFDL). A hangolható fényforrás néhány száz fs hosszúságú impulzusok generálását teszi lehetővé. Az ezt megelőző festéklézerek a DFDL-t pumpáló impulzus rövidítéséért, a DFDL utáni festékerősítők pedig a rövid jel látható tartományban való erősítéséért felelősek.

A $\mathrm{KrF}$ erősítő közeg telítési energiasürüsége (a részecskesürüség okán) lényegesen (3 nagyságrenddel) kisebb, mint pl. a titán-zafír közegé. A $\mathrm{mJ} / \mathrm{cm}^{2}$ nagyságrendű telítési energiasürüség és a szub-pikoszekundumos impulzushossz lehetővé teszi a rövid impulzusok direkt, fázismoduláció nélküli erősítését. Az impulzus intenzitása az erősítés során nem éri el 
azt a szintet, hogy a közegben jelentős mértékü önfázismoduláció vagy önfókuszálódás lépjen fel, így nem szükséges a szilárdtest lézereknél használatos CPA séma bevezetése. Meg kell azonban jegyezni, hogy az erősítő ablakok esetében ezekre az effektusokra és az UV tartományban már ezen intenzitásokon is jelentős nemlineáris abszorpcióra külön gondot kell fordítani.

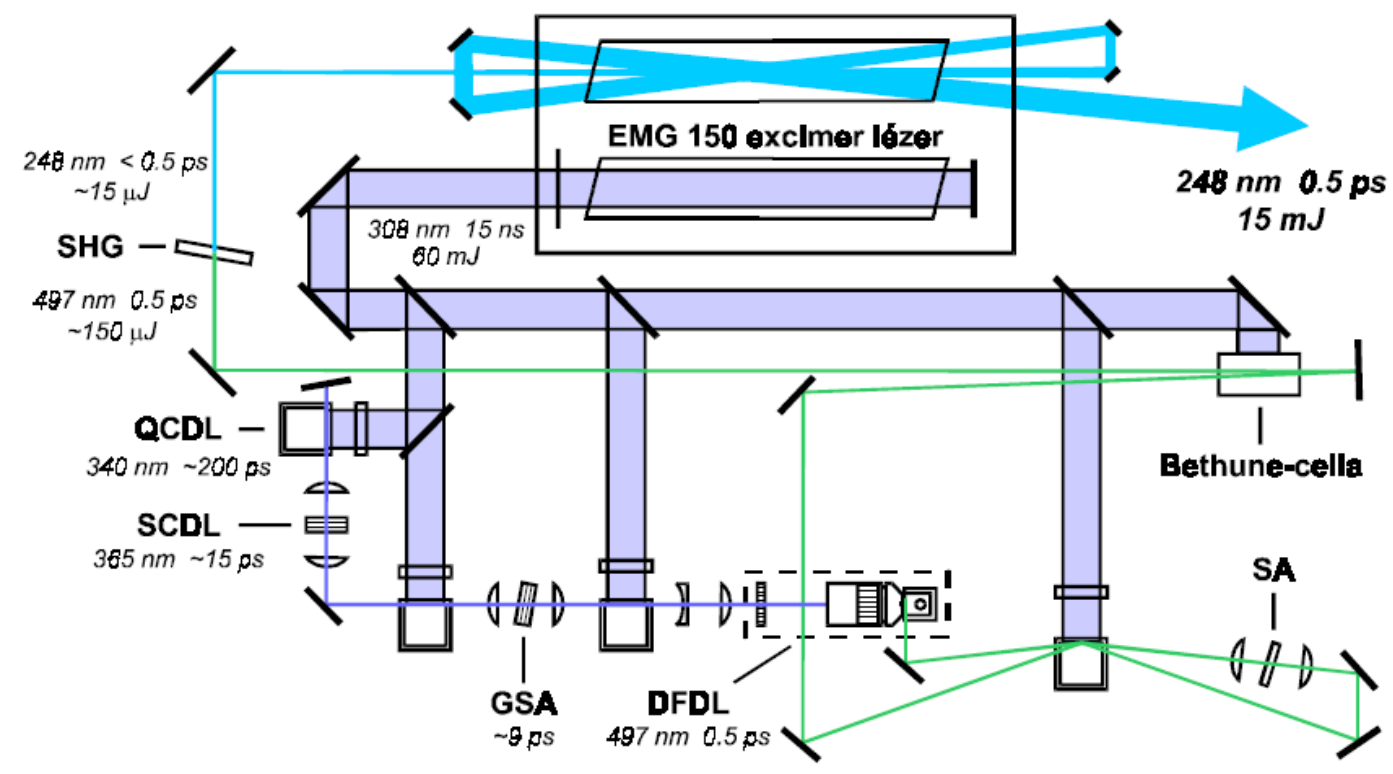

\section{2-3. ábra}

Nagyintezitású KrF festék-excimer lézerrendszer sematikus rajza.

QCDL: kioltott festéklézer, SCDL: rövid rezonátorú festéklézer, GSA: kapuzott telitődö abszorbens, DFDL: elosztott visszacsatolású festéklézer, SA: telitödö abszorber SHG:

\section{frekvenciakétszerezö [76]}

A KrF közeg fontos tulajdonsága, hogy a telítődő erősítés mellett a nem telítődő abszorpció jelensége is fellép az alapállapotú $\mathrm{F}_{2}$ valamint $\mathrm{a} \mathrm{Kr}_{2}{ }^{+}, \mathrm{F}^{-}$ionok és a kétszeresen gerjesztett $\mathrm{Kr}^{* *}$ atomok abszorpciója miatt. Mint arra M. M. Tilleman és J. H. Jacob [77] valamint S. Szatmári és munkatársai [78] rámutattak, ez komoly megszorítást jelent az erősítés optimumára vonatkozóan. A 2-4. ábrán látható a telítési energiasürüségre normált energiasűrüség $(\varepsilon)$ függvényében az energiakinyerési hatásfok, ami megmutatja, hogy az erősítőben pillanatnyilag tárolt energia mekkora részét nyerjük ki a rövid impulzussal. Látható, hogy a görbe egy maximummal rendelkezik a telítési energiasürüség kétszeres értéke körül. Ez azt jelenti, hogy az erősítés során az impulzus energiasürüségét ezen érték körül (vagy a kontrasztra való tekintettel ez alatt) kell tartani. Az erősítés miatt növekvő energia mellett ez csak növekvő nyalábméret és növekvő keresztmetszetü erősítőközeg mellett lehetséges. A 2-4. ábrán ugyancsak fel van tüntetve a kontraszt koefficiens, ami az $\varepsilon$ 
energiasűrüségü rövid jelre és a messze telítés alatti kis jelre (erősített spontán emisszióra) vonatkozó erősítési együtthatók hányadosát adja meg. Látható, hogy jelentős kontrasztromlás elkerülése csak kis energiasürüségek mellett lehetséges.

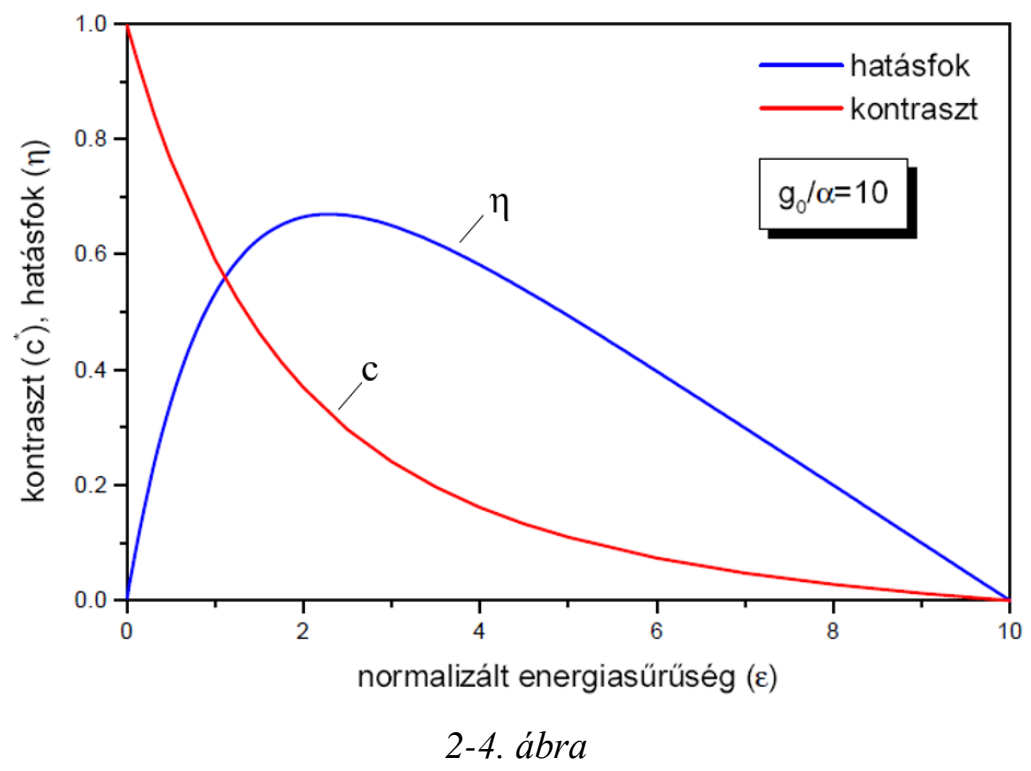

Az energiakinyerési hatásfok ( $\eta$ és a kontraszt koefficiens (c) a telitési energiasürüségre normalizált energiasürüség (ع) függvényében $\mathrm{KrF}$ erösitöre. ( $g_{0}$ és a a kis jelü erösitési és az abszorpciós tényezö) [76]

Ezen probléma részleges megoldására vezették be S. Szatmári és munkatársai az ún. döntött tengelyü erősítési sémát [78]. Ennek lényege, hogy az adott - általában hosszúkás erősítő közegen az enyhén divergáló nyaláb egyre nagyobb szögben halad át. Ezáltal a nyaláb (az egyik dimenzióban) egyre növekvő keresztmetszet lát így az energiasürüsége elvileg illeszthető az adott erősítési átmenetre.

A KrF erősítő közegek másik tulajdonsága, hogy a gerjesztett szint élettartama néhány ns, míg a pumpált szint élettartama és a pumpálás gyorsasága együttesen nem rövidebb, mint 10ns időállandót eredményeznek. Ennek következtében a rövid impulzus számára a pillanatnyilag hozzáférhető energia optimális esetben is csak tört $(\sim 1 / 10)$ része a teljes tárolt energiának. Az erősítőn való többszöri egymás utáni áthaladással a tárolt energia nagyobb hányadához lehetne hozzáférni, de az energiasürüségre vonatkozó megkötések miatt még a döntött tengelyü erősítés alkalmazása esetén sem lehet 3-nál több átmenetet megengedni az ASE drasztikus növekedése és a hatásfok drasztikus csökkenése miatt. A problémára részleges megoldást az S. Szatmári és munkatársai által ultraibolya impulzusok erősítésére kidolgozott interferometrikus optikai multiplexelés elrendezés jelenti [79]. Ennek lényege, hogy az erősíteni kívánt impulzust két részre osztjuk és az így keletkező részimpulzusokat 
egymáshoz képest időben késleltetve erősítjük, majd a kimeneten interferometrikus pontosággal újra egyesítjük. Az optimális erősítési paraméterek külön mindegyik nyalábra teljesíthetők és a tárolt energia nagyobb hányadához férhetünk hozzá. Az interferometrikus pontosságot egy Sagnac-interferométerhez hasonló elrendezés biztosítja. Az irodalomban közölt adatok alapján a két résznyalábos elrendezés technikai jellegű veszteségek miatt 1,7szeresére növeli az impulzussal kinyerhető energiát. Az energia nagyobb hányadához való hozzáférést a multiplexelési elrendezés több nyalábra való felskálázása tenné lehetővé.

A titán-zafír oszcillátort tartalmazó rövid impulzusú KrF lézerrendszerek magasabb ismétlési frekvencián és ezért nagyobb átlagteljesítményen képesek müködni. J. Békési és munkatársai $30 \mathrm{~mJ}$ kimenő energia mellett 270 fs impulzushosszt ill. $50 \mathrm{~mJ}$ kimenő energia mellett 600 fs impulzushosszt tudtak elérni $[35,80]$. Ugyancsak J. Békési és munkatársai egy femtoszekundumos festéklézer magimpulzusait és két KrF erősítő fokozatot használva $100 \mathrm{~mJ}$ kimenő energiát produkáltak $\sim 600$ fs impulzushossz mellett [80]. Ebben az esetben a végerősítő fokozatot kétnyalábos optikai multiplexelési elrendezéssel egészítették ki. A festéklézert tartalmazó elrendezések ismétlési frekvenciája $10 \mathrm{~Hz}$ körüli. A csúcsteljesítmény és a kimenő energia tekintetében a legjobb eredményt C. Rhodes és munkatársai érték el, ahol a titán-zafír oszcillátor által szolgáltatott magimpulzusokat $\mathrm{KrF}$ excimer erősítőkkel 300-500 mJ energiára erősítették 200-300 fs impulzushossz mellet [33, 81]. f/2-es fókuszálás mellett 2 $\mu \mathrm{m}$-es fókuszfoltot eredményezett. A fent leírt lézerrendszerekről elmondható, hogy moderált csúcsteljesítményük ellenére a jó fókuszálhatóságuk miatt a csúcsintenzitásuk meghaladja a $10^{19} \mathrm{~W} / \mathrm{cm}^{2}$ értéket (specifikus intenzitásuk pedig a $10^{21} \mathrm{~W} / \mathrm{cm}^{2} \mathrm{sterad}^{-1}-\mathrm{t}$ ), ami egyedülálló lehetőséget nyújt nagyintenzitású fény-anyag kölcsönhatási kísérletek vizsgálatára $248 \mathrm{~nm}$-es hullámhosszon.

A nagyintenzitású $\mathrm{KrF}$ lézerrendszerek előnye, hogy a direkt erősítés miatt az időbeli kontrasztot egyedül a térben és időben egyenletes eloszlású erősített spontán emisszió szabja meg, így nem kell számolni a föimpulzus ps-os környezetében lévő koherens hátérrel. Az időbeli háttér ezen tulajdonsága miatt az intenzitáskontraszt meghatározása jóval egyszerübb; elég a főimpulzus energiáját, időbeli hosszát és fókuszálhatóságát összehasonlítani az ASE ezen tulajdonságaival. Mivel az ultraibolya tartományban ezideáig nem fejlesztettek ki elég nagy dinamikus tartománnyal rendelkező, az impulzus időbeli alakját mérni tudó eljárást, ezért kénytelenek vagyunk a fenti közvetett mérési módszerre hagyatkozni.

A kontraszt szempontjából ugyancsak meghatározó, hogy a KrF lézerrendszerekben az ultraibolya tartományban való erősítés előtt frekvenciakonverzió történik. Ez az intenzitás 
tekintetében nemlineáris folyamat egyúttal igen hatékony kontrasztjavító eljárás, hiszen a jóval kisebb intenzitású időbeli háttér sokkal kisebb hatásfokkal konvertálódik továbbá a megmaradó - későbbi fokozatokban nem erősödő - alapharmonikus teljesen szeparálható az ultraibolya impulzustól. Ebből adódóan az UV tartományban történő erősítés gyakorlatilag ideális kontraszttal rendelkező bemenő impulzussal indul. Ugyanakkor a rövid hullámhossz miatt az erősítési átmenetek számával az ASE drasztikusan növekszik. 15 mJ kimenő energia mellett az intenzitáskontraszt megközelíti a $10^{10}$ értéket. A 100 mJ-os energia tartományt elérve az intenzitáskontraszt $10^{8}-10^{9}$ értékre romlik. Az intenzív ultraibolya impulzusok kontrasztjának javítására ezért mindenképp szükséges egy hatékony kontrasztjavító technika bevezetése.

\subsection{Nagyintenzitású impulzusok kontrasztjának javítására bevezetett technikák}

Ebben a pontban az intenzitáskontraszt javítására szolgáló, eddig kifejlesztett technikákat ismertetem. A fejezet végén megfogalmazom az önálló tudományos munkám célkitűzéseit.

\section{3.a. A magimpulzus energiájának növelése}

A nagyintenzitású rendszerek intenzitáskontrasztjának javítására irányuló egyik leggyakoribb stratégia, hogy a végerősítő fokozatba szub-mJ energiájú és extrém nagy kontrasztú impulzusokat csatolunk be, mellyel az erősítőlánc elején keletkező ASE szerepe kizárható (a kimeneten mérhető ASE domináns része az erősítési lánc elején fejlődik ki). A végerősítő fokozat előtti kontrasztjavítással kompenzálható az elrendezés által okozott energiaveszteség és az erősítő telítésben való müködtetése miatt az ASE sem képes drasztikusan növekedni. Megjegyzem, hogy a rövid impulzus generálásáért felelős módusszinkronizált oszcillátorok energiájának növelésére széles körben folynak kutatások. A Kerr-lencsés módusszinkronizált oszcillárotok szub- $\mu \mathrm{J}$ energiájú tiszta impulzusokat tudnak szolgáltatni [82].

J. Itatani és munkatársai az oszcillátor magimpulzusait direkt módon - az önfázismoduláció és önfókuszálás elkerülése mellett - $\mu \mathrm{J}$-os energia szintre erősítették. A CPA fokozat előtt telítődő abszorber segítségével javították az impulzusok kontrasztját. A rendszer kimenetén az impulzusok kontrasztja két nagyságrenddel javult; $10^{7}$ értéket demonstráltak a ns-os skálán [83]. 
Ugyancsak ezen az elven alapszik a double CPA vagy DCPA rendszerek felépítése is. Itt az első CPA fokozat néhány $\mathrm{mJ}$ energiájú rövid impulzusokat állít elö, amit valamilyen kontrasztjavító technikával szürnek, majd az így nyert sub-mJ energiájú extrém nagy kontrasztú impulzussal folytatják az erősítést [56].

\section{3.b. Telítődő abszorber}

A telítődő abszorber (optikai kapcsoló) széles körben alkalmazott eszköz különböző típusú lézerek időbeli hátterének csökkentésére. A telítődő abszorpció jelensége egy nemlineáris folyamat, amely során a beeső fény lényegesen megváltoztatja (csökkenti) az abszorbeálni képes részecskék számát, így az anyag egy bizonyos intenzitás (rövid jelek esetén egy bizonyos energiasürüség) felett átlátszóvá válik. Rövid impulzusok kontrasztjavítása esetén az abszorberre eső energiasürüséget úgy kell megválasztani, hogy a föimpulzus felfutó éle éppen telítésbe (vagy közel telítésbe) vigye a használt anyag abszorpcióját. Ekkor az előimpulzus nagy része kiszürhető, ugyanakkor a főimpulzus kis energiaveszteséggel halad tovább.

Mivel a telítődő abszorberek jellemzően szilárdtestek, ezért a szilárdtest erősítőknél látott hasonló probléma merül fel az alkalmazásuk kapcsán. A telítési energiasürüség eléréséhez szükségképpen olyan nagy intenzitás társul, ami magával vonja az impulzus tér- és időbeli tulajdonságainak (továbbá az optikai elemek állapotának) drasztikus romlását eredményező nemlineáris folyamatok megjelenését. A megoldást a CPA sémához hasonlóan az jelenti, hogy a telítődő abszorbert kinyújtott impulzus esetében alkalmazzuk.

J. Wojtkiewicz és C. G. Durfee a kontraszt javításának érdekében egy konfokális, többutas titán-zafír erősítési elrendezésben helyezett el telítődő abszorbert oly módon, hogy a szürő 75\%-os transzmissziót és egy áthaladás során 2 nagyságrendnyi kontrasztjavulást eredményezzen. Az általuk fejlesztett lézerrendszer $10 \mathrm{~mJ}$-os kimenő energia mellett $10^{9}$ intenzitáskontraszttal rendelkezett a ns-os skálán [84].

A korábban említett kísérletben J. Itatani és munkatársai CPA elrendezésbe belépő $\mu \mathrm{J}$ energiájú impulzusok kontrasztját telítődő abszorberrel növelték. Az eljárással 2 nagyságrendnyi kontrasztjavulást értek el a kimeneten, melynek eredményeként a ns-os kontraszt $10^{7}$ értéküre nőtt [83].

S. Fourmaux és munkatársai a szilárdtest lézerrendszerükben az impulzusnyújtó előtt és az erősítés láncban is telítődő abszorbereket helyeztek a nyaláb útjába, amivel a 
lézerrendszerük kontrasztját $>10^{10}$ értékre tudták javítani mindössze 30\%-os energiaveszteség mellett [85].

A telítődő abszorberek egyik hátránya, hogy az áthaladás során az impulzus spektruma eltolódhat és beszükülhet. Másrészt az impulzus kinyújtásával lecsökken a jel és ASE közötti intenzitásarány, továbbá az időbeli átfedés nagyságrendekkel megnő a jel és zaj között, ami megnehezíti a hatékony zajszürést.

\section{3.c. Nemlineáris Sagnac-interferométer}

A. Renault és munkatársai egy olyan kontrasztjavító eljárást fejlesztettek ki, amely egy Sagnac-interferométerben bevezetett nemlineáris fázistoláson alapul [86]. Az elrendezés elvi rajza a 2-5. ábrán látható. Egy klasszikus Sagnac-interferométerben az impulzust egy nyalábosztó két részre osztja. A két impulzus ugyanazt az utat járja be ellentétes irányban. Amennyiben a nyalábosztó transzmisszós (T) és reflexiós $(\mathrm{R})$ együtthatója megegyezik (azaz a két irányban körbejáró részimpulzusok intenzitása ugyanaz), az interferométernek csak az egyik a bemenettel közös (A) kimenetén jelenig meg kimenő impulzus, a másik (B) kimenetén a kimenő intenzitás értéke nulla. Ha az interferométer fényútjába egy nemlineáris elemet $\left(\mathrm{L}_{1}\right)$ és egy szürőt $(\tau)$ helyezünk, akkor a kimenetek intenzitáseloszlása ill. kontrasztja megváltozik. Ismeretes, hogy egy nemlineáris elem törésmutatója - a Kerr effektusnak megfelelően - függ az impulzus intenzitásától $(I)$, nevezetesen az

$$
n(I)=n_{0}+n_{2} I
$$

összefüggés szerint, ahol $n_{0}$ a lineáris, $n_{2}$ pedig a nemlineáris másodrendü törésmutató. 


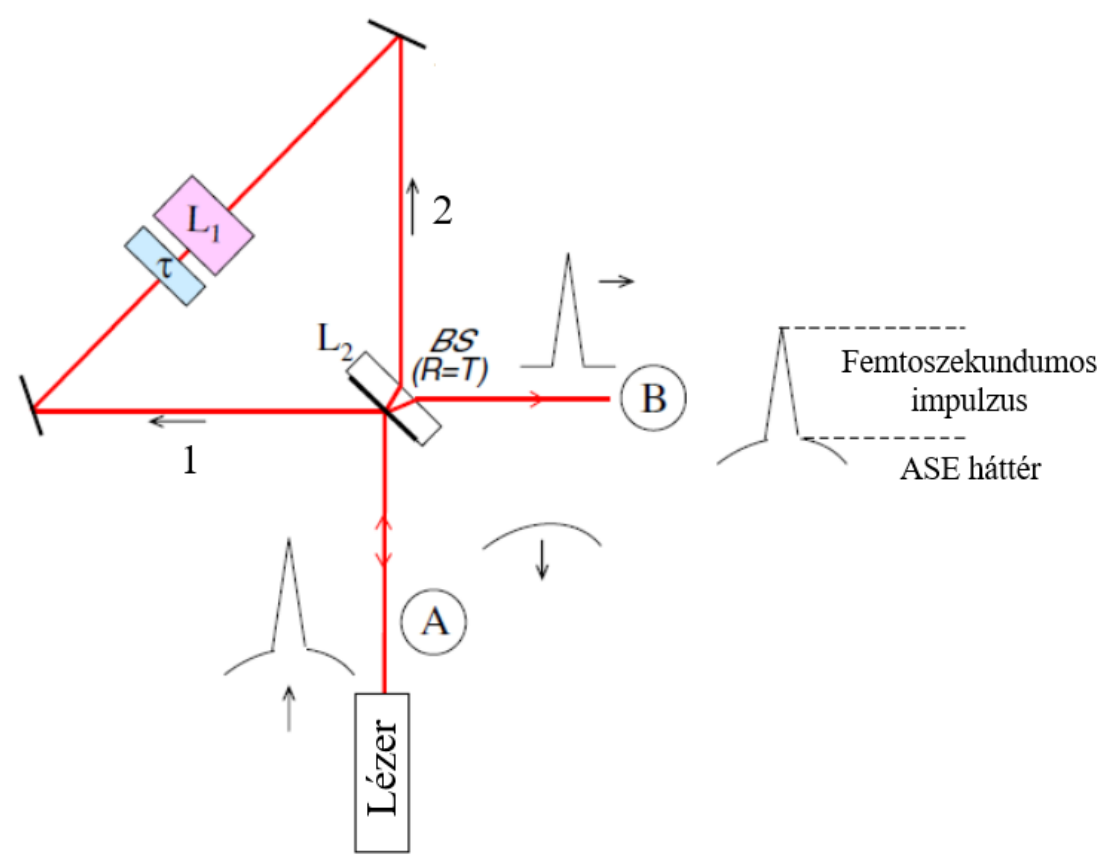

2-5. ábra

A neméineáris Sagnac-interferométer sematikus rajza. (BS: nyalábosztó)[86]

$\mathrm{Az}$ interferométerben az 1-es utat bejáró impulzus kisebb fázistolást szenved a nemlineáris elem által, mint a 2-es utat bejáró impulzus, mert az intenzitását a szürő először $\tau$ szorosára csökkenti $(\tau<1)$. Az interferométerben a 2-es utat bejáró impulzus az eredeti intenzitásának megfelelő fázistolást szenved és az intenzitása csak ezután csökken a $\tau$ szorosára. A jóval alacsonyabb intenzitású zaj (ASE illetve mellékimpulzusok) esetén a fázistolás értéke (és ezek különbsége) elhanyagolható, így ezek az interferométer A pontján lépnek ki (nem jelennek meg a B ponton). A B kimeneten a főimpulzus intenzitása az

$$
I_{B}=\frac{I \cdot \tau}{2}(1-\cos (\Delta \varphi))
$$

összefüggés szerint alakul, ahol $\Delta \varphi$ a két kar közötti nemlineáris fázistolás értéke. Feltéve, hogy a nemlineáris elem vastagsága $L_{1}$ a, nyalábosztó vastagsága $L_{2}$ a fény hullámhossza $\lambda$ a fázistolás értékét az alábbi képlet adja meg.

$$
\Delta \varphi=\frac{\pi \cdot n_{2}}{\lambda}(1-\tau) \cdot\left(L_{1}+L_{2}\right) I
$$

Látható, hogy a fáziskülönbség értéke egyenesen arányos az intenzitással, melynek megfelelő megválasztásával a részimpulzusok között $\pi$ fáziskülönbség biztosítható. Ebben az esetben a $\mathrm{B}$ ponton maximális lesz a főimpulzus intenzitása. 
A módszer kísérleti megvalósítása során az intenzitás csökkentését az interferométerbe helyezett fázismodulációt bevezető tükörpár segítségével változtatták. Az impulzus kontrasztjának harmadrendü autokorrelátorral való mérése során a kimeneten 4 nagyságrendnyi javulást figyeltek meg. A nemlineáris Sagnac-interferométer transzmisszója $\sim 15 \%$ körül volt.

\section{3.d. Nemlineáris ellipszis-rotáció}

Ebben az alpontban ismertetett kontrasztjavító eljárás alapja egy olyan harmadrendü nemlineáris folyamat, amelynek hatására az anyag kettőstörővé válik. Egy olyan esetben, ahol az anyag harmadrendü elektromos szuszceptibilitás tenzorának két nem nulla, független komponense $\left(\chi_{1122}\right.$ és $\left.\chi_{1221}\right)$ van, megmutatható, hogy a jobbra (E-) és balra $\left(E_{+}\right)$cirkulárisan poláros elektromos térerősség komponensek eltérő törésmutatót látnak $\left(n_{+}\right.$illetve $\left.n_{-}\right)$. A két törésmutató közötti különbséget $(\Delta n)$ az alábbi összefüggés írja le:

$$
\Delta n=n_{+}-n_{-}=\frac{3 \chi_{1221}}{n_{0}}\left(\left|E_{-}\right|^{2}-\left|E_{+}\right|^{2}\right)
$$

Az összefüggésben szereplő $n_{0}$ a kristály lineáris törésmutatója. Ennek következtében $z$ út megtétele után a nyaláb polarizációs ellipszise elfordul, ahol az elfordulás szögét a

$$
\Delta \theta=\frac{1}{2} \Delta n \frac{\omega}{c} z
$$

összefüggés adja meg [87].

Ezt a jelenséget rövid impulzusok kontrasztjavítására a 2-6. ábrán látható elrendezéssel használhatjuk fel. A beérkező impulzust először egy $\lambda / 4$-es lemez segítségével elliptikusan polárossá tesszük, majd egy Kepler-teleszkóp fókuszsíkjába valamilyen közeget helyezünk, jellemzően gázt, hogy minimalizáljuk az önfókuszálódást és önfázismodulációt. A fent említett jelenség miatt az impulzus polarizációja elfordul. A teleszkóp után egy második, az elsővel ellentétesre állított $\lambda / 4$-es lemezen halad át a nyaláb és végül a kimeneten egy polarizációs osztón. A kimenő polarizátor úgy kerül beállításra, hogy az eredeti polarizációra merőleges nyalábot átengedje, az azzal megegyezőt pedig reflektálja. Mivel a jóval alacsonyabb intenzitású időbeli háttér a fókuszsíkban nem szenved fázistolást, továbbá ideális beállítás esetén az elrendezés a főimpulzus fázisát $\pi / 2$ értékkel tolja el, ezért a kimeneten a kettő szétválasztható. 


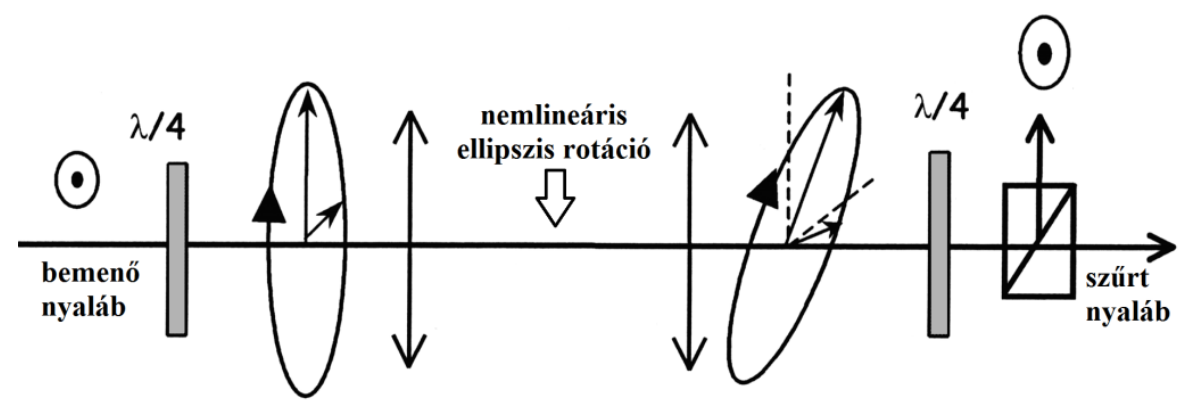

2-6. ábra

A nemlineáris ellipszis-rotációval történö időbeli kontrasztjavitás elvi vázlata [88].

A nemlineáris ellipszis-rotáción alapuló kontrasztjavítást több kutatócsoport is demonstrálta. D. Homoelle és munkatársai egy gázzal töltött üreges hullámvezetőt helyeztek a fenti elrendezés fókuszsíkjába. A bemenő impulzusok energiája $\mu \mathrm{J}$ nagyságrendű volt és 2-3 nagyságrendnyi kontrasztjavulást demonstráltak vele [89]. Az időbeli kontraszt javulásán túl a nyaláb térbeli minőségének javulását is megfigyelték. Ez a térszürő tulajdonság - mint ahogy az később az aktív térszürés tárgyalásakor ismertetem - minden Fourier-síkban végrehajtott nemlineáris szürés jellemzője.

A technika hátránya, hogy energia szerint nem skálázható. A mJ energiaszint esetében már komoly problémát jelentenek a nemlineáris terjedés okozta jelenségek (pl.: önfókuszálódás/filamentáció illetve önfázismoduláció). A. Jullian és munkatársai a fókuszsíkban fellépő nagy intenzitások elkerülésére az eredetileg transzform-limitált 42 fs hosszúságú impulzusok spektrális fázisát másod és harmadrendben modulálták, ezáltal változtatva az impulzushosszat és intenzitást. Nemlineáris közegnek levegöt választottak, a bemenő impulzusok energiája $850 \mu \mathrm{J}$ volt. A legjobb eredményt pozitívan fázismodulált impulzusokkal érték el, amellyel 3 nagyságrendnyi kontrasztjavulást és 25\%-os energia transzmissziót sikerült elérniük [88].

M.P. Kalashnikov és munkatársai 1mJ és 40 fs impulzusparaméterek mellett, ugyancsak azt tapasztalták, hogy pozitívan fázismodulált impulzusokkal lehet a legjobb eredményt kapni, valamint a spektrum így szenvedi el a legkisebb torzítást. A technikával emellett kiváló térbeli minőségü eloszlást nyertek [90].

N G Khodakovskiy [91] ill. N. Smijesh [92] és munkatársaik a nemlineáris ellipszisrotációt az üreges hullámvezető technikával kombinálták. A technika lényege, hogy az impulzus egy gázzal töltött üreges hullámvezetőn halad át, ahol a szál két vége között nyomáskülönbséget létesítve nyomásgradiens alakul ki a szál mentén. Az impulzus a gázban való terjedés során kontrollált önfázismodulációt szenved, ami a spektrum kiszélesedéséhez, 
így rövidebb transzform-limitált impulzushosszhoz vezet. Mivel az üreges szálban egymódusú terjedés valósul meg ezért a nyaláb térbeli tulajdonságai is elvileg ideálisak lesznek. A két technika kombinálásával mindkét csoportnak sikerült 5 fs alatti impulzusidőt és - az intenzitásra vonatkozóan - 50\%-os hatásfokot elérni.

A nemlineáris ellipszis-rotáción alapuló technika komoly hátránya, hogy nagyobb energiájú kompresszált impulzusokra nem alkalmazható. A szürés elött bevezetett fázismoduláció és a szürést követő kompresszálás pedig a CPA sémánál látott koherens háttér megjelenéséhez vezet. További hátrány, hogy a technikával elérhető maximális kontrasztjavulást az elrendezésben használt polarizátorok extinkciós aránya szabja meg, ami legjobb esetben $10^{3}-10^{4}$ értékü.

\section{3.e. Frekvenciakonverzió (aktív térszürés)}

A frekvenciakonverzió egy széles körben alkalmazott nemlineáris folyamat. A frekvenciakonverzión alapuló kontrasztjavítás a többi eljáráshoz képest azzal az előnnyel rendelkezik, hogy míg a többi technika esetében az elérhető kontrasztjavulást valamilyen a nemlineáris folyamattól független technikai nehézség limitálja, addig itt az alapharmonikus és a keltett jel teljesen szeparálható. Másodharmonikus-keltés esetén - mivel a folyamat másodrendü - a kontraszt a négyzetére nő és ezt technikailag is realizálni tudjuk. Dichroikus tükrökkel és/vagy az erősítőláncon való áthaladással az alapharmonikus teljesen kiszürhető.

A rövid impulzusú $\mathrm{KrF}$ rendszerekben eleve frekvenciakonverzióval generálják a magimpulzust az UV tartományban való erősítéshez. Ennek következtében az UV magimpulzusok extrém nagy időbeli kontraszttal rendelkeznek. S. Szatmári és munkatársai mutattak rá arra, hogy a Fourier-síkban végrehajtott frekvenciakonverzió és általánosan bármilyen intenzitás szerint nemlineáris folyamat nemcsak az impulzus időbeli, hanem a térbeli eloszlására is hatással van. Amíg a közeli zónában a nemlinearitás az inhomogenitásokat kiemeli (ezzel általában rontja), addig a távoli zónában bevezetett nemlinearitás lényegesen javíthatja a térbeli tulajdonságokat [93]. Általánosan, egy Fouriersíkban végrehajtott időszürési eljárás (ahol a folyamat az intenzívebb főimpulzust kiemeli az időbeli háttérből) egyben térszürésként is funkcionál, hiszen az intenzitás szerinti szelekció térben is megtörténik. Megfelelő rendezettségű impulzusok esetén a nyaláb intenzívebb, alacsony térfrekvenciás komponensei kiemelődnek. A 2-7. ábra frekvenciakétszerezés során elérhető térszürésre ad példát, ahol a szürés után egy közel szabályos térben Gauss eloszlású nyalábot kapunk. A jelenséget aktív térszürésnek nevezték el. A fentiekre való tekintettel a 
rövid impulzusú $\mathrm{KrF}$ rendszerekben az UV magimpulzusok kiváló időbeli és térbeli minőséggel rendelkeznek.

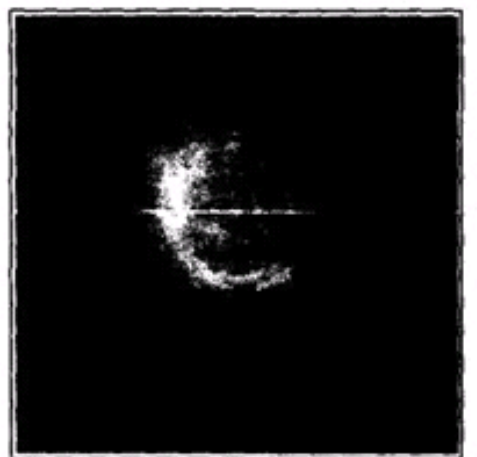

(a)

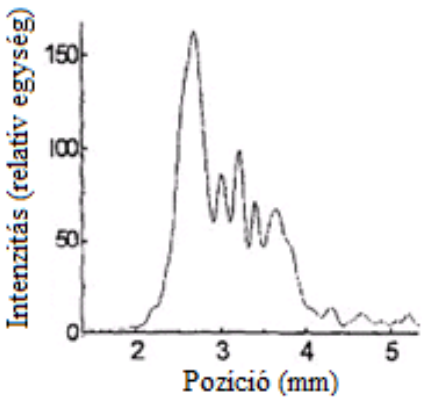

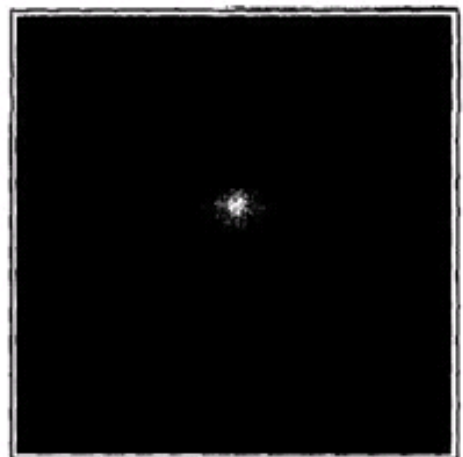

(b)

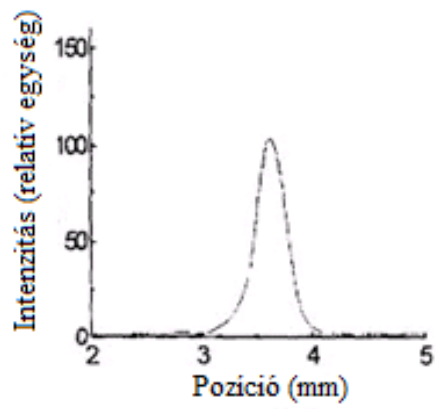

2-7. ábra

Frekvenciakétszerezés térszürő hatásának kísérleti igazolása: közeli zónabeli térbeli intenzitáseloszlás a) a frekvenciakétszerezés elött és b) a frekvencia kétszerezés után [93].

A másodharmonikus-keltéssel való zajszürést az elérhető nagy kontrasztjavulás miatt szilárdtest lézereken is alkalmazták. A. Marcinkevicius és munkatársai az ATLAS-2, ill. ATLAS-10 nevü 2 TW-os (130 fs, 230 mJ), ill. 10 TW-os (180 fs, 1,3J) teljesítményü lézerrendszerek kimenő impulzusainak frekvenciáját kétszerezték KDP nemlineáris kristály segítségével. A frekvenciakonverzió 45\%-os hatásfoka mellett a ns-os időskálán $10^{8}$-ról $10^{16}$ ra ill. $10^{7}$-ről $10^{14}$-re becsülték az intenzitáskontraszt javulását. Ezzel a másodrendű folyamat által biztosított maximális kontrasztjavulást demonstrálták [94].

D. Hillier és munkatársai az Orion 500J-os, 500 fs-os és 1054 nm központi hullámhosszon működő lézerrendszer impulzusait frekvenciakétszerezték. A kétszerezés energiatranszmissziója $20 \%$ volt, az intenzitáskontraszt pedig 6 nagyságrendet javulva elérte a $10^{14}$ értéket [95].

A frekvenciakonverzión alapuló zajszürés nagyon hatékony kontrasztjavítást eredményez. Ugyanakkor azon túlmenően, hogy szükségszerüen a frekvencia 
megváltozásával jár, magas hatásfokot csak relatíve hosszú (>100fs) impulzusokra biztosít. A rövid impulzusidőből fakadó nagy spektrális sávszélesség miatt, az alap és másod harmonikus csoportsebesség diszperziója és a csoportsebességük közötti különbség a fázisillesztést csak nagyon rövid kristályhosszakra teszi lehetővé, ami a konverziós hatásfokot erősen limitálja. Egy bizonyos intenzitásszint felett a spektrális torzítással és a nemlineáris kristály roncsolódásával is számolni kell.

\section{3.f. A koherens kontraszt javítása}

Ahogy azt ezen fejezet elején ismertettem a CPA sémát használó szilárdtest lézerek időbeli háttere egyrészt a ns-os skálán mérhető inkoherens ASE-ból, másrészt pedig a néhány 10 ps-os skálán mérhető spektrális torzítások illetve szórás okozta koherens talpakból áll. Az utóbbi eredetére és csökkentésére is számos kutatás irányult, hiszen a koherens kontraszt jellemzően egy 20 ps-os skálán exponenciálisan $10^{4}-10^{9}$-re csökkenő mellékimpulzust jelent, ami rendkívül nagy hatással lehet az alkalmazásokra.

C. Hooker és munkatársai a 20 TW-os titán-zafír rendszerük esetében kutatták a koherens kontraszt eredetét. Megfigyelésük szerint, ehhez az időbeli háttérhez a kompresszáláshoz használt rácson fellépő szórás is hozzájárul. A kompresszor rácsát egy jobb optikai minőségüre cserélve a koherens kontraszt értékét 1 nagyságrenddel sikerült javítaniuk [96].

D. Kaganovich és munkatársai a koherens talpak eredetét a rendszerben lévő optikák és az erősítés során fellépő spektrális beszükülésnek tulajdonították [97]. Mint ismeretes a frekvencia képben történő éles vágás az időbeli eloszlásban mellékimpulzusok és lecsengő talpak megjelenéséhez vezet (logaritmikus skálán szemlélve). A probléma hasonló az adatfeldolgozásban használt mintavételi ablakok kérdésköréhez. Minél élesebb vágást vezetünk be a frekvencia képben, annál nagyobb amplitúdóval jelennek meg talpak az időbeli képben. Ezen talpak csökkentésére egy interferometrián alapuló eljárást javasoltak, amelynek lényege, hogy egy Michelson-interferométerben kettéosztott impulzust változtatható késleltetés mellett egyesítenek. Mint ismert két azonos $\mathrm{A}_{0}$ amplitúdójú, $\tau_{\mathrm{L}}$ hosszúságú és $\omega_{0}$ központi frekvenciájú, egymáshoz képest $\tau_{\mathrm{D}}$ idővel késleltetett impulzus szuperpozíciója az

$$
|\tilde{A}(\omega)|^{2}=\frac{A_{0}^{2}}{4} \tau_{L}^{2} \exp \left(-\frac{\omega^{2} \tau_{L}^{2}}{2}\right)\left\{1+\cos \left[\left(\omega+\omega_{0}\right) \tau_{D}\right]\right\}
$$


spektrális intenzitással írható le. $\tau_{\mathrm{D}}$ értékét úgy megválasztva, hogy az első minimum éppen az eredeti impulzus spektrum szélére essen, egy olyan vágást vezetünk be a frekvencia képben, amely kisebb amplitúdójú talpakat eredményez. Ezzel a kísérleti elrendezéssel 1 nagyságrenddel sikerült javítaniuk a koherens kontraszt értékén.

\section{3.g. Kereszt-polarizált hullámkeltés}

A kereszt-polarizált hullámkeltés (Cross-polarized wave generation, XPW) a harmadrendü szuszceptibilitás tenzor valós részének anizotrópiáján alapuló nemlineáris folyamat. Ezen jelenség esetében két nemlineáris kaszkád folyamat (másodharmonikus- és különbségi frekvencia keltés) hatására egy, a keltő hullámmal azonos frekvenciájú, de arra merőleges polarizációjú hullám keltődik $\left(\omega^{\perp}=\omega^{\|}+\omega^{\|}-\omega^{\|}\right)$. A folyamat előnye a harmonikus keltéssel szemben, hogy a keltő és keltett jel azonos frekvenciájú, így a fázis és csoportsebesség illesztettség automatikusan teljesül. A telítődés alatti intenzitások esetén a kereszt-polarizált hullámkeltés hatásfokát az

$$
\eta=\frac{I_{X P W}}{I_{0}}=\frac{2}{\varepsilon_{0} c n}\left[(\sigma / 4) \gamma_{0} I_{0} \sin (4 \beta) L\right]^{2}
$$

összefüggés írja le, ahol $I_{X P W}$ a keltett, $I_{0}$ pedig a beeső hullám intenzitása, $\gamma_{0}=$ $6 \pi \chi_{x x x x}^{(3)} / 8 n \lambda, \beta$ a kristály [001] tengelye és a nyaláb polarizációs síkja által bezárt szög, $\mathrm{n}$ a kristály törésmutatója, $\lambda$ a fény hullámhossza, c a fénysebesség, $L$ a kristály hossza, $\sigma$ pedig a harmadrendủ szuszecptibilitás anizotropiáját jellemző mennyiség $\sigma=\left[\chi_{x x x x}^{(3)}-\left(\chi_{x x y y}^{(3)}+2 \chi_{x y y x}^{(3)}\right)\right] / \chi_{x x x x}^{(3)}$. Az összefüggésből látszik, hogy az anizotropia mértékének növekedésével nő a konverziós hatásfok. Egy bizonyos intenzitás felett a hatásfok $33 \%$-os értéknél telítődik. A kísérleti elrendezésekben általában $\mathrm{BaF}_{2}$ vagy $\mathrm{CaF}_{2}$ kristályt használnak.

N. Minkovski és munkatársai demonstrálták először az effektust 10\%-os konverziós hatásfokkal [98], majd a további kutatások eredményeképp a kristály orientációjának változtatásával sikerült 30\%-os hatásfokot elérni [99].

A technika alkalmazása rövid impulzusok kontrasztjavítására abból áll, hogy két keresztezett polarizátor közé helyezünk egy konfokális teleszkópikus elrendezést, amelynek közös fókuszsíkjában van elhelyezve a nemlineáris kristály. Mivel a nemlineáris jelenség a 
fókuszsíkban történik ezért térszürési tulajdonsága is kihasználható az elrendezésnek. A folyamat harmadrendü függése miatt az impulzusidő $\sqrt{3}$-adára csökken.

Az XPW technika az egyik legelterjedtebb eljárás nagyintenzitású lézerek kontrasztjavítására. A technika relatíve alacsony hatásfoka és energia szerinti limitált skálázhatósága miatt az elrendezést DCPA rendszerekbe két erösítési fokozat közé integrálták. V. Chykov és munkatársai egy 50 TW csúcsteljesítményü rendszerben alkalmazva az XPW technikát 10\%-os hatásfok mellett 3 nagyságrenddel, $10^{11}$ értékre tudták javítani az intenzitáskontrasztot a ns-os időskálán. [100]. M.P. Kalashnikov és munkatársai egy $100 \mathrm{TW}$-os rendszerbe integrálták az XPW-t és ugyancsak $10^{11}$ intenzitáskontrasztot demonstráltak a ns-os skálán. A kísérlethez $\mathrm{CaF}_{2}$ kristályt alkalmaztak amivel 7\%-os konverziós hatásfokot tudtak elérni [101].

A. Ricci és munkatársai az XPW technikát a HCF technikával egyesítve vezettek be egy elrendezést, amely hatékony tér- és időszürés mellett az impulzusidőt is (> 2-es faktorral) csökkentette. Az elrendezésben először az üreges hullámvezetőn halad át az impulzus majd pedig az XPW-hez használt kristályon. Az ideális impulzusidőhöz a bemenő impulzus spektrális fázisát előre modulálni kell. Az elrendezés energia transzmissziója 20\% volt, de az impulzusrövidülés miatt a teljesítményre értelmezett hatásfok $>40 \%$-nak adódott [102].

Az XPW technikát számos nagyintenzitású lézerrendszerben használják és alkalmazása egyre népszerűbb [103]. Az XPW technika által elérhető kontrasztjavulást - a korábban bemutatott példákhoz hasonlóan - az elrendezésben használt polarizátorok extinkciós aránya szabja meg, ami nem haladja meg a 3-4 nagyságrendet. Az XPW technika hártánya, hogy energia tekintetében nem skáláztható, multi-mJ-os energiájú impulzusok esetén a kristályban fellépő spektrális és térbeli torzítások jelentőssé válnak. Az XPW technikát eddig nem demonstrálták nagyintenzitású $\mathrm{KrF}$ lézerek impulzusaira. A technika alkalmazhatósága azért kérdéses, mert a $\mathrm{KrF} 248$ nm-es a hullámhosztartományán nem léteznek nagy extinkciós arányú polarizátorok, továbbá a folyamat által megkövetelt intenzitás mellett az UV-ben a kristály nemlineáris abszorpciója is megjelenik [104].

\section{3.h. Plazma tükör}

$\mathrm{Az}$ egyik legelterjedtebb módszer a nagyintenzitású impulzusok kontrasztjának javítására a plazma tükör technika, amit H. Kapteyn és munkatársai vezettek be [105]. A technika a lézerimpulzus által keltett plazma tükörszerü reflexiójának jelenségét használja ki az előimpulzus és a főimpulzus szeparálására. Egy sík üveg céltárgyon egy lézerimpulzus 
által keltett plazmában az elektronok szabadon és nagy sürüséggel helyezkednek el. Ez a tulajdonság nagyban hasonlít a fémek elektronszerkezetére, emiatt a sürü plazma fémszerü reflexióval rendelkezik. Ez az állapot mindaddig áll fenn, amíg a plazma tágulása a reflexió ideje alatt nem válik összemérhetővé a fény hullámhosszával. Szub-ps hosszúságú impulzusok esetében ez a feltétel könnyen teljesíthető, így megfelelő kísérleti paraméterek mellett elérhető, hogy az előimpulzus az ionizációs küszöb alatt maradva áthaladjon a céltárgyon, míg a főimpulzus felfutó éle plazmát keltsen a céltárgy felszínén, amely utána reflektálja az impulzus további részét. Egy ilyen elrendezésben a kontrasztjavulás érétkét a nagyjelü és a kisjelü reflexió hányadosa szabja meg. A kisjelü reflexió értékét a céltárgyra párologtatott antireflexiós réteggel lehet minimalizálni. A plazma tükör egyik legnagyobb előnye, hogy a nagyjelü reflexió magas értéke esetén kis energiaveszteséggel jár és, hogy nagy energiákra jól skálázható. A kisjelü reflexióra vonatkozó korlátok miatt azonban a kontrasztjavulás értéke nem haladja meg a 2-3 nagyságrendet.

Ch. Ziener és munkatársai az impulzushossz, a beesési szög és a céltárgyra eső intenzitás változtatása mellett $250 \mathrm{~mJ}$ energiájú valamint 90 és 500 fs hosszúságú impulzusokra demonstrálták a plazma tükör müködést. Kísérleteik során azt tapasztalták, hogy $\sim 10^{14} \mathrm{~W} / \mathrm{cm}^{2}$ intenzitás felett kezdett el növekedni a felület reflexiója, majd egy - az impulzushossztól és beesési szögtől függő - 65-80\%-os maximum után meredeken esni kezdett és a mérési pontok szórása is megnőtt. [106] A legjobb eredményt $6^{\circ}$-os beesési szög és 90 fs impulzushossz mellett érték el, ekkor a maximális reflexió érétke meghaladta a 80\%ot. Az ehhez tartozó intenzitás valamelyest kisebb, mint $10^{16} \mathrm{~W} / \mathrm{cm}^{2}$ volt. C. Rödelnek és munkatársainak a tükörként használt céltárgy antireflexiós rétegének körültekintő megválasztásával a kisjelü reflexiót sikerült $0,1 \%$ érétken tartani. A technika ismétlési frekvenciája pedig $10 \mathrm{~Hz}$ volt. A maximálisan elért $\sim 80 \%$ körüli reflexióval 3 nagyságrendnyi kontrasztjavulást tudtak elérni a ns-os skálán, így a 85 fs és $800 \mathrm{~mJ}$ paraméterü lézerrendszer $10^{11}$ kontraszttal rendelkezett. A kontraszt növekedésének kritikus hatását szilárdtest felületén keltett magasharmonikusok tulajdonságaival is demonstrálták [107].

A. Lévy és munkatársai az elérhető kontrasztjavulás kiterjesztése érdekében egy olyan elrendezést fejlesztettek ki ami egymás után két plazma tükröt tartalmaz. A kísérletben használt 10 TW csúcsteljesítményü rendszerük kontrasztját 4 nagyságrenddel javították $10^{10}$ értékre. A szürési elrendezés kimenetén a kezdeti energia 50\%-a jelent meg [108]. 
I.B. Földes és munkatársai az SZTE HILL laboratóriumban végzett korábbi kísérletek során a plazma tükör müködést nagyintenzitású $\mathrm{KrF}$ lézerimpulzusokra demonstrálták. Az első kísérletek alkalmával elért $\sim 35 \%$-os reflexiót (600 fs és $45^{\circ}$-os beesési szög) a beesési szög ideális megválasztásával sikerült 50\%-ra növelni [36, 37].

A plazma tükör technika a magas energia hatásfoka miatt az egyik legelterjedtebb kontrasztjavító eljárás, amit legtöbbször a lézerrendszer kimenetén alkalmaznak [109-114]. A legnagyobb (97\%-os) plazma tükör reflexiót G. Scott és munkatársai érték el akik, egy néhány ps-mal előbb érkező előimpulzussal változtatták a plazma skálahosszát [113]. Az elérhető kontrasztjavulás értékét azonban a kisjelü reflexió véges értéke behatárolja és csak többszöri alkalmazással lehet elérni tekintélyes kontrasztjavulást. Ez ugyanakkor jelentősen növeli az energiaveszteséget is. A plazma tükör hátránya, hogy a céltárgy felületének roncsolódása miatt minden lövés friss céltárgyfelületet kíván, ami nagyobb ismétlési frekvenciák esetében technikai nehézségeket eredményez. A technika problémája, hogy a maximális reflexió jól meghatározott, limitált intenzitást kíván. Nagyobb csúcsteljesítményü impulzusok esetén a megkövetelt foltméret lényegesen nagyobb a fókuszsíkbelinél, aminek okán a céltárgyat fókuszsíkon kívül kell elhelyezni. Ekkor az impulzus által keltett plazma nem megfelelő optikai minősége jelentős fázisfront torzulásokat eredményezhet a nyalábban. A technika elönye hogy széles hullámhossztartományban használható és relatíve egyszerü a kísérleti elrendezés.

\section{3.i. Nemlineáris Fourier-szürés}

A nemlineáris Fourier-szürés elve egy fókuszsíkban bevezetett nemlineáris fázis/amplitúdómoduláció okozta térbeli szelekción alapszik. A szürési elv bevezetését és első kísérleti demonstrációját $\mathrm{S}$. Szatmári és munkatársai végezték, amelyhez munkámmal én is hozzájárultam [38]. Az általuk javasolt elrendezés egy konfokális teleszkóp közös fókuszsíkjában lévő nemlineáris elemből, valamint a bemeneten elhelyezett gyürü alakú apertúrából és a kimeneten elhelyezett inverz apertúrából áll (2-8. ábra). A kis intenzitású időbeli háttér lineáris terjedés esetén - a geometriai optika határain belül - teljesen kiszürődik az inverz apertúra pár által. A gyürü alakú nyalábra a Fourier-síkban bevezetett, intenzitásfüggő nemlineáris moduláció a nyaláb irány szerinti tulajdonságainak megváltozásához vezet. Az intenzív föimpulzus a nemlineáris modulációnak köszönhetően megváltozott közeli zónabeli térbeli eloszlással fog rendelkezni, ezáltal a kilépő apertúrán véges transzmisszióval kilép. 


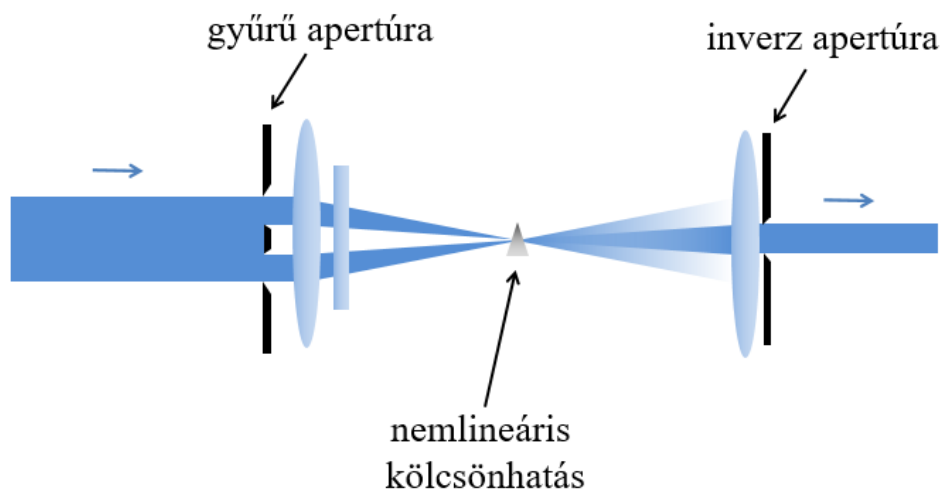

2-8. ábra

A nemlineáris Fourier-szürés sematikus rajza.

A Fourier-síkban bekövetkező nemlineáris amplitúdómoduláció és fázismoduláció lehetőségét is megvizsgálták. A numerikus modellezések szerint egy gyürü alakú nyaláb Fourier-síkjában való intenzitás függő amplitúdómoduláció esetén - amely történhet például plazma tükör segítségével - az eredeti nyaláb energiájának <15\%-a esne a kimeneten a gyürü közepébe (ideális méretarányokkal bíró gyürü esetén), ahol nem számoltunk a plazma tükör által okozott energiaveszteséggel. A számolás során a Fourier-síkbeli első mellékcsúcs 25-ös faktorral való elnyomását feltételezték a középső csúcshoz képest. Az eljárás amplitúdómoduláción alapuló változata ugyan elméletileg kisebb hatásfokkal bír, de a kísérleti megvalósításhoz szükséges plazma tükörrel való kombináció extrém magas kontrasztjavulást eredményezhet. Ezen okoknál fogva az elrendezés kísérleti úton való vizsgálata előremutató.

Jóval kedvezőbb az energiahatásfok abban az esetben, ha fázismodulációt vezetünk be a nyaláb Fourier-síkjában. A számítások szerint ideális esetben - ha a Fourier-síkbeli eloszlás középső maximuma és az első mellékmaximum között $\pi$ fázistolást vezetünk be - a kimeneten az energia $>50 \%$-a jelenik meg optimális méretarányokkal rendelkező gyürü esetén. A modellezés szerint egyúttal a nyaláb magas térfrekvenciás komponensei is kiszürődnek, így térszürésként is funkcionál. A nemlineáris fázismoduláció kísérleti bevezetését egy nemesgáz felhőben az impulzus felfutó éle által keltett plazmában való terjedés szolgáltatta. A plazma (1-nél kisebb) törésmutatója az ionizációs fok függvénye, azaz a térbeli intenzitásváltozás egyúttal térbeli törésmutató modulációt is okoz. 


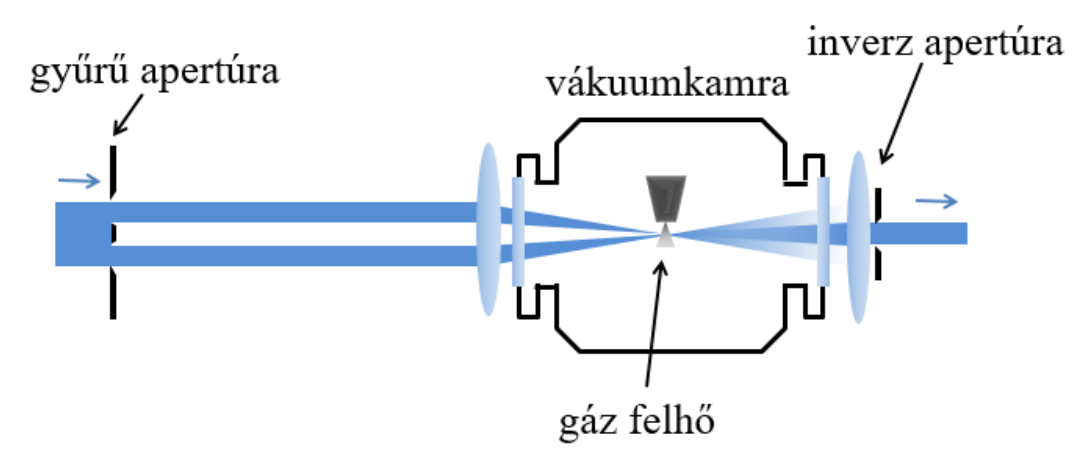

2-9.ábra

A fókuszsíkban bevezetett fázismoduláción alapuló nemlineáris Fourier-szürés kísérleti megvalósitása.

A kísérleti demonstráció (2-9. ábra) során rövid impulzusú $\mathrm{KrF}$ lézerrendszer 500 fs hosszú impulzusait fókuszálták egy vákuumkamrában elhelyezett Ar gázfelhőbe. A gyürü alakú nyaláb energiája $3 \mathrm{~mJ}$ volt. A kimeneten az energia $>40 \%$-a jelent meg és az intenzitáskontraszt 3 nagyságrendnyi javulását detektálták. A kísérlet során a nagyobb kontrasztjavulás elérése érdekében az inverz apertúra pár úgy volt elhelyezve, hogy a fókuszáló lencse a bemenő apertúrát a kimenő apertúra síkjába képezze, ezáltal minél pontosabban kiszürhető legyen az időbeli háttér (esetünkben az ASE). A kísérleti tapasztalat szerint a kimeneten mérhető időbeli háttér (ami a bemenő háttérhez képest 3 nagyságrenddel kisebb) függetlennek bizonyult a fókuszsíkban lezajló nemlineáris folyamattól, hiszen akkor is mérhető volt, ha nem volt gázfelhő a vákuumtérben. A szerzők a kimeneten mérhető háttér eredetét parazita reflexiókban, szórásjelenségben, illetve az optikai leképezés alacsony térbeli kontrasztjában azonosították.

\subsection{Célkitüzések}

A nagy intenzitású elektromágneses terek alkalmazásának legfontosabb feltétele a rövid impulzusok magas tér- és időbeli minősége. Bár az elmúlt időszakban számos kontrasztjavító eljárást vezettek be az impulzusok időbeli tisztasága még mindig nem elegendő a jelenleg rendelkezésre álló impulzusok csúcsintenzitásának figyelembe vételével. Számos fény-anyag kölcsönhatási kísérlet esetén előnyösebb a rövid hullámhosszúságú impulzusok használata. $\mathrm{Az}$ ultraibolya tartományban rövid impulzusú $\mathrm{KrF}$ excimer lézerrendszerekkel lehet a legnagyobb intenzitást elérni. A nagyintenzitású KrF lézerrendszerek kontrasztjavítására korábban sikeresen alkalmazták a plazma tükör technikát amivel 2 nagyságrend kontrasztjavulást és 50\%- ot megközelítő reflexiót értek el. Ugyancsak nagyintenzitású 
ultraibolya impulzusok kontrasztjának javítására vezették be a nemlineáris Fourier-szürés technikát, amellyel 3 nagyságrendnyi kontrasztjavulást és 40\%-os energia transzmissziót értek el.

A kutatásaim során célul tüztem ki a plazma tükör reflexiójának növelését ultraibolya rövid impulzusokra. Ezen felül célom volt, hogy megvizsgáljam az elérhető reflexió impulzushossztól való függését, továbbá a reflexió hatását a nyaláb fókuszálhatóságára.

Célul tüztem ki a nemlineáris Fourier-szürés kontrasztjavítását limitáló optikai leképezés kvantitatív elméleti modellezését, a leképezés térbeli kontrasztjavításának vizsgálatát illetve egy nagyobb kontrasztjavulást biztosító nemlineáris Fourier-szürési elrendezés bevezetését.

Célul tűztem ki a nemlineáris Fourier-szürési elrendezés részét képező optikai leképezés javításának és a technikával elérhető kontrasztjavulás növelésének kísérleti demonstrációját, valamint a nemlineáris Fourier-szürésnek a nyaláb térbeli tulajdonságaira gyakorolt hatásának vizsgálatát.

A kutatásaim végső céljaként tüztem ki egy a nemlineáris Fourier-szürőt magában foglaló nagyintenzitású és nagy kontrasztú ultraibolya $\mathrm{KrF}$ lézerrendszer megépítését és impulzusainak karakterizálását. 


\section{Tudományos eredmények}

\subsection{Plazma tükör ultraibolya impulzusokra vonatkozó reflexiójának növelése}

A plazma tükör jelenség technikai egyszerüségénél fogva az egyik legjobb jelölt ultraibolya impulzusok kontrasztjának javítására. Rövid lézerimpulzusok plazma tükör technikával történő időbeli szürésénél az elérhető kontrasztjavulást a nagyjelü és a kisjelü reflexió viszonya határozza meg. Amíg a kis jelü reflexiót a céltárgyként használt anyag illetve az arra felvitt anti-reflexiós réteg minősége szabja meg, addig a nagyjelü reflexiót több nemlineáris folyamat befolyásolja. A szakirodalomban korábban publikált eredményekböl látható, hogy az impulzus hossza, időbeli alakja, polarizációja és térbeli tulajdonsága jelentős befolyással bírnak az elérhető reflexióra. A technikát rövid ultraibolya impulzusok időbeli szürésére direkten a közeli zónában, vagy amplitúdómodulációra a távoli zónában, a nemlineáris Fourier-szürés részeként is lehet alkalmazni. Ugyanakkor az ultraibolya impulzusok nagyobb behatolási mélysége és abszorpciója nagyobb energiaveszteséget eredményez. Bár az UV impulzusokra történő első plazma tükör kísérletek eredményei bíztatók voltak [36, 37], mindenképp szükséges lenne magasabb reflexió elérése, valamint a nyaláb térbeli minőségének (jó fókuszálhatóságának) megőrzése. A következőkben a rövid ultraibolya impulzusok plazma tükör technikával történő időbeli szürésével kapcsolatos tudományos eredményeimet tekintem át [115].

\section{1.a. Plazma tükör reflexiójának vizsgálata 500 fs hosszúságú impulzusokkal}

A plazma tükörrel való kontrasztjavítás kísérleti megvalósításához a 3-1.ábrán sematikusan látható festék-excimer lézerrendszert használtam [68]. Ezen lézerrendszerben az ultraibolya tartományba való konverziót követően a rövid impulzus a kezdeti 15-20 $\mu \mathrm{J}$ energiáról két erősítési átmenetben $10 \mathrm{~mJ}$ energiára erősödik 1-10 Hz es ismétlési frekvencia mellett. A KrF excimer erősítőt döntött tengelyü [78] elrendezésben használtam. Ezen elrendezés használatát az indokolja, hogy ekkora energia és impulzushossz mellett (500fs) már kis nyílásszögü (f/30) fókuszálással is stabilan elérhető $>10^{15} \mathrm{~W} / \mathrm{cm}^{2}$ intenzitás, amely a korábbi KrF lézerimpulzusokkal történő plazma tükör reflexió mérések tanulsága szerint elegendő a maximális reflexió eléréséhez [36]. Ugyanakkor az excimer erősítőkön való erősítési átmenetek kis száma és a nyalábátmérő viszonylag kis $(\sim 2 \mathrm{~cm})$ értéke kedvezö intenzitáskontrasztot $\left(\sim 10^{10}\right)$ és kiváló fókuszálhatósági tulajdonságot biztosít. 


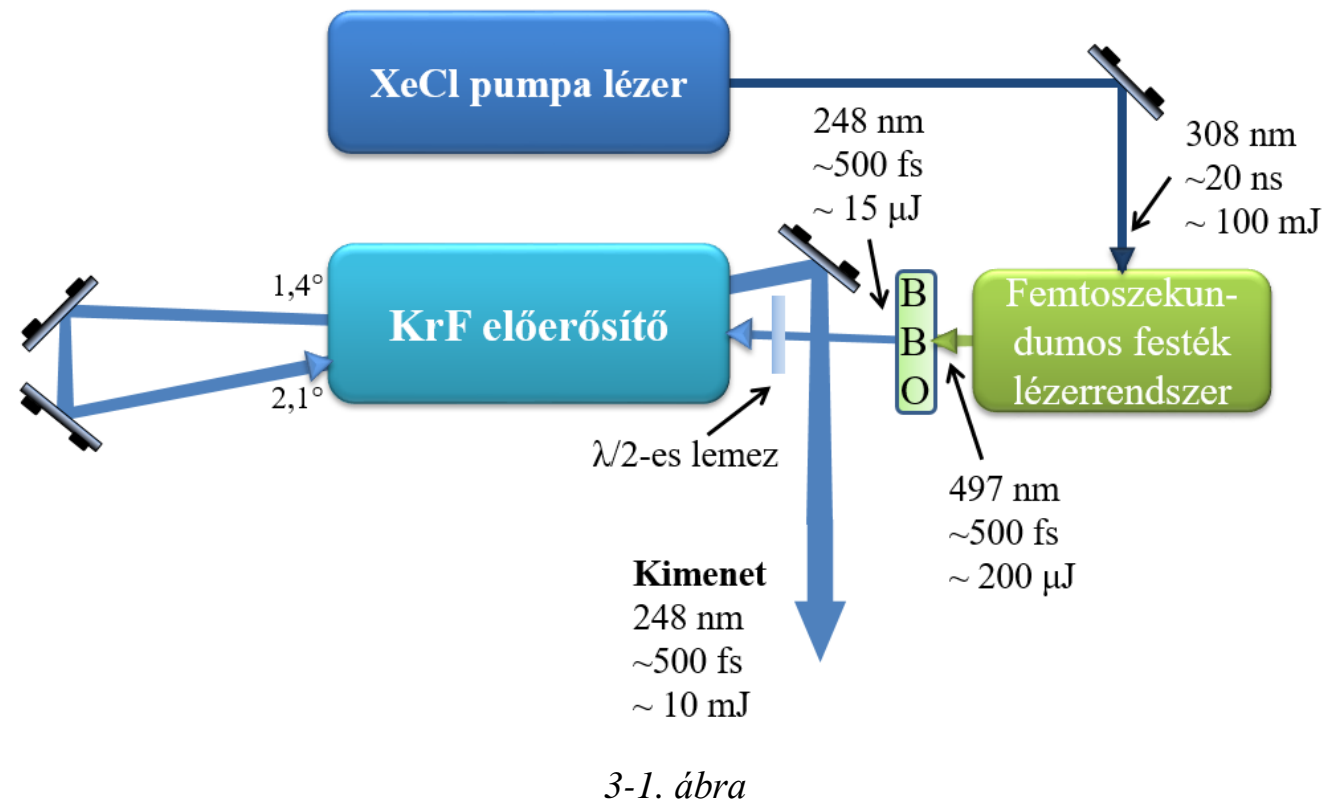

Plazma tükör reflexiójának vizsgálatához használt festék-excimer lézerrendszer sematikus rajza.

A plazma tükör intenzitásfüggő reflexiójának vizsgálatához a 3-2. ábrán látható mérési elrendezést alkalmaztam. A kísérlethez használt céltárgy 50×50x3 mm dimenziójú sík kvarcüveg volt, amelynek egyik fele $248 \mathrm{~nm}$-es hullámhosszra és $0^{\circ}$-os beesési szögre tervezett anti-reflexiós réteggel volt bevonva. A levegő ionizálása által okozott intenzitás letörés elkerülése érdekében a céltárgy egy vákuumkamrában volt elhelyezve, ahol számítógép által vezérelt mechanika végezte a céltárgy $\mathrm{x}-\mathrm{y}$ síkban (a céltárgy síkjában) való mozgatását. Minden egyes impulzushoz friss céltárgy felületet használtam, egy céltárgyra 3000 lövés fért rá. A kamrát elővákuum és turbomolekuláris szivattyú szívta vákuumra, amelynek eredményeképp a kamrában lévő nyomás jellemzően a $10^{-5}$ mbar értéket közelítette meg. A vákuumkamra kialakítása (a bemenő és kimenő ablak távolsága) a céltárgyra vonatkozó $12^{\circ}$-os beesési szöget tett lehetővé. 


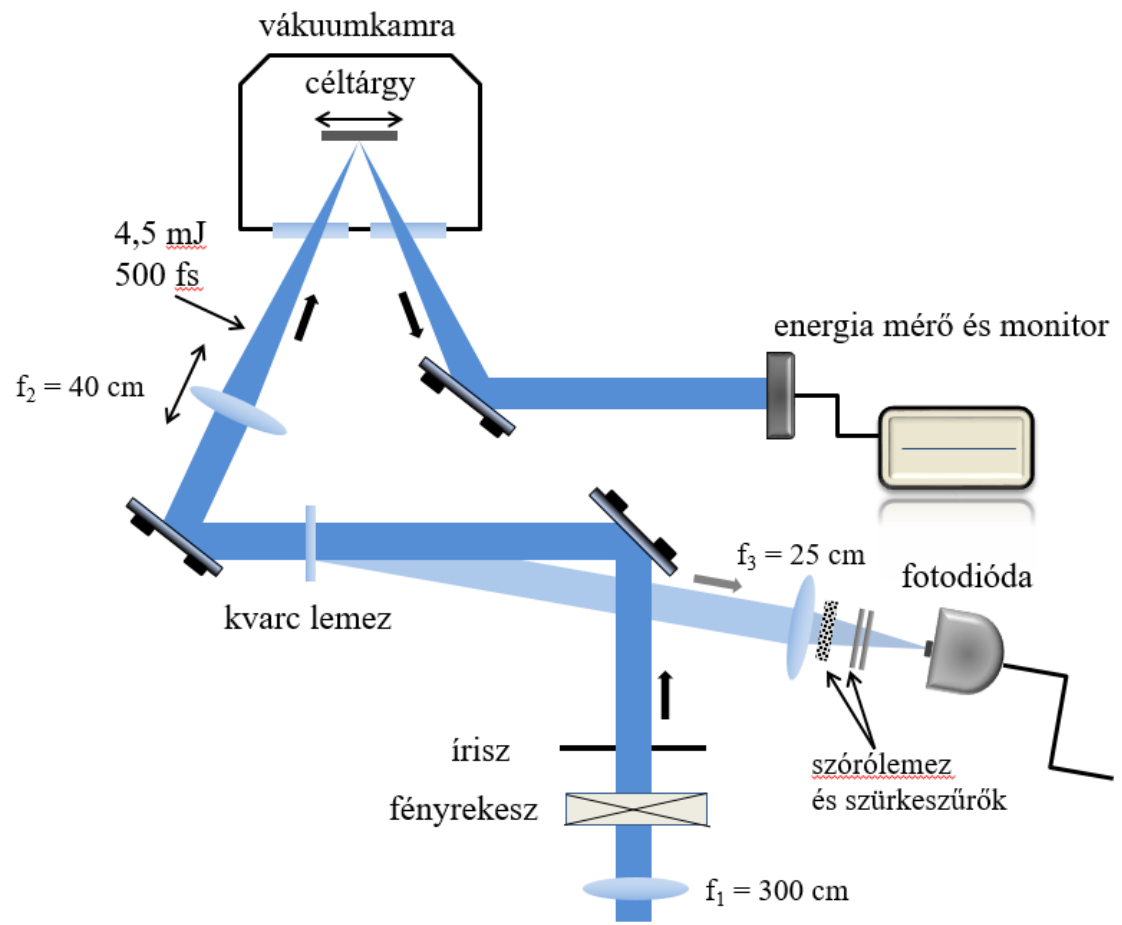

3-2. ábra

A plazma tükör reflexiójának méréséhez használt kisérleti elrendezés sematikus rajza.

A lézerrendszer kimenetétől a kísérleti asztalig a nyaláb több méter utat tett meg. Mivel a levegő mozgása miatt elszenvedett nyalábtorzítások a megtett úttal, illetve a nyalábátmérővel hatványozottan skálázódnak, ezért a lézerrendszer kimenetén egy $\mathrm{f}_{1}=300$ cm-es lencsével enyhén összetartóvá tettem a nyalábot. A céltárgyra egy $\mathrm{f}_{2}=40 \mathrm{~cm}$-es lencsével fókuszáltam a közel téglalap alakú 1,5x1,2 cm-es nyalábot. (A nyalábnyak és a lencse távolsága 37 cm-nek adódott.) A fókuszálás f-száma ( 30$)$ elég kicsi a kívánt intenzitás eléréséhez (diffrakció-limitált esetben), ugyanakkor elég nagy ahhoz, hogy a lencsehibák ne okozzanak számottevő intenzitáscsökkenést.

A kisüléssel pumpált excimer erősítők néhány másodperces memóriával rendelkeznek a kisülés alakját illetően, ezért az impulzus térbeli alakjára és energiájának stabilitására pozitív hatással lehet az, ha egy folyamatos müködés sokadik impulzusát választjuk ki a méréshez. Az impulzusok szelektálását ezért egy fényrekesszel szabályoztam.

A bemenő nyaláb energiájának monitorozásához egy kvarclappal csatoltam ki a nyaláb egy részét, amelyet gyüjtőlencse segítségével egy $\mu$ s időállandójú fotodiódára bocsájtottam. A dióda maximális jelszintjét egy ezen célra fejlesztett hardver és szoftver egység dolgozza fel és rögzíti, ahol a dióda és a számítógép közötti kommunikáció optikai szálon történik, ezáltal kiszürve a nagyfeszültségü áramkörök által pumpált excimer lézerek elektromos zaját 
[116]. Minden méréssorozat előtt a dióda jelét 30 db impulzus energiájának a mérésével hitelesítettem a kamra bemenő ablaka előtt.

A céltárgyról reflektált nyaláb energiáját egy GENTEC QE50PL-S-MD-D0 energiamérő fej segítségével mértem. A reflexió értékének számításakor figyelembe vettem a vákuumkamra ablakai által okozott veszteséget. A vákuumkamra ablakok az előzetes mérések szerint $\mathrm{T}=85 \%$-os transzmisszióval rendelkeznek a rövid jelre nézve. A céltárgyra eső intenzitást a céltárgy és a fókuszáló lencse távolságával változtattam.

Az elérhető nagyjelü reflexió szempontjából kulcsfontosságú a nyaláb térbeli eloszlása a céltárgy felületén. A nyaláb fázisfrontja tartalmazhat olyan torzításokat, amelyeket a lézerrendszer elemei vezettek be (ez jellemzően asztigmia). Ezen torzítások a lencse megfelelö tengely körüli döntésével részben korrigálhatók. A fókuszáló lencsét ezért egy két tengely körül dönthető tartóra helyeztem, a fókuszfolt alakját pedig egy CCD kamerával vizsgáltam. A fókuszfolt vizsgálatához a fókuszáló lencse után egy terelőtükröt helyeztem be. A fókuszsíkot egy f=5 cm-es lencsével képeztem le 14,4-szeres nagyítással egy Hamamatsu C7040 típusú CCD kamerára. A leképezés nagyítását a kamera pixelméretéhez ( 24 x $24 \mu \mathrm{m})$ illesztettem. A CCD kamera telítésének elkerülése érdekében a lencse után közvetlen egy nagy reflexiójú (R>99,5\%) kvarc hordozójú dielektrikum tükörrel, továbbá szürkeszürökkel $(\mathrm{OD}=3$ és $\mathrm{OD}=2)$ csökkentettem a fény intenzitását. A CCD kamera elé egy $20 \mathrm{~cm}$ hosszú csövet és egy $3 \mathrm{~mm}$ átméröjü tűlyukat helyeztem a külső zavaró fények kiszürésére.

A fókuszáló lencse durva beállítása után kapott fókuszsíkbeli eloszlásról készített felvétel a 3-3a. ábrán látható. Megfigyelhető, hogy az állandó középső fókuszfolt mellett asztigmiás hibára emlékeztető mellékmaximumok is feltűnnek. Ezek alakja nagyjából konstans, a csúcsok nagyságának aránya azonban változó volt. A korábbi kísérleti tapasztalatok alapján a lövésről lövésre megfigyelhető véletlenszerü változások a levegő áramlása miatt elszenvedett torzításokhoz köthetők. A fókuszeloszlásban lévő állandó struktúrák jól kompenzálhatók a lencse döntésével. 

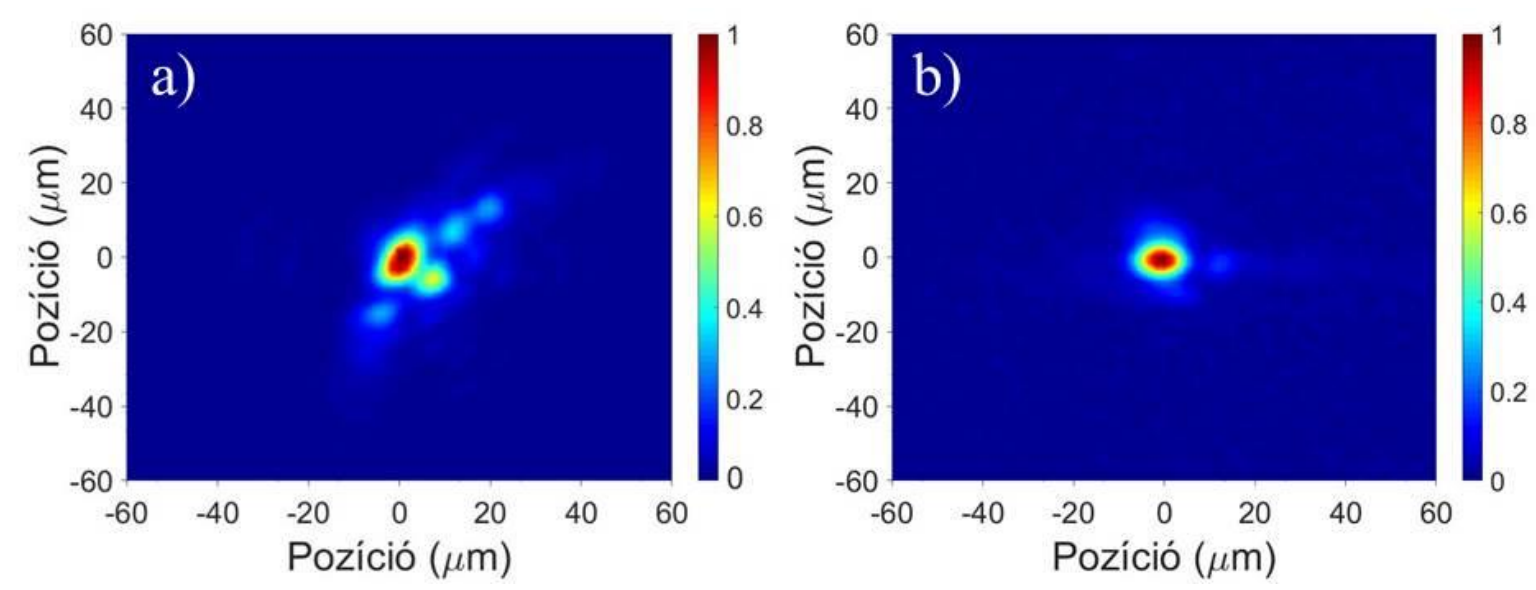

3-3. ábra

A céltárgyra eső nyaláb fókuszsíkbeli (a) és a fókuszáló lencse döntésével kompenzált (b) intenzitáseloszlása f/30 fókuszálás esetén.

A fókuszeloszlást figyelve a lencse két tengely körüli döntésével sikerült lényegesen jobb fókuszeloszlást produkálni. Egy jellemző felvétel a 3-3b. ábrán látható. A 3-3b. ábrának megfelelö 3 dimenziós ábrázolást a 3-4. ábra mutatja. A képen látható fókuszfolt nagysága (mindkét irányban) 1,5-ször nagyobb a diffrakció által limitált elméleti értékhez képest. (Megjegyzem, hogy a számítást téglalap alakú nyalábra végeztem, ami eltér a kör alakú vagy Gauss eloszlásoktól.) Az eloszlás alapján számolt fókuszált intenzitás értéke megközelíti a $10^{16} \mathrm{~W} / \mathrm{cm}^{2}$ értéket. (Az intenzitás kiszámításánál a félértékhez tartozó foltméretet és az abban foglalt energiát vettem alapul.)

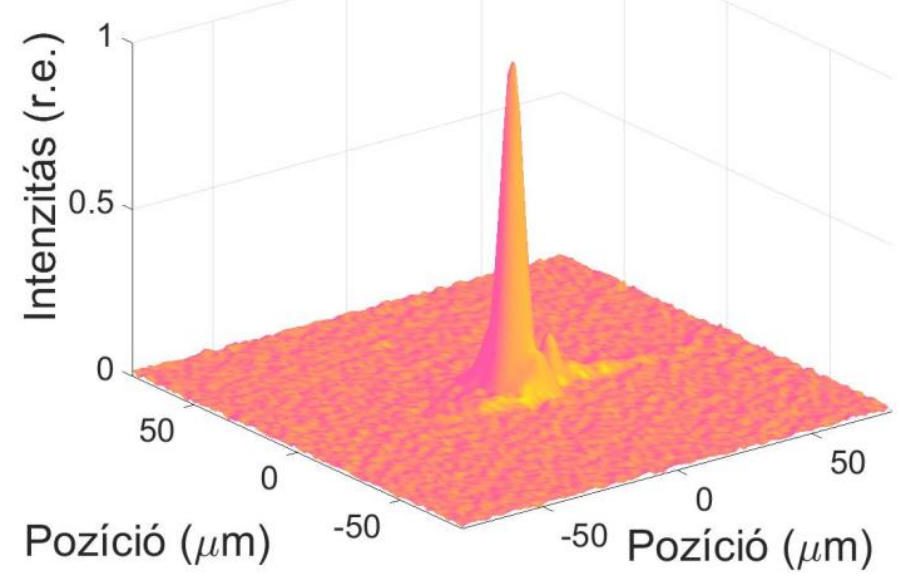

3-4. ábra

A plazma tükör reflexiójának vizsgálatához használt nyaláb fókuszsíkbeli eloszlása 3 dimenziós ábrázolásban [115]. 
A felvételek készítése során a fókuszeloszlás alakja stabilnak bizonyult. Az eloszlás mindig egy stabil kerek maggal rendelkezett és csak a mellette lévő mellékrendek nagysága változott. A plazma reflexiójának mérése során ezért nem tartottam szükségesnek a fókuszfolt alakjának lövésenkénti nyomon követését, de a kísérlet során rendszeresen ellenőriztem.

A kísérletek során a reflexió értékét p és s polarizációra is megvizsgáltam. A polarizáció változtatásához a lézerrendszerben egy ALPHALAS típusú 2,5 mm vastag $\lambda / 2$-es lemezt helyeztem el közvetlenül a frekvenciakétszerezés után (lásd 3-1. ábra). A kísérlethez használt lézernyaláb polarizációját a $\lambda / 2$-es lemez döntésésvel változtattam és a kísérleti asztalon egy Glan-Thompson-féle polarizátorral ellenőriztem a polarizáció szögét. Ez a megoldás könnyen lehetővé tette a polarizáció változtatását a kísérleti elrendezés módosítása nélkül.

Az alábbiakban ismertetem a plazma reflexiójára kapott eredményeimet. Mivel a mérések során egyidejüleg mértem a bemenő és a reflektált nyaláb energiáját, így a reflexió értékét mindig egy adott lövésre tudtam kiértékelni. A céltárgyon eső intenzitás változtatása során az alacsonyabb intenzitású pontok esetén a céltárgy mindig a fókuszsík elött volt. Az intenzitás függvényében kapott reflexió értékeket a 3-5a. ábra mutatja s- polarizációjú fény esetére. A mérés során a fókuszáló lencse eltolója által engedett legkisebb intenzitás $\sim 2 \cdot 10^{12} \mathrm{~W} / \mathrm{cm}^{2}$ volt. Látható, hogy már ebben az esetben is az impulzus felfutó éle által keltett plazma ( $\mathrm{R} \approx 5 \%$-os) reflexiója lényegesen nagyobb az anti-reflexiós réteggel bevont céltárgy reflexiójánál $(\mathrm{R}<1 \%)$. Az intenzitás növelésével a reflexió értéke monoton módon nő és $10^{14} \mathrm{~W} / \mathrm{cm}^{2}$ intenzitás felett meghaladja a korábban ugyanilyen paraméterü impulzusokkal elért 50\%-ot [36]. Az intenzitást tovább növelve a görbe meredeksége csökken, és több mint egy nagyságrendnyi tartományon $60 \%$ felett marad a reflexió. A kísérlet során alkalmazott maximális intenzitás esetén $\left(\sim 5 \cdot 10^{15} \mathrm{~W} / \mathrm{cm}^{2}\right) 70 \%$-os reflexiót elérő mérési pontok is előfordultak. A grafikonról az is jól látható, hogy az intenzitás növelésével a mérési pontok szórása is megnő. Ez elsősorban a nemlineáris rezonancia abszorpciónak és magasharmonikus-keltésnek köszönhető. 

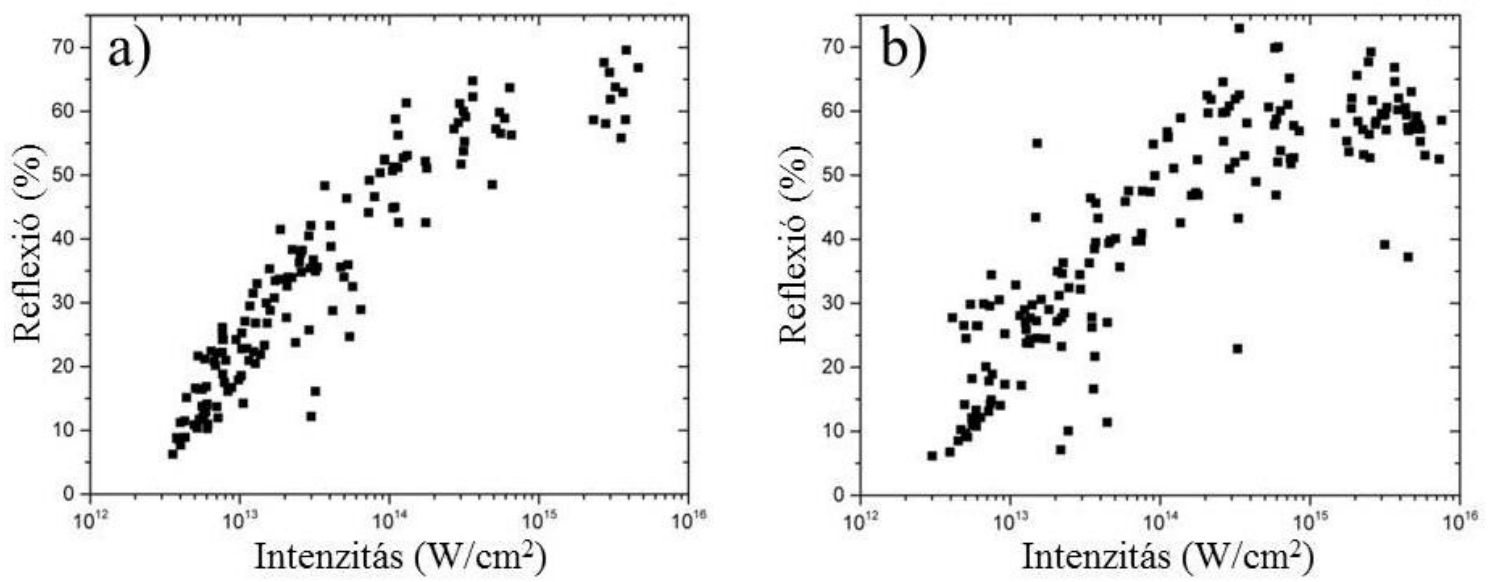

3-5. ábra

500 fs hosszúságú ultraibolya impulzusok által keltett plazma tükör intenzitásfüggö reflexiója s-és p-polarizáció esetén (a) ill. b) ábra) [115].

500 fs impulzushosszú és p-polarizációjú impulzusokat alkalmazva a nemlinearitások (rezonáns abszorpció és magasharmonikus-keltés) miatt fellépő szórás fokozott mértékben jelentkezik, ahogy azt a 3-5b. ábra mutatja. A megnövekedett szórástól eltekintve a görbe alakja megegyezik az s-polarizációjú esettel; a kezdeti meredeken emelkedő szakasz $\sim 10^{15}$ $\mathrm{W} / \mathrm{cm}^{2}$ intenzitás esetén az $\mathrm{R}=60 \%$ reflexió értékeknél telítődik. Egyes lövések esetén itt is elértük a 70\%-os reflexiót, amely a szakirodalomban publikált legmagasabb érték $248 \mathrm{~nm}$-es központi hullámhosszú impulzusokra.

\section{1.b. Plazma tükör reflexiójának vizsgálata 220 fs hosszúságú impulzusokkal}

A plazma tükör által elérhető maximális reflexió megközelítéséhez minél meredekebb plazma gradiens szükséges. A főimpulzus felfutó éle által keltett plazma gyorsan tágulni kezd, amelynek karakterisztikus ideje a néhány száz fs-os nagyságrendbe esik. Mivel ez a karakterisztikus idő összemérhető az általunk használt impulzus hosszával érdemes megvizsgálni az elérhető reflexió impulzushossztól való függését. A plazma tükörrel kapcsolatos szakirodalomban találhatók olyan infravörös lézerekkel végzett kísérletek, ahol a rövidebb impulzushossz nagyobb plazma reflexiót eredményezett. Ch. Ziener és munkatársai 500 fs-os impulzusokkal 80\%-os, míg 90 fs-ra kompresszált impulzusokkal 90\%-ot megközelítő reflexiót értek el 800 nm-es központi hullámhosszon [106]. A kísérleti elrendezésemet ezért úgy módosítottam, hogy a $\mathrm{KrF}$ ultraibolya lézerrendszer pozitívan fázismodulált impulzusait először kompresszáltam.

Az impulzusok összenyomása egy Treacy-típusú impulzus kompresszort építettem [117]. Ezen elrendezésben a rácspár által bevezetett negatív csoport késleltetés diszperzió 
kompenzálja a korábban elszenvedett pozitív anyagi diszperziót. A szokásos elrendezésben a rácspáron kétszer vezetik át a nyalábot (ellentétes irányban), ezáltal kompenzálva a frekvenciakomponensek terjedés irányára merőleges lecsúszását. Az általam épített elrendezésben (3-6.ábra) a kompresszáláshoz használt 1800 vonal/mm karcolat sürüségü optikai rács felületét kihasználva egy retroreflektorral visszatükröztem a nyalábot a rácsra, így a második rács szerepét is az első rács tölti be. A nyaláb a kompresszort csak egy irányban járja be, így a terjedési irányra merőleges spektrális elcsúszás nincs kompenzálva. A kísérlethez használt nagy nyalábméret és a viszonylag kis mértékủ csoportsebesség diszperzió miatt ez a hatás gyakorlatilag elhanyagolható, illetve a nyaláb szélének apertúrázásával praktikusan kiszürhető.

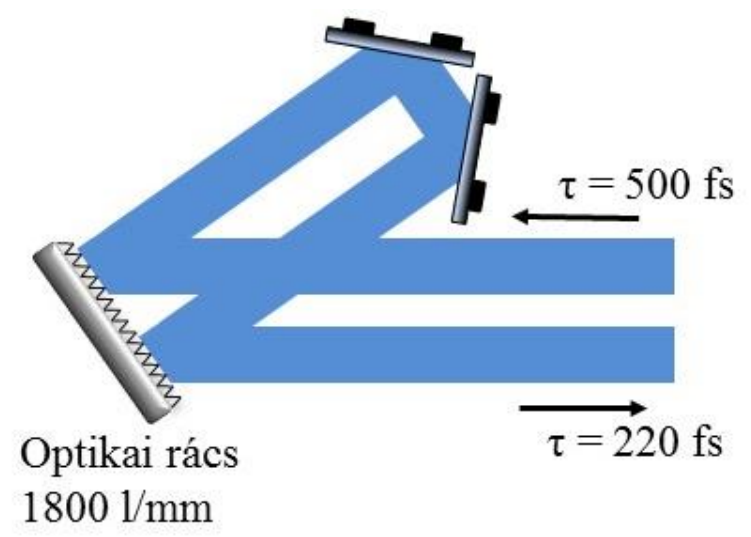

3-6. ábra

Az impulzus időbeli kompressziójához használt kísérleti elrendezés rajza.

Az optikai rácsot s-polarizációjú nyalábbal első rendben használva 50\%-os diffrakciós hatásfok érhető el (p-polarizáció esetén rosszabb a hatásfok). A rács kétszeri alkalmazása esetén ez 25\%-os transzmissziót jelent. További veszteség okozott, hogy a rács mérete miatt apertúráznom kellett a nyalábot, ami a nyalábkeresztmetszet 1,3 cm átmérőjü körre limitálta. Ezen tényezők a mérés során korlátozták az elérhető fókuszált intenzitás értékét. A polarizációt a reflexió mérésének során geometriai elforgatással változtattam.

A kompresszort elhagyó impulzusok időbeli karakterizálását egy másodrendű többlövéses autokorrelátorral végeztem el [68]. Az impulzushossz mérés elve, hogy egy Michelson-interferométer elrendezésben a két résznyaláb egyesítése után egy intenzitás szerint nemlineáris (esetünkben másodrendű) detektorral mérjük a két részimpulzus jelét az időbeli átfedés függvényében. A nemlinearitás miatt a bevezetett késleltetéstől függően változik a detektor által mért jel nagysága, és az így kapott autokorrelációs görbe jellemző lesz az impulzus alakjára. Nemlineáris detektorként NO gáz kétfotonos ionizációján alapuló 
ionizációs cellát alkalmaztam. A detektor által megszabott dinamikus tartomány nem nyújt lehetőséget az impulzustalp alakjának pontos méréséhez, azonban a félértékszélesség könnyedén meghatározható.

A kísérlet során az optikai rács és a retroreflektor távolságát változtatva mértem az impulzus félértékszélességét. A 3-7. ábrán látható az optimális kompresszióhoz tartozó legrövidebb impulzus (220 fs) esetén mért másodrendü autokorrelációs görbe. Ez lényegesen hosszabb, mint a korábban a szakirodalomban közölt 100 fs-os vagy az alatti impulzusidő. A rövid impulzusú festék-excimer hibrid lézerrendszerek esetén a kimenő impulzusok kompresszálhatósága a magimpulzus sávszélességén túl erösen függ az ultraibolya tartományban való erősítés telítésének mértékétől, és ehhez kötődően az erősítő $\mathrm{CaF}_{2}$ ablakaiban fellépő önfázismodulációtól. Az önfázismoduláció jelensége a spektrum kiszélesedéséhez, így elvileg rövidebb kompresszált impulzushosszhoz vezet. A kísérlet során a jó kontraszt érdekében az erősítési átmenetek - az erősítő geometriai tengelyéhez mért szögét viszonylag nagynak választottam $\left(1,4^{\circ}\right.$ ill. $\left.2.1^{\circ}\right)$, ugyanakkor ezzel elkerültem az erősítés mély telítődését. Ennek következtében az elérhető legrövidebb impulzushossz 200 fs-ra korlátozódott.

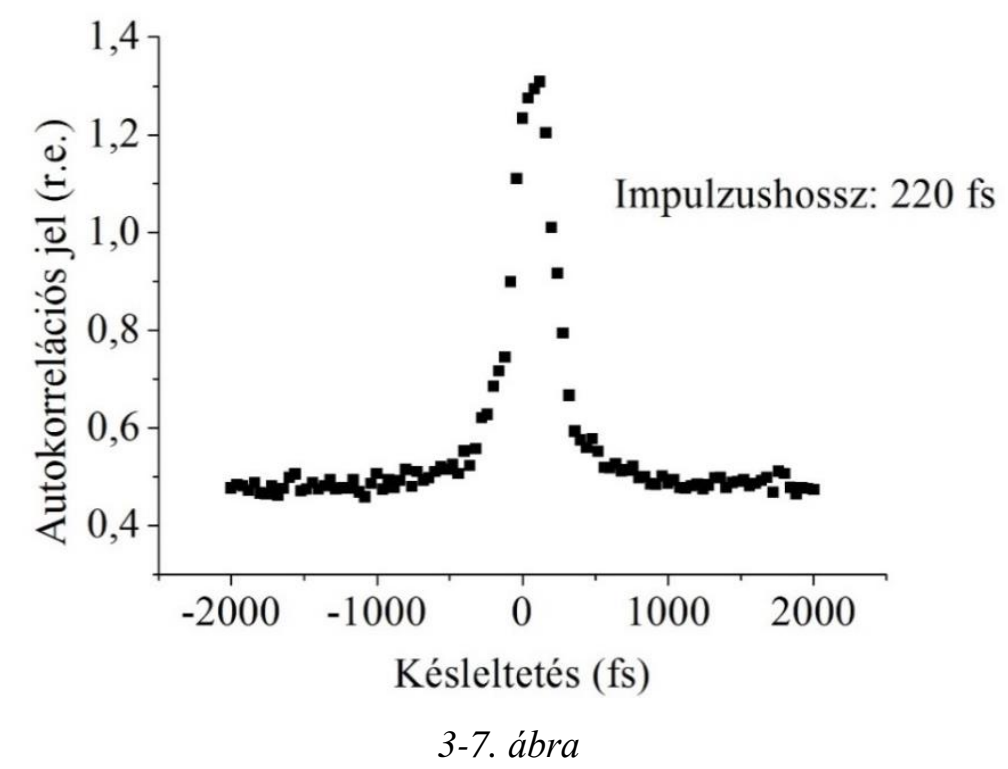

Az optimális impulzuskompresszióhoz tartozó másodrendü autokorrelációs görbe.

A 220 fs-os kompresszált impulzusokkal az intenzitás függvényében mért plazma reflexió értékek a 3-8a. és b. ábrán láthatóak. A kompresszálás során elszenvedett energiaveszteség miatt (és a 2-es faktorral történő impulzushossz rövidülés ellenére) a fókuszált intenzitás csúcsértéke nem haladta meg a $\sim 3 \cdot 10^{15} \mathrm{~W} / \mathrm{cm}^{2}$ értéket. A $10^{14}-10^{15} \mathrm{~W} / \mathrm{cm}^{2}$ tartományban a plazma tükör reflexiója 50 és 60\% között van, egyes lövések meghaladják a 
60\%-ot. Az impulzushossz méréséhez használt autokorrelátor a korlátozott dinamikai tartománya miatt nem képes az impulzus alakját a le- és felfutó részeken mérni. Ezért nem zárható ki, hogy a kompresszált impulzus rendelkezett olyan időbeli vállal vagy előimpulzussal, amely befolyásolta a plazma tükör reflexióját. További hatás lehet, hogy a kompresszióhoz szükséges több optikai elem negatívan befolyásolta a nyaláb fókuszálhatóságát. Az eredményeket az 500 fs-os esettel összevetve elmondható, hogy ugyanezen intenzitás tartományban a reflexió értéke nem lényegesen tér el a két esetben. Összegezve azt lehet állítani, hogy a plazma tükör technika hatékony müködését 220 fs-os impulzusokra is demonstráltam.
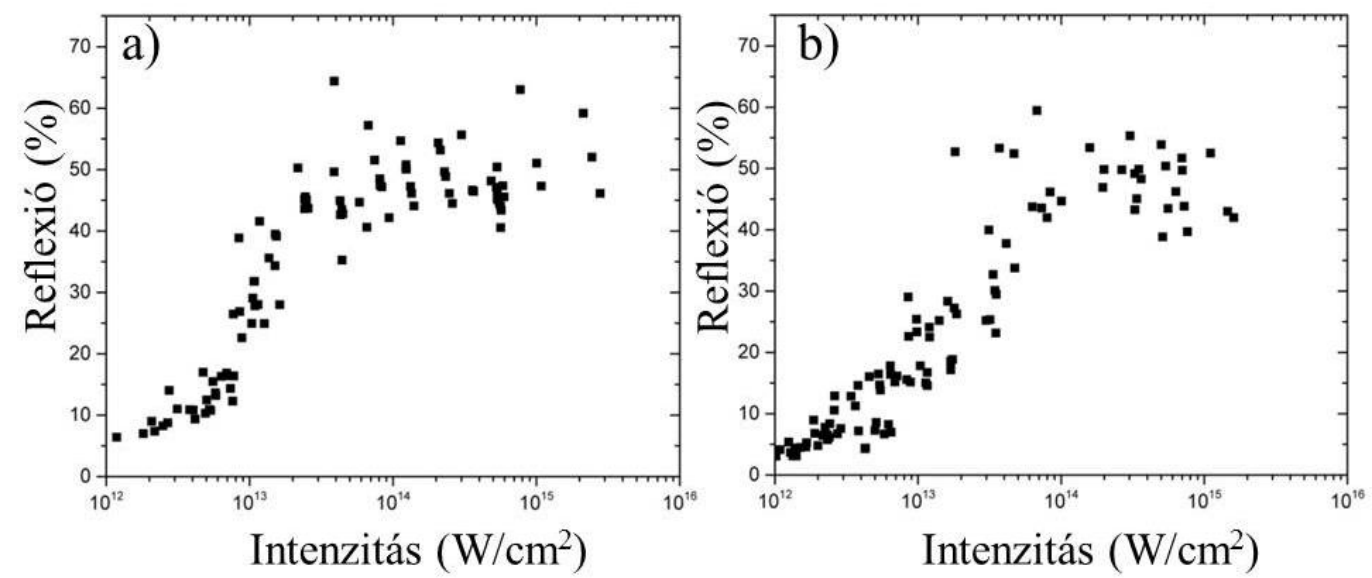

3-8. ábra

220 fs hosszúságú ultraibolya impulzusok által keltett plazma tükör intenzitásfüggő reflexiója s- és p-polarizáció esetén (a) ill. b) ábra) [115].

\section{1.c. Plazma tükör eljárással szürt impulzusok térbeli tulajdonságainak vizsgálata}

A plazma tükör alkalmazhatóságának szempontjából kiemelt jelentőséggel bír a plazma tükörről reflektált impulzus térbeli tulajdonsága, fókuszálhatósága. A plazma tükör által szürt impulzus további erősítése és nagyintenzitású fény-anyag kölcsönhatási kísérletekben való alkalmazása miatt fontos demonstrálni, hogy az impulzus időbeli és térbeli tulajdonságai nem változnak a szürés során. Ennek tanulmányozására a 3-9. ábrán látható elrendezést építettem fel. A céltárgyról reflektált nyalábot először egy $\mathrm{f}_{3}=45 \mathrm{~cm}$-es lencsével kis mértékben konvergenssé tettem, majd egy másik ugyancsak $\mathrm{f}_{4}=45 \mathrm{~cm}$-es gyüjtőlencsével fókuszáltam. A fókuszsíkot egy $\mathrm{f}_{5}=5 \mathrm{~cm}$-es gyüjtőlencsével $\mathrm{N}=13$-szoros nagyítással képeztem a kamerára. Az első lencse után egy $\mathrm{R}>99,5 \%$ reflexiójú kvarc hordozójú dielektrikum tükörrel gyengítettem a nyalábot, majd szürkeszürök használatával $(\mathrm{OD}=3$ és $\mathrm{OD}=1)$ a $\mathrm{CCD}$ kamera 
telítési szintje alá csökkentettem a fény intenzitását. A kamera elé egy $20 \mathrm{~cm}$ hosszú csövet és egy $3 \mathrm{~mm}$ átmérőjü íriszt helyeztem a háttérfény kiszürésének érdekében.

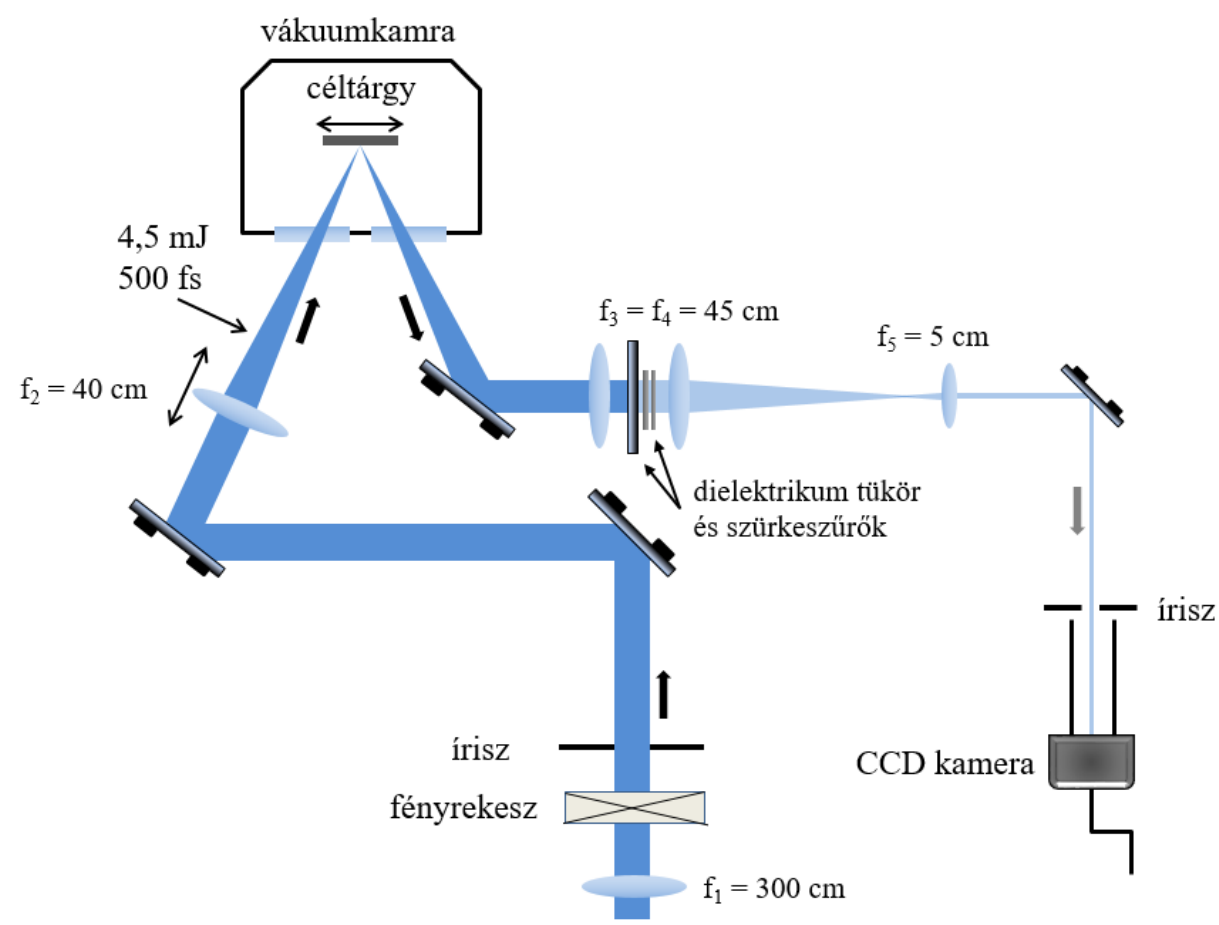

\section{3-9. ábra}

A plazma tükörröl reflektált nyaláb térbeli eloszlásának vizsgálatára használt kísérleti elrendezés sematikus rajza.

A bemenő impulzus Fourier-síkbeli eloszlását a korábban látott 3-4. ábra mutatja. A fókuszfolt mérete 1,5-szerese az elméleti, diffrakció-limitált esetnek. A plazma tükörről reflektált impulzus Fourier-síkbeli eloszlását a 3-10. ábra mutatja. Látható, hogy a bemenő esethez hasonlóan az eloszlás egy szabályos középső maximummal rendelkezik. A mellékmaximumok nagysága nem haladja meg a 10\%-ot és a fókuszfolt mérete az elméleti diffrakció-limitált eset 1,75-szerese. Ezek alapján kijelenthető, hogy a reflektált impulzus a bemenőhöz hasonlóan kiváló térbeli tulajdonságokkal bír. Megjegyzendő, hogy esetleges további erősítés során a nyaláb közeli zónabeli esetleges inhomogenitása az erősítés telítődése miatt javítható. 


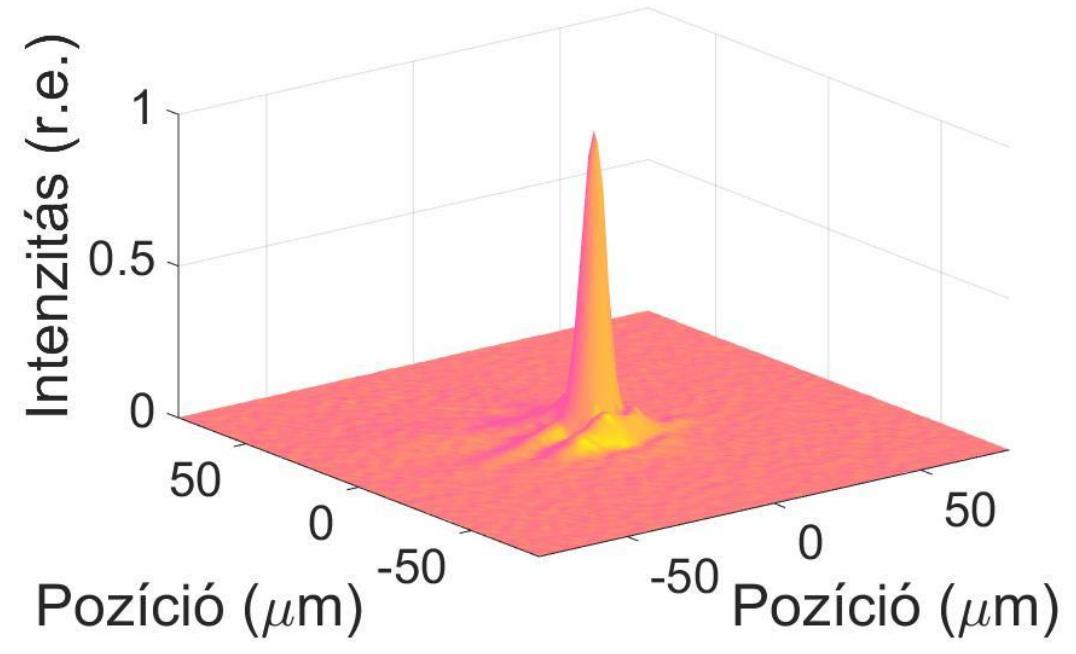

3-10. ábra

A plazma tükör által reflektált nyaláb fókuszsíkbeli intenzitáseloszlása [115].

\section{1.d. Diszkusszió}

A fent ismertetett eredményeim alapján kijelenthető, hogy sikerült a korábban a szakirodalomban publikált értéknél magasabb reflexiójú plazma tükör müködést demonstrálnom rövid ultraibolya lézerimpulzusokra. A maximális reflexió megközelíti a $70 \%$-ot és a nyaláb kiváló térbeli tulajdonságai is fenntarthatók a folyamat során. Figyelembe véve, hogy a nagyjelü és kisjelü reflexió aránya meghaladja a két nagyságrendet az elrendezés egy hatékony kontrasztjavító eljárásnak tekinthető. A maximális reflexió értéke továbbá az impulzus paramétereinek kontrollja lehetővé teszi az elrendezés rövid impulzusú $\mathrm{KrF}$ lézerrendszerbe történő integrálását, ahol a szürés egy két erősítési fokozatból álló lánc közepén vagy végén kaphat helyet. A technikának az erősítőlánc végén történő alkalmazása elsősorban praktikus okok miatt nehézkes. Ugyanis ekkor a plazma reflexió letörésének elkerülése végett, vagy a fókuszsíkon kívül kellene plazmát kelteni, vagy a megnövekedett energia miatt kisebb nyílásszögü lefókuszálást alkalmazni. Előbbi a kiterjedt nyalábméret és a céltárgy felszínén keltett plazma nem ismert felületi egyenetlensége miatt fázisfront torzulást vezethet be. Utóbbi pedig a laborunkban található végerősítésre jellemző $>60 \mathrm{~mJ}$ és $\sim 3,8 \mathrm{~cm}$ es nyalábméret mellett $10 \mathrm{~m}$ feletti optikai úthossz növekedést illetve speciális vákuumkamra elrendezést igényel.

Fenti eredményeim alapján a plazma tükörnek egy nemlineáris Fourier-szürési elrendezésben amplitúdómodulációra való alkalmazása az alacsony energia hatásfokon túl további problémákat vet fel. A reflexió értékének az intenzitástól való függése nem elég 
meredek ahhoz, hogy egy gyürü alakú nyaláb Fourier-síkjában lévő mellékmaximumokat megfelelő mértékben elnyomja. Ahogy a 3-5a. ábrán látható a görbe legmeredekebb szakaszán a gyürü alakú nyaláb Fourier-síkbeli eloszlásának maximumához és az első mellék maximumához tartozó reflexiók aránya csupán $\sim 8$. (A 3-5a ábrán a $3 \cdot 10^{14} \mathrm{~W} / \mathrm{cm}^{2}$ értékhez tartozó $\sim 40 \%$-os és a $3 \cdot 10^{13} \mathrm{~W} / \mathrm{cm}^{2}$ értékhez tartozó $\sim 5 \%$-os reflexió értékek.) A plazma tükröt amplitúdó-modulációra használó nemlineáris Fourier-szürési elrendezés ugyan kontrasztjavításban hatékonyabb, de energiaveszteséget tekintve nagyságrenddel kedvezőtlenebb lenne a fázis-moduláción alapuló eljáráshoz képest. 


\subsection{Optikai leképezés kontrasztjának modellezése}

A 2.3 fejezetben bemutattam egy új, ígéretes kontrasztjavító eljárást, a nemlineáris Fourier-szürést, ami a fókuszsíkban bevezetett nemlineáris fázis-moduláción alapul. Az ott bemutatott szürési elrendezés hátránya, hogy a nemlineáris folyamat által kínált kontrasztjavulás praktikusan nem realizálható, egy a nemlineáris kölcsönhatástól függetlennek bizonyuló tényező miatt. A technikával elérhető kontrasztjavulást a nagyjelű és a kisjelü transzmisszió hányadosa definiálja. A kísérletek szerint a kisjelü transzmissziót elsődlegesen az szabja meg, hogy a bemenő oldali apertúrát a konfokális teleszkóp első lencséje mekkora térbeli kontraszttal tudja leképezni a kimenő oldali apertúra síkjára. A térbeli kontraszt ebben az esetben a képsíkban a gyürü alakú nyalábnak és a gyürü közepén mérhető (ideális esetben nulla értékü) sötét résznek az intenzitásaránya. A nemlineáris Fourier-szürővel elérhető kontrasztjavulás kiterjesztése így egy klasszikus optikai kérdéskörbe tartozó probléma megoldását igényli. Mivel egy leképezés térbeli kontrasztját elsősorban a diffrakció szabja meg, ezért ennek a kérdéskörnek a vizsgálata hullámoptikai eszközökkel végezhető. Ezen fejezetben bemutatott kutatásaim az optikai rendszerek által alkotott kép térbeli kontrasztjának modellezését célozzák. A modellezés segítségével megvizsgálom az optika más területén használt technikákat a leképezés térbeli kontrasztjának növelésére és javaslatot teszek a nemlineáris Fourier-szürési technika kísérleti elrendezésének javítására [118].

\section{2.a. Optikai leképezés térfrekvenciás analízisen alapuló szimulációja}

Az optikai leképezések elméleti tanulmányozása és kísérleti alkalmazása a fizika egyik részletesen kutatott kérdésköre. A témában nagyon gazdag irodalom és nagy felhalmozott tudás áll rendelkezésre. A leképezés térbeli kontrasztja - azaz a fekete és fehér részek intenzitásaránya - is fontos szerephez jut például a mikroszkópiában és a fényképészet több területén. Ennek javítására több módszert is alkalmaznak (a leképezés nyílásszögének növelése és ún. apodizációs szürők alkalmazása). A nemlineáris Fourier-szürés esetében azonban a leképezés hagyományos alkalmazásán túlmutató, akár 5-10 nagyságrendet meghaladó tartományon kell értelmezni illetve vizsgálni a kép kontrasztját. Ezért szükséges egy olyan szimuláció megalkotása, amely ebben a nagyságrendben is modellezni tudja egy leképező rendszer térbeli kontrasztját. Ezzel tesztelni tudjuk az irodalomban fellelhető képkontraszt-javító eljárások hatását, valamint a leképezési hibák jelentőségét. 
Mint fent említettem a leképezés leírására hullámoptikai módszert érdemes használni, mivel a kísérletek tanulságai szerint elsősorban a diffrakció jelensége okozza a térbeli kontraszt limitációját. Érdemes megjegyezni, hogy ha ezen feltételezés helyes, akkor a hullámoptikai (vagy skalár hullám) leírás elégséges és jóval egyszerübb kezelését jelenti a problémának, mintha a mindenre kiterjedő fizikai optikai leírást választanánk. Az optikai leképezés skalár hullám leírása az optikai rendszer impulzusválasz-függvényén alapszik. A képsíkbeli eloszlást az impulzusválasz-függvény és tárgysíkbeli eloszlás konvolúciója adja. Egy diffrakció-limitált leképező rendszer esetén - azaz ha a leképezési hibák elhanyagolhatók és csak a diffrakció hatását vizsgáljuk - az impulzusválasz-függvényt a rendszer kilépési pupillájának Fraunhofer-féle elhajlási képe adja.

A fenti megközelítéssel matematikailag egyenértékü az optikai leképező rendszerek térfrekvenciás analízissel történő leírása. Ezen leírásban a tárgy- és képsíkbeli amplitúdóeloszlás (térváltozók szerint) kétdimenziós (2D-s) Fourier-transzformáltjai $\left(G_{\text {tárgy }}\left(f_{x}, f_{y}\right)\right.$ és $\left.G_{k e ́ p}\left(f_{x}, f_{y}\right)\right)$ között teremtünk kapcsolatot.

$$
G_{k \text { ép }}\left(f_{x}, f_{y}\right)=H\left(f_{x}, f_{y}\right) \cdot G_{\text {tárgy }}\left(f_{x}, f_{y}\right)
$$

Az összefüggésben szereplő $H$ a leképező rendszerre jellemző transzfer függvény. Mivel ez a megközelítés a 2D-s Fourier-transzformáltak szorzatára épül ezért egy számítógépes numerikus szimuláció esetén lényegesen előnyösebb. Ezért a probléma megközelítését a leképező rendszerek térfrekvenciás analízisére alapoztam.

A pontos számításokhoz lényeges megkülönböztetni két esetet; a koherens és az inkoherens megvilágítást. Koherens esetben az (3-1) egyenletben szereplő $G$ függvények a skalár hullám eloszlás amplitúdójának a Fourier-transzformáltjait, a $H$ függvény pedig az impulzusválasz-függvény Fourier-transzformáltját jelenti, az ún. amplitúdó transzfer függvényt. Ezzel szemben inkoherens esetben $G$ helyébe az intenzitáseloszlás Fouriertranszformáltja kerül $H$ pedig az ún. optikai transzfer függvény, amit az amplitúdó transzfer függvény normált autokorrelációs függvénye ad meg.

A nemlineáris Fourier-szürés esetében vizsgált kérdés az, hogy az ASE által kivilágított gyürű alakú apertúrát mekkora térbeli kontraszttal lehet leképezni. Praktikusan ez szabja meg, hogy az ASE mekkora részét tudjuk kiszürni. Az ASE térben csak részben koherens, így szigorúan véve sem az amplitúdó transzfer függvénnyel, sem az optikai transzfer függvénnyel nem lehet leírni a leképezését. Ennek megfelelően egy ASE-val kivilágított tárgy leképezése 
esetén a térbeli kontraszt értéke a koherens és az inkoherens számítási módszerrel kapott értékek közé kell, hogy essen. Érdemes megjegyezni azonban, hogy az alkalmazások szempontjából praktikusan az ASE csak azon része okoz problémát, amely a főimpulzussal megegyező térszögben terjed, azaz térben koherens. Egy klasszikus térszürési elrendezéssel az ASE más irányban terjedő része egyébként is kiszürhető. Ennek megfelelően az alkalmazások vonatkozásában a koherens megvilágítással történő számolás a mérvadó.

\section{2.b. Optikai leképező rendszerek térbeli kontrasztjának modellezésére kapott eredmények}

Az amplitúdó transzfer függvény a leképezés impulzusválasz-függvényének a Fouriertranszformáltja. Mivel egy diffrakció-limitált rendszer esetén az impulzusválasz-függvény megegyezik a kilépési pupilla - esetünkben a lencse apertúra - Fraunhofer-féle elhajlási képével, ezért az amplitúdó transzfer függvény alakja megegyezik magával a lencse apertúrájával. A térfrekvenciás síkon értelmezve ez azt jelenti, hogy a lencse mint leképező rendszer egy bizonyos térfrekvencia értékig minden frekvencia komponenst az eredeti amplitúdójával transzferál, de ezen határértéken túl nullára csökken az átvitel. Ezt a levágási frekvenciát a $\lambda$ hullámhossz és a lencse f-száma $(F)$ határozza meg az alábbi összefüggés szerint

$$
f_{0}=1 / 2 \lambda F
$$

Térben inkoherens megvilágítás esetén a lencse átvitelét az optikai transzfer függvény írja le, ami az amplitúdó transzfer függvény autokorrelációs függvénye. Amint az belátható [119] a levágási frekvencia ebben az esetben $2 \cdot f_{0}$-ra módosul, az átvitel amplitúdója viszont csak a nulla frekvenciánál egységnyi értékü és a levágási frekvencia felé haladva monoton módon csökken nulláig.

A leképezés kontrasztjának numerikus szimulációját MATLAB környezetben végeztem. Első lépésként egy 2 dimenziós egységnyi amplitúdójú gyürü alakú eloszlást generáltam ugrásszerü élekkel a vizsgálandó kísérleti esetnek megfelelően. Az eloszlást egy N x N méretü tömb közepén helyeztem el N/8-as méretü külső sugárral. Az N értékét az általam használt asztali számítógép kapacitásához igazítva 4096-nak választottam. A gyürü alakú eloszláson kívül a tömböt 0 értékű pontokkal töltöttem fel a Fourier-képbeli eloszlás jobb felbontása érdekében. A tárgysíkbeli eloszlás Fourier-transzformáltjának kiszámításához a szoftverbe beépített gyors Fourier-transzformációs függvényt használtam. Az amplitúdó transzfer függvényt szintén egy $\mathrm{NxN}$ méretű tömbben definiáltam a térfrekvenciás síkon 
értelmezve. Az optikai transzfer függvény kiszámításához a szoftverbe beépített konvolúciós függvényt használtam. A különböző levágási frekvenciákhoz tartozó transzfer függvényeket csak egyszer generáltam, a képsíkbeli eloszlások számításaihoz az előre generált tömböket hívtam meg a programban, ezzel is gyorsítva a számítást. A képsíkbeli eloszlás Fouriertranszformáltját a transzfer függvény és a tárgysíkbeli eloszlás Fourier-transzformáltjának szorzata adja, ebből inverz transzformációval kapjuk a képsík eloszlását. Inkoherens esetben ez rögtön az intenzitáseloszlást adta meg, míg koherens esetben ez még csak az amplitúdóeloszlást jelenti. A képsíkbeli intenzitáseloszlás kiszámítását koherens és inkoherens esetre is több levágási frekvencia mellett (azaz eltérő f-számú leképező rendszereket vizsgálva) is elvégeztem. Az elvárás szerint, minél kisebb egy leképezés f-száma annál több térfrekvencia komponens kerül feldolgozásra és egyre inkább megközelíti a kép az eredeti eloszlást, így annak térbeli kontrasztját is. Az 3-11. ábrán látható a számolás eredménye két különböző levágási frekvenciára $\left(f_{0}=500 \mathrm{~cm}^{-1}\right.$ és $\left.f_{0}=1000 \mathrm{~cm}^{-1}\right)$ koherens és inkoherens esetre. Az $500 \mathrm{~cm}^{-1}$ levágási térfrekvencia a nemlineáris Fourierszürés kísérleti megvalósítását és az ott alkalmazott optikai elrendezését hivatott modellezni.

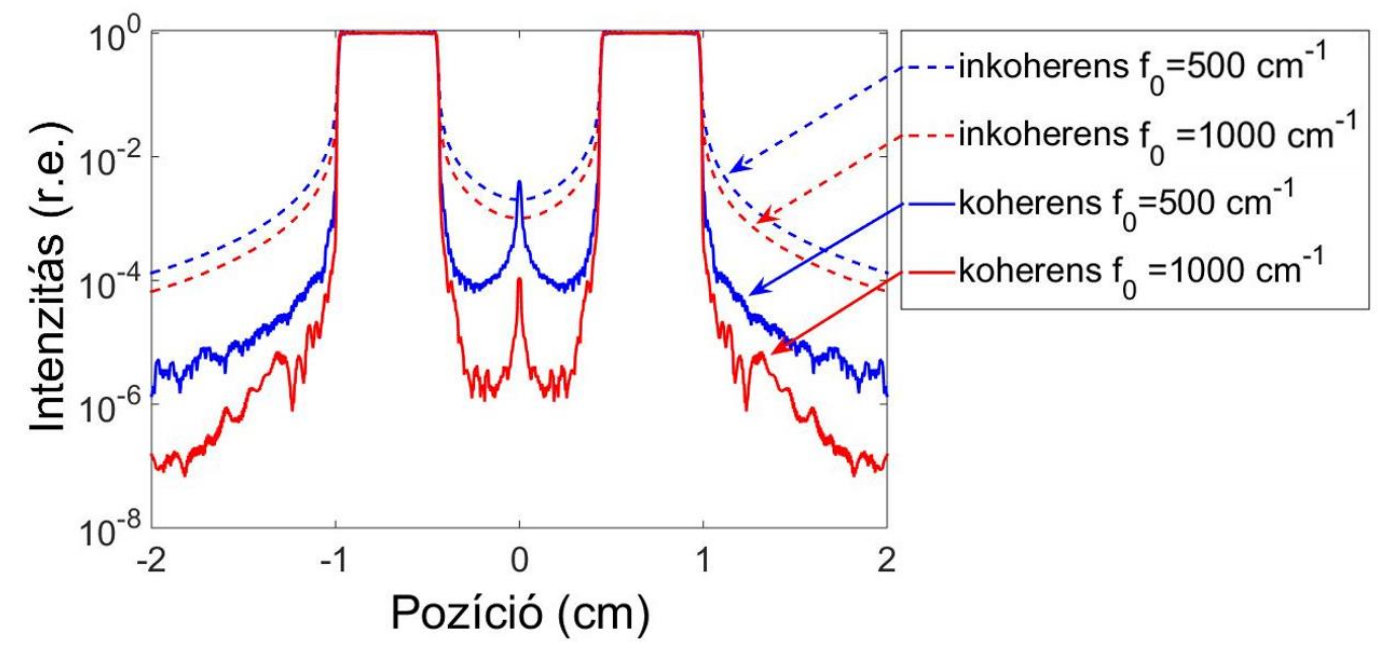

3-11. ábra

Egy gyürü alakú tárgy numerikus szimulációval kapott képsikbeli intenzitáseloszlása koherens (folytonos vonal) és inkoherens (szaggatott vonal) megvilágitás esetén egy $f_{0}=$ $500 \mathrm{~cm}^{-1}$ (kék görbe) és egy $f_{0}=1000 \mathrm{~cm}^{-1}$ (piros görbe) levágási frekvenciával bíró leképezö rendszer esetén [118].

Az 3-11. ábráról leolvasható, hogy a kísérleti esetnek megfelelő levágási frekvenciánál a gyürü közepén a térbeli kontraszt koherens esetben $10^{4}$, inkoherens esetben $10^{3}$ érték körül van. Ez az adat jól egyezik a részben koherens ASE-ra kísérletileg tapasztalt $10^{3}$ értékkel. Az 
ábráról az is leolvasható, hogy - az elvárásnak megfelelően - a levágási frekvencia növelésével a kép kontrasztja is javul.

A fenti modellezés elsődleges eredménye az, hogy a diffrakció hatása miatt az éles határokkal rendelkező tárgyakat az optikai tartományban - még leképezési hibáktól mentes rendszer esetén is - csak gyenge térbeli kontraszttal lehet leképezni. Ennek szemléletes oka az, hogy a leképező rendszer nem képes a tárgy nagyfrekvenciás térkomponenseit feldolgozni. Kézenfekvő elvi megoldás lenne a leképező rendszer levágási frekvenciájának növelése, azaz f-számának a csökkentése. A nemlineáris Fourier-szürési elrendezésben azonban a fókuszáláshoz használt lencse f-számát más a fókuszsíkban lezajló nemlineáris kölcsönhatáshoz köthető tényezők is befolyásolják. Az általam végzett nemlineáris Fourierszürési kísérletek során 30-as f-szám alatt a szürés irregulárisabb kimeneti eloszlást eredményezett és instabilabban müködött. 20-as f-szám alatt pedig csak a keltett plazmában való szórást tapasztaltam a kimenten. A leképezéssel elérhető térbeli kontrasztnak nem csak az alkalmazott f-szám, de a leképezéshez használt hullámhossz is elvi határt szab. Az optikai tartományba eső hullámhosszak $\sim 10^{4}$-szer nagyobbak, mint a leképezni kívánt atomi léptékü változások.

Az optikai leképezéssel elérhető térbeli kontraszt modellezését érdemes kiegészíteni a leképezési hibák hatásának vizsgálatával. A leképező rendszerek térfrekvenciás analízise lehetőséget nyújt az ismert fázisfront torzítással bíró aberrációk modellezésére is. Ehhez csupán az amplitúdó transzfer függvényt kell megfelelően módosítani. Nevezetesen a pupilla függvényt Euler-féle komplex alakban írjuk fel, ahol az amplitúdó megegyezik az eddigi pupillafüggvénnyel, a fázistag viszont egy térben függő fázishibát ad meg az ideálisnak tekintett (a diffrakció által megszabott) fázisfronthoz képest. A 3-12. ábrán a szférikus aberráció hatását vizsgáltam a kép térbeli kontrasztjára inkoherens és $f_{0}=500 \mathrm{~cm}^{-1}$ esetre. Az ábrán 3 görbe van feltüntetve; a diffrakció limitált eset és két különböző mértékủ szférikus aberrációval terhelt eloszlás, ahol a pupilla függvény határán a fázishiba $\lambda / 4$ ill. $\lambda / 2$ értéket vesz fel. (A szférikus aberráció a pupilla függvény centrumától mért sugár negyedik hatványa szerint növekvő fázishibával írható le). Látható, hogy a fázishiba maximális értékének növelésével jelentősen csökken a kép térbeli kontrasztja. Így a leképezés f-számának csökkentése ezen hatás miatt sem kívánatos. 


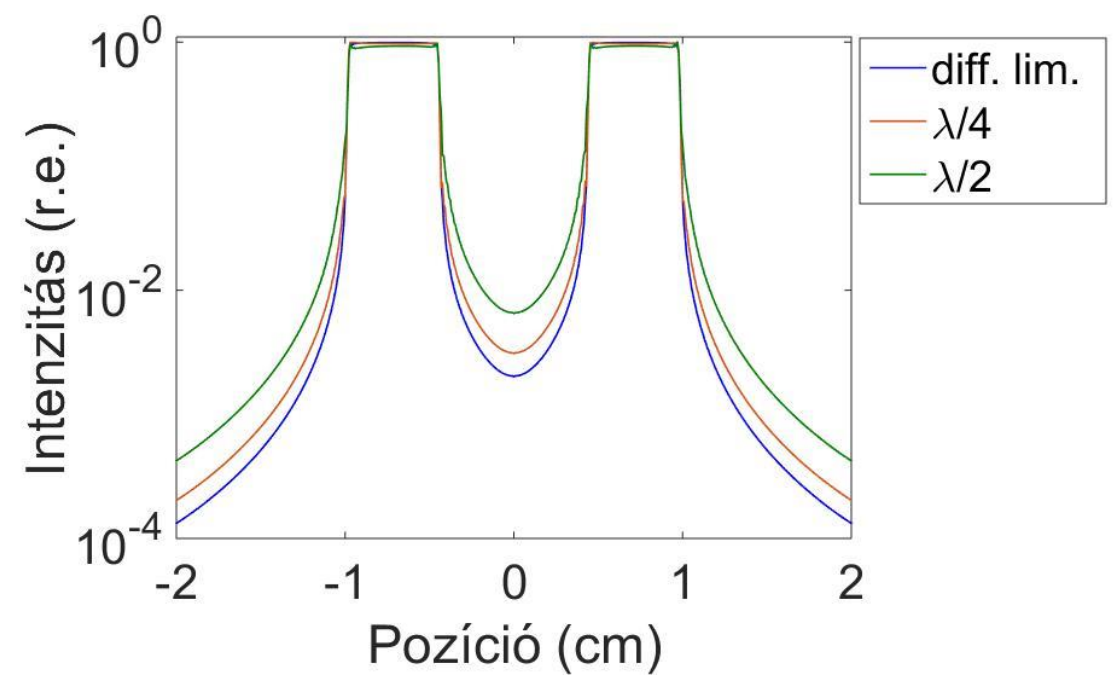

3-12. ábra

Egy gyürü alakú tárgy szimulált képsíkbeli intenzitáseloszlása diffrakció limitált esetben (kék görbe) és két különbözö mértékü szférikus aberrációval terhelt leképezés esetén, ahol

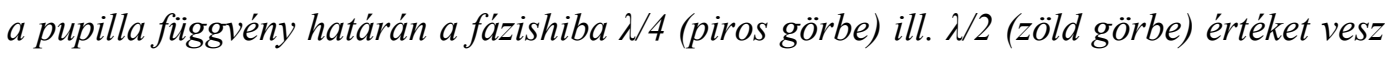
fel. A szimuláció paraméterei: inkoherens megvilágitás, $f_{0}=500 \mathrm{~cm}^{-1}$ levágási frekvencia.

\section{2.c. Leképezés térbeli kontrasztjavításának lehetőségei}

Az optikai leképező rendszerek véges levágási frekvenciája csak az egyik tényező, ami rossz irányba befolyásolja a kép térbeli kontrasztját. A magas háttérhez az is hozzájárul, hogy a térfrekvenciás térben történő szelekció ugrásszerüen történik. Ez a probléma hasonló a digitális jelfeldolgozásban alkalmazott mintavételi ablakfüggvények alkalmazásával. Mint ismert, a Fourier-síkban végrehajtott ugrásszerü moduláció az inverz térben jelentős amplitúdójú mellékcsúcsokat eredményez a logaritmikus skálán. A digitális jelfeldolgozásban a különböző szempontok szerint kifejlesztett ablakfüggvényeknek tekintélyes irodalma van. Az optikában ennek a hatásnak a csökkentésére (a térbeli kontraszt növelésére) szolgál az apodizáció bevezetése. Ennek lényege, hogy a pupillafüggvény meredekségét a széleken csökkentjük valamilyen simító függvény alkalmazásával (a levágási frekvencia változtatása nélkül). A képalkotási technikában erre a célra ún. apodizációs szürőket használnak. Érdemes megjegyezni, hogy az apodizáció alkalmazása a térbeli kontraszt javulása mellett mindig a kép élességének romlásával is jár. Esetünkben ez nem jelentős probléma a szürési elrendezésben csupán a kimenő oldali apertúra méretét befolyásolja kis mértékben.

Az apodizáció által kínált kontrasztjavulás tanulmányozására az általam készített szimulációban különböző ablakfüggvények felhasználásával generáltam pupillafüggvényeket. 
A 3-13. ábrán látható a háromszög és Gauss alakú transzmissziójú pupillafüggvénnyel végzett számítások összehasonlítása a korábbi inkoherens egységnyi amplitúdójú (négyszög alakú) pupillafüggvénnyel számolt eredménnyel. Látható, hogy bizonyos ablakfüggvények alkalmazásával a leképezés térbeli kontraszját a korábbi $10^{3}$ értékről $10^{6}$ értékre javíthatjuk. A háromszög és Gauss ablak két kézenfekvő választás a térfrekvenciás térben történő levágás csillapítására. Érdemesnek tartom megemlíteni, hogy modellezésem során több ablakfüggvény hatását is teszteltem (7 tagból álló Blackman-Harris, Nuttal, stb.), amelyekkel valamivel több mint egy nagyságrenddel kedvezőbb eredményt lehet elérni. A függvények bonyolultsága okán azonban egy ilyen apodizációs szürő kivitelezése és alkalmazása nehézkes lenne. Gauss eloszlású apodizációs szürők kaphatók kereskedelmi forgalomban, azonban a speciális hullámhossz és alkalmazás egyedi megvalósítást kíván, így tekintélyes áron szerezhetők csak be.

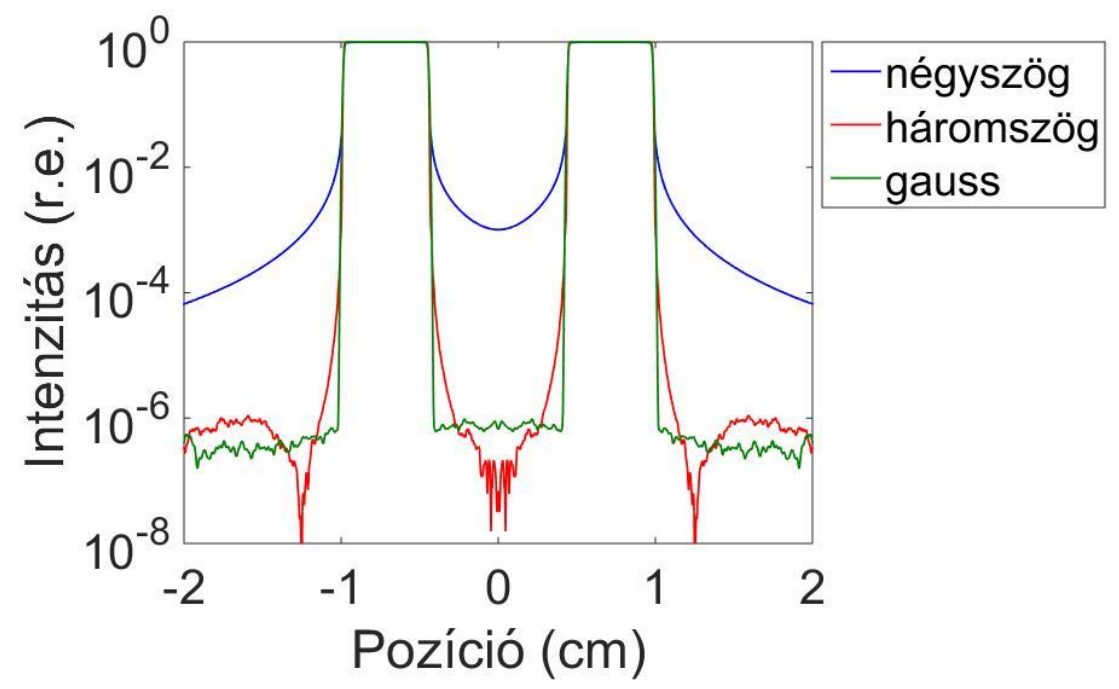

3-13. ábra

Egy gyürü alakú nyaláb szimulált képsíkbeli eloszlása egységnyi amplitúdójú (kék görbe), háromszög (piros görbe) és Gauss (zöld görbe) áteresztési függvénnyel rendelkezö pupillafüggvény esetén. A szimuláció paraméterei: inkoherens megvilágítás és $f_{0}=$ $500 \mathrm{~cm}^{-1}$ levágási frekvencia.

A fentiekben azt vizsgáltuk meg, hogy a leképező rendszer tulajdonságainak javításával (az f-szám ill. a pupillafüggvény módosításával) hogyan érhető el kedvezőbb térbeli kontraszt. Egy másik előnyösebbnek tủnő megközelítés, hogy nem a leképező rendszert módosítjuk, hanem a tárgy magas térfrekvenciás komponenseit formáljuk a leképező rendszer térbeli feloldásához igazítva. A gyakorlatban ez azt jelenti, hogy a gyürü alakú apertúra éleit valamilyen simító függvénnyel lekerekítjük, így a magas frekvenciájú térkomponensek 
szerepe csökken a leképezés során. Ilyen apertúraként az apodizációs szürökhöz hasonlatosan térben változó transzmissziójú szürők szolgálhatnak. Egy ilyen apertúra megvalósítása azonban technikailag bonyolult. Ennél előnyösebbnek tünik, ha a korlátozott térkomponensü tárgyat úgy állítjuk elő, hogy az éles tárgyat egy kis térbeli feloldású (kis nyílásszögü) rendszerrel képezzük le. Így egy lekerekített élekkel bíró (homályos) gyűrű alakú eloszlást kapunk, aminek a térbeli kontrasztja természetesen kicsi lesz, de a lekerekített élek meghagyásával egy második apertúrával kitakarhatjuk a sötétnek szánt részeket. Ez a homályos kép a második apertúrával kiegészülve jelentheti az új tárgyat, illetve a bemeneti nyalábot a nemlineáris Fourier-szürésnek.

Ennek a korlátozott térkomponensü tárgynak az előállítását szemlélteti a 3-14. ábra. Az ábrán az éles, gyürű alakú tárgy és ennek nagy f-számú elő-leképezéssel nyert térbeli intenzitáseloszlása látható. A leképező rendszer a tárgy Fourier-síkbeli eloszlásának első 10 maximumát engedi át. A képsíkban a második apertúra a $10^{-3}$ intenzitás szint alatti részeket kitakarja. Látható, hogy az elő-leképezéssel nyert tárgy kevésbé éles lefutású. Azt várjuk, hogy ezt, mint tárgyat lényegesen nagyobb kontraszttal lehet leképezni.

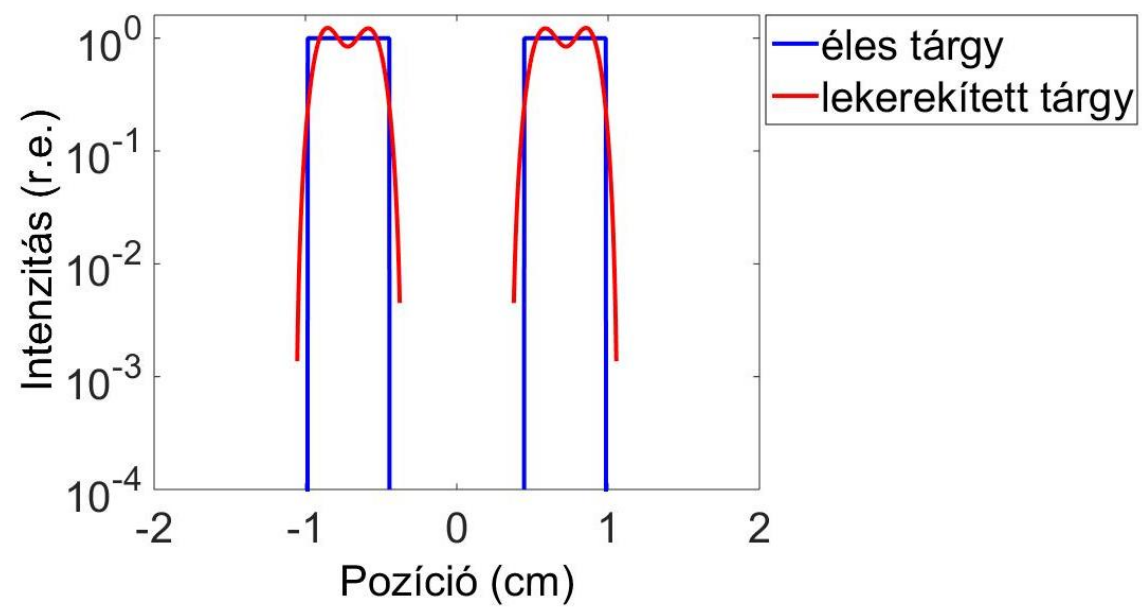

3-14. ábra

Az éles gyürü alakú tárgy (kék görbe) illetve kis nyílásszögü elö-leképezéssel nyert lekerekitett tárgy (piros görbe) szimulált tárgysíkbeli intenzitáseloszlása. (A szimulált elöleképezés során koherens megvilágitást és az első tíz Fourier-sikbeli maximum feldolgozását tételeztem fel.)[118]

A 3-15. ábrán látható ezen két (éles és lekerekített) tárgy leképezésének szimulációja. Ez a második leképezés a kísérletileg is használt leképezés paramétereivel egyezik meg $\left(f_{0}=\right.$ $500 \mathrm{~cm}^{-1}$ és koherens megvilágítás). Látható, hogy a lekerekített tárgyat extrém magas, $10^{10}$-en értéket megközelítő térbeli kontraszttal lehet leképezni. Ez az eredmény lényegesen 
jobb, mint az apodizációs szürőkkel elérhető eredmény és technikailag a megvalósítás is egyszerübb.

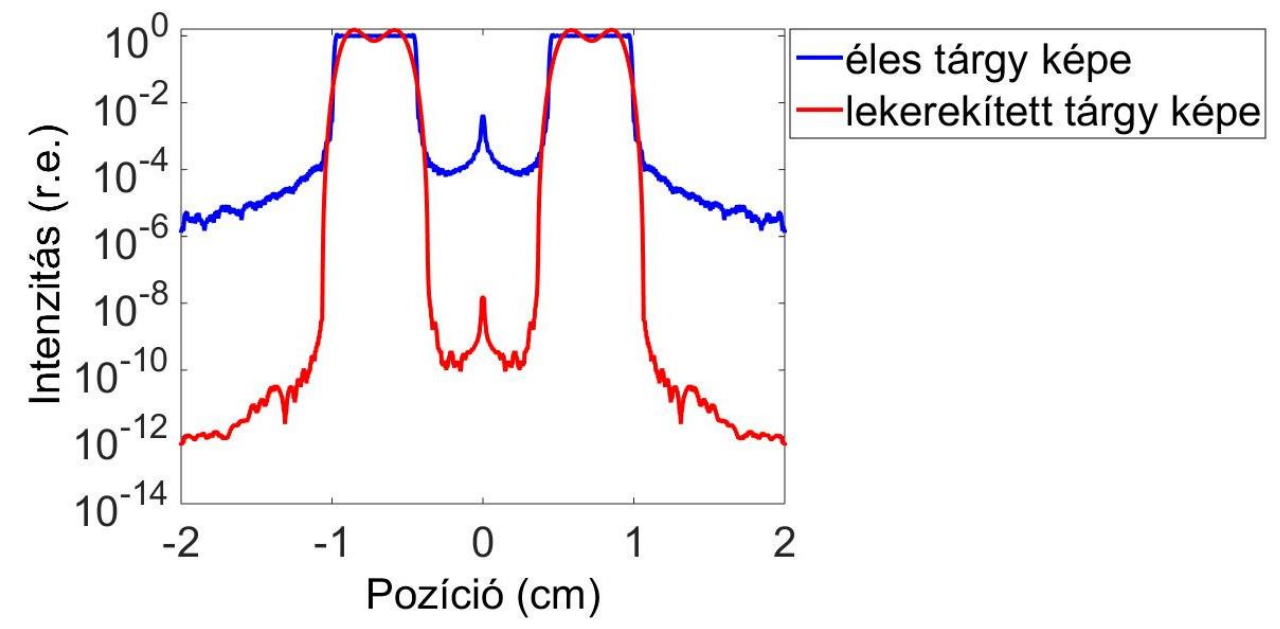

3-15. ábra

Az éles gyürü alakú tárgy (kék görbe) illetve a kis nyilásszögü elö-leképezéssel nyert lekerekitett tárgy (piros görbe) szimulált képsíkbeli intenzitáseloszlása. Szimuláció paraméterei; koherens megvilágítás, $f_{0}=500 \mathrm{~cm}^{-1}$ levágási frekvencia [118].

A 3-16. ábrán látható ugyanezen éles és lekerekített tárgyak leképezésének szimulációja inkoherens megvilágítás esetén. Látható, hogy inkoherens esetben a térbeli kontraszt javulásának mértéke jóval szerényebb. Azonban ez nem jelent jelentős megkötést, hiszen az elő-leképezés a kis nyílásszöge miatt eleve csak az ASE térben koherens részét engedi át. Tekintettel arra, hogy az alkalmazások többségénél csak a főimpulzussal azonos irányba terjedő ASE játszik szerepet, a számítások vonatkozásában a koherens fénnyel modellezett esetek tekinthetőek mérvadónak. A térben inkoherens részt egy klasszikus térszüréssel szeparálni lehet. 


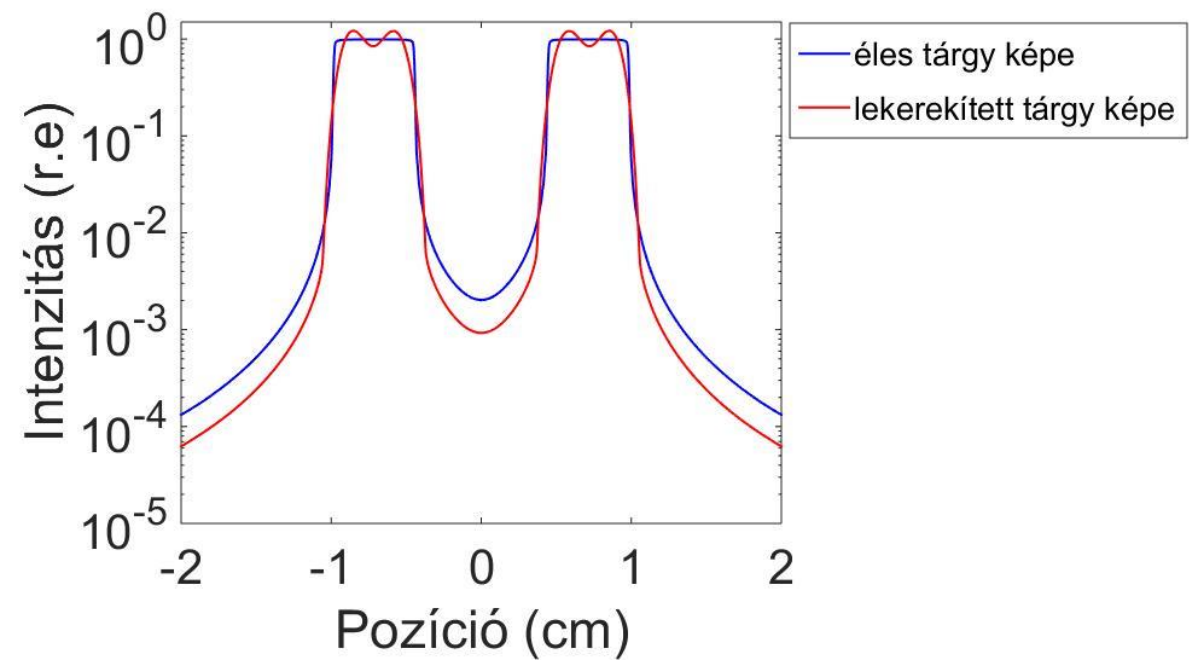

3-16. ábra

Az éles gyürü alakú tárgy (kék görbe) illetve a kis nyílásszögü elö-leképezéssel nyert lekerekitett tárgy (piros görbe) szimulált képsíkbeli intenzitáseloszlása. Szimuláció paraméterei; inkoherens megvilágitás; $2 f_{0}=1000 \mathrm{~cm}^{-1}$ levágási frekvencia.

A kis nyílásszögű leképezés kísérleti megvalósítása legegyszerübben (a több méter hosszú elrendezéseket elkerülendő) egy fókuszsíkban elhelyezett tülyukkal oldható meg. A tülyuk méretét úgy kell megválasztani, hogy a fókuszsíkbeli eloszlás első tíz mellékmaximumát engedje át. Mivel ez a szürési elrendezésben szereplő gázfelhőbe való fókuszáláshoz képest nagyobb beállítási pontosságot igényel, érdemesnek tartottam megvizsgálni a félreállított tűlyuk hatását a képkontrasztra. A 3-17. ábrán látható képsíkbeli eloszlás egy olyan félreállított esetnek felel meg, amikor az elő-leképezés Fourier-síkjának metszetében az egyik oldalon 5, a másik oldalon 15 mellékmaximumot engedünk át. Látható, hogy még egy ilyen relatíve durva félreállítás sem befolyásolja jelentősen a kép kontrasztját. 


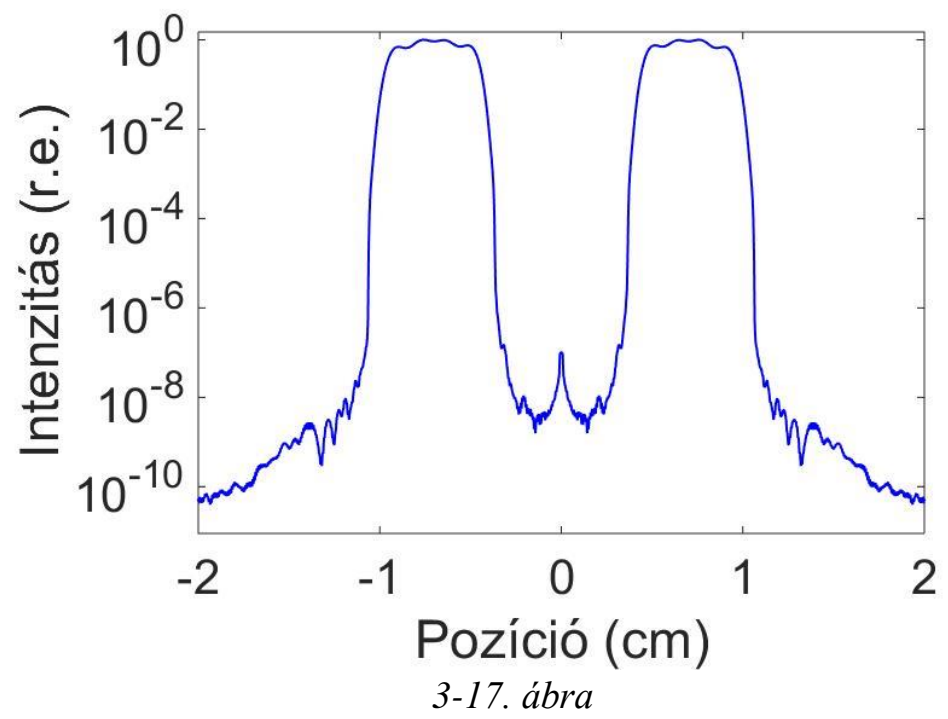

Egy félreállitott elö-leképezéssel nyert lekerekitett tárgy szimulált képsíkbeli intenzitáseloszlása (részletek lásd a szövegben). Szimuláció paraméterei; koherens megvilágítás; $f_{0}=500 \mathrm{~cm}^{-1}$ levágási frekvencia.

Az ebben a pontban bemutatott új tudományos eredményeket a leképezés kontrasztjára vonatkozó korlátozás és a különbözö típusú apodizációk és fázishibák szerepének azonositása valamint a tárgy térfrekvenciás modulációjának vizsgálata jelentették. A számítások egyszerü numerikus Fourier transzformációt és ablakfüggvényeket alkalmaznak, ami a leírásom alapján könnyen reprodukálható. Ennek okán és a disszertáció terjedelmének csökkentése érdekében eltekintettem a MATLAB kódoknak a dolgozatban való mellékelésétöl.

\section{2. d. Diszkusszió}

Ebben a fejezetben bemutattam az optikai leképező rendszerek térbeli kontrasztjának modellezésére szolgáló numerikus szimulációmat, amelyet hullámoptikai megközelítésre, azon belül pedig a térfrekvencia analízisre alapoztam. Megmutattam, hogy a kísérleti elrendezésnek megfelelő esetben a leképezés térbeli kontrasztja diffrakció-limitált esetben is alig haladja meg a $10^{3}$ értéket. A szimuláció szerint a leképezés f-számának növelésével javítható a térbeli kontraszt értéke, de az ezzel megjelenő leképezési hibák és a leképezéshez használt hullámhossz nagyságrendje a térbeli kontrasztra limitációt jelentenek. A pupillafüggvény apodizációja jelentős javulást eredményez a kép kontrasztjában, azonban kivitelezése technikailag nehéz. A leképező rendszer javítása helyett előnyösebbnek bizonyult a tárgy térfrekvenciás komponenseinek a manipulációja. A szóba jövő lehetőségek közül egy kis nyílásszögü elő-leképezéssel és a $10^{-3}$ intenzitásszint alatti részeket kitakaró apertúra kombinációjával előálló tárgy tünik a legkedvezőbbnek. 
Az elö-leképezés segítségével térfrekvencia-modulált tárgyat a számítások szerint extrém magas ( $10^{10}$-ent megközelítő) képkontraszttal lehet leképezni, ez kiemelten indokolttá teszi a kísérleti megvalósítását illetve további vizsgálatát. Erre az eredményre alapozva a további kutatásom iránya a leképező rendszerek képkontrasztjának több nagyságrendet átfogó kísérleti vizsgálata, továbbá ennek felhasználásával a nemlineáris Fourier-szürés által elérhető kontrasztjavulás kiterjesztése volt.

\subsection{A nemlineáris Fourier-szürő kontrasztjavításának kiterjesztése}

A 2. fejezetben bemutattam az elmélet szerint extrém magas időbeli és térbeli kontrasztjavulást eredményező nemlineáris Fourier-szürési technikát. A kísérleti tapasztalatok szerint az elérhető intenzitáskontraszt javulást - a nemlineáris kölcsönhatástól független - az elrendezés részét képező optikai leképezés térbeli kontrasztja korlátozza. Numerikus szimulációkra alapozva a 3.2. fejezetben megmutattam, hogy a képkontraszt javítás perspektivikus módja, ha a leképzendő tárgy térfrekvenciás spektrumát moduláljuk. Ennek eszköze lehet az, ha az éles (esetünkben gyürü alakú) tárgynak egy kis nyílásszögü előleképezéssel korlátozzuk a magas térfrekvenciás komponenseit és az így előálló lekerekített élekkel bíró kép $10^{-3}$ intenzitásszint alatti részeit egy második gyürü alakú apertúrával kitakarjuk. Az így előálló jórészt alacsony térfrekvenciás komponensekkel bíró, de nagy kontrasztú eloszlás szolgál új tárgyként, azaz a nemlineáris Fourier-szürés bemeneteként.

Ebben a fejezetben általánosan az optikai leképezés képkontrasztjának javításával kapcsolatos és a nemlineáris Fourier-szürési technika kontrasztjavításának vizsgálatára és annak kiterjesztésére kapott kísérleti eredményeimet mutatom be [118].

\section{3.a. Optikai leképezés kontrasztjának kísérleti javítása}

Mivel az optikai leképezés során mérni kívánt intenzitásarányok az 5-10 nagyságrendet közelítik, ezért a detektálás dinamikus tartományának növelése egy külön eljárást igényel. Az optikai leképezés térbeli kontrasztját egy speciálisan kialakított félvezető dióda lézerrel és detektor rendszerrel vizsgáltam meg. A kísérlethez fényforrásként egy kereskedelmi forgalomban kapható, a látható hullámhossz tartományban működő ( $\lambda=650 \mathrm{~nm})$ dióda lézert használtam, amely folytonos üzemmódú és teljesítménye a néhány mW nagyságrendjébe esik. Ennek a dióda lézernek a müködése egy 1,4 kHz-es frekvenciájú négyszögjellel volt modulálva a tápáramán keresztül. A detektáláshoz egy BPW21R típusú fotodiódát használtam, amelynek jele egy keskenysávú erősítőn volt átvezetve. Az erősített jel polaritását a fényforrás modulációjának ütemében váltogattuk, majd az így kapott jel egy integrátor 
bemenetére volt vezetve. Ezen technika előnye, hogy egy külső forrásból származó fény a periodikusan változó polaritás miatt az integrátor után zéró jelszintet eredményez. Ugyanakkor a polaritással egy ütemben modulált diódából érkező fény az integrátor után is mérhető. Egy ilyen frekvencia- és fázis-érzékeny detektálás az intenzitás mérés dinamikus tartományát több nagyságrenddel képes kiterjeszteni. Az optikai leképezés kontrasztját ezzel a fényforrás-detektor rendszerrel a 3-18. ábrán látható elrendezésben vizsgáltam.

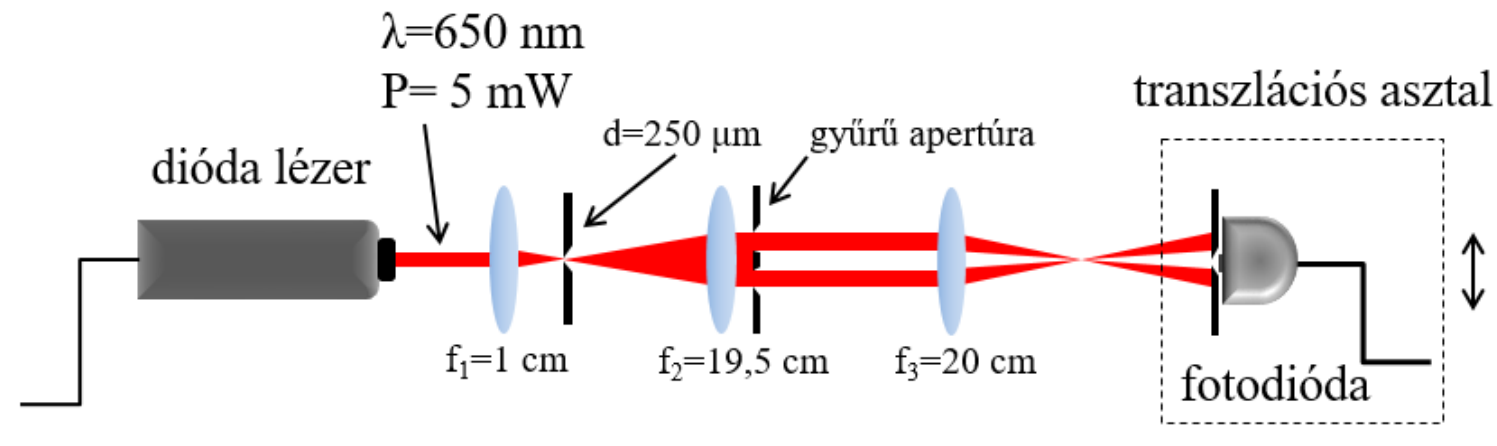

3-18. ábra

Az optikai leképezés térbeli kontrasztjának vizsgálatára használt elrendezés.

A dióda lézer nyalábprofilját egy klasszikus térszürési elrendezéssel a mérést zavaró térbeli modulációktól mentessé tettem. Az elrendezés egy $\mathrm{f}_{1}=1 \mathrm{~cm}$ és egy $\mathrm{f}_{2}=19,5 \mathrm{~cm}$ fókuszú lencsékből álló teleszkópból és a közös fókuszsíkban elhelyezett $250 \mu \mathrm{m}$ átmérőjü tülyukból állt. A párhuzamosító lencse után helyeztem el a $\mathrm{CaF}_{2}$ hordozóra ragasztott gyürü alakú apertúrát, melynek méretei $1,6 \mathrm{~cm}$ külső és $0,7 \mathrm{~cm}$ belső átmérő voltak. Az így keletkező tárgyat egy $\mathrm{f}_{3}=20 \mathrm{~cm}$-es fókuszú lencsével képeztem a detektorra közel $\mathrm{N}=1$ nagyítást alkalmazva. Ennek az optikai leképezésnek a levágási frekvenciája $\left(f_{0}=600 \mathrm{~cm}^{-1}\right)$ közel megegyezik a nemlineáris Fourier-szürésben alkalmazott leképezés levágási frekvenciájával. A detektor elé egy kis méretű $(\mathrm{d} \approx 0,5 \mathrm{~mm})$ íriszt helyeztem el, mellyel a képsíknak mindig csak egy adott pontját vizsgáltam. A térbeli feloldást az írisz mérete szabta meg. A detektor az optikai tengelyre merőleges irányú eltolón volt rögzítve, ennek segítségével rögzítettem a kép intenzitás eloszlását. A 3-19. ábrán a mért képsíkbeli normált intenzitáseloszlás metszete látható. 


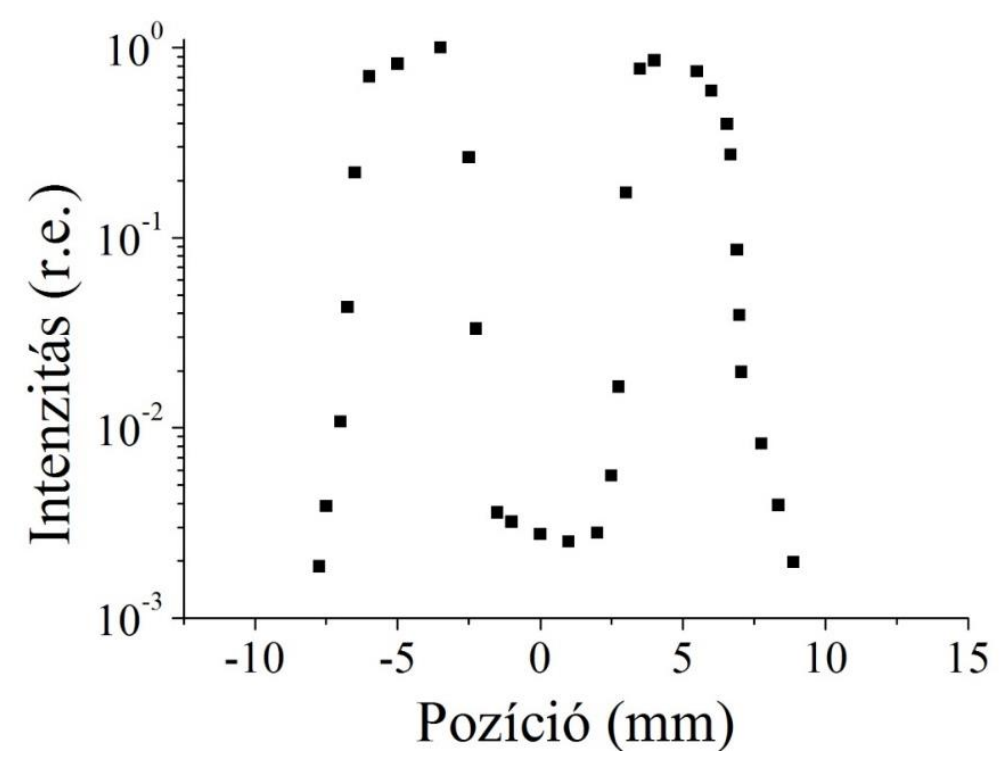

3-19. ábra

A gyürü alakú tárgy képének intenzitáseloszlása $f_{0}=600 \mathrm{~cm}^{-1}$ levágási frekvenciájú optikai leképezés esetén. (A detektor térbeli feloldása $d=0,5 \mathrm{~mm}$.)

Látható, hogy a képsíkban a gyürü közepén a kontraszt 2,5 nagyságrendet ér el. Ez az érték kisebb, mint amit a modellezés az ideális diffrakció-limitált leképezés esetére jósolt koherens esetben. Az eltérést a leképezési hibák, a fényforrás térbeli koherenciája és az optikai elemeken fellépő szórás okozhatták.

A gyürüélek - elő-leképezéssel történő - lekerekítésének hatását a 3-20. ábrán látható elrendezéssel vizsgáltam. Az $\mathrm{f}_{3}=20 \mathrm{~cm}$-es lencse utáni fókuszsíkba egy $100 \mu \mathrm{m}$ átméröjü tülyukat helyeztem el. Ez az elrendezés a modellezésnek megfelelően a Fourier-eloszlás közepének 10 mellékmaximumát engedi át. A tülyuk után a nyalábot egy $\mathrm{f}_{4}=19 \mathrm{~cm}$-es lencsével párhuzamosítottam és utána helyeztem el a második gyürű alakú apertúrát, amelynek belső átmérőjét 1mm-rel kisebbre választottam, mint az első gyürüét. Az így kapott tárgyat egy $\mathrm{f}_{5}=18 \mathrm{~cm}$-es lencsével képeztem le $\mathrm{N}=1$-es nagyítással. Ezen második leképezés köztes fókuszsíkjában az optikai rendszerben lévő számos elem miatt egy apertúrát helyeztem el, ami a leképezést nem érinti, de az esetleges parazita reflexiókat kiszüri. A detektorral mérve a gyürü közepén a kép kontrasztja meghaladta a $10^{5}$-en szintet. Ez jelentős javulás a korábbi 2-3 nagyságrendhez képest. A kapott érték azonban nagyságrendekkel elmarad a numerikus szimulációval kapott eredménytől. 


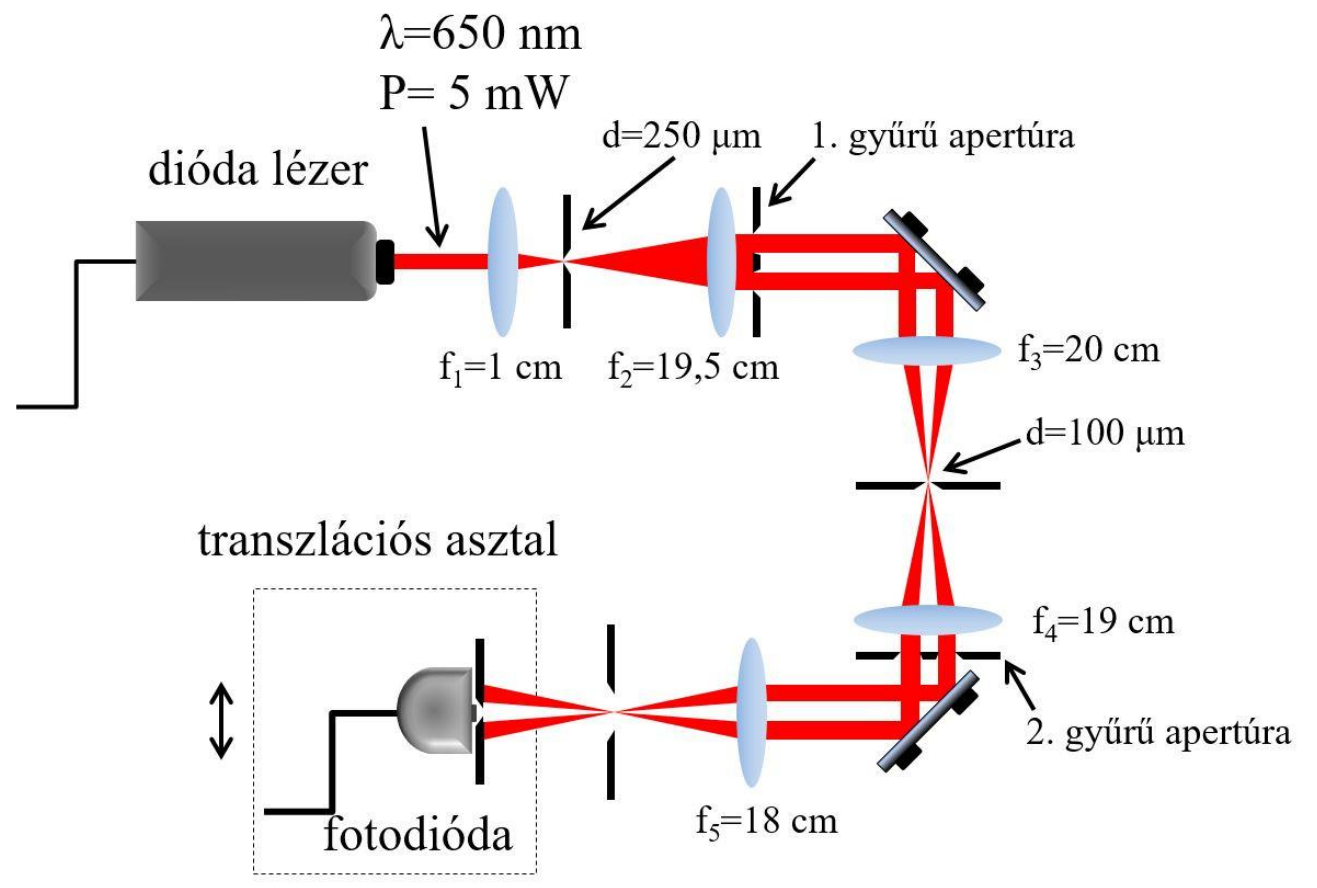

3-20. ábra

A gyürü alakú tárgy térfrekvenciás komponenseit egy kis nyilásszögü elö-leképezés és egy második apertúra modulálja. Az így elöálló eloszlást az $f_{5}$ lencse képezi le fotodiódára.

A leképezés kontrasztjának pontosabb mérése érdekében a 3-20. ábrán látható elrendezést kiegészítettem egy $\mathrm{f}_{6}=13,5 \mathrm{~cm}$-es lencsével, ami a kép belső sötét részét egy 1 mm-átmérőjü tülyukon át képezi le a detektorra. A tűlyuk - a relatíve nagy mérete miatt - csak azokat a fénysugarakat blokkolja, amely a nyalábhoz képest jelentősen eltérő térszögben terjednek, így a leképezést nem befolyásolja, ugyanakkor a szórás és egyéb reflexiók hatását csökkenti. Ezzel az elrendezéssel a képsíkbeli gyürü közepének frekvencia- és fázis-érzékeny detektor által mért jelszintje nem érte el a zajszintet, ami a mérésnél $2 \mathrm{mV}$ alatti érték volt. A leképezés kontrasztja meghaladta a mérőrendszer dinamikus tartományát. A detektor maximális jelszintje (a gyürü apertúrák kivételével) az elrendezésre nézve $200 \mathrm{mV}$ értékü volt $10^{-5}$ szürés mellett. Ez azt jelenti, hogy a leképezés kontrasztja biztosan meghaladja a $10^{7}$ értéket.

A fenti kísérleti elrendezéssel tehát sikerült egy kis nyílásszögü elö-leképezéssel a gyürű alakú tárgy térfrekvenciás komponenseit úgy modulálni, hogy ezt egy relatíve nagy fszámú optikai leképezés is extrém magas $\left(10^{7}-t\right.$ meghaladó) kontraszttal képezze le. A kísérleti eredmény a numerikus szimuláció eredményét jól közelíti. A leképezés kontrasztjának pontos értékét a korlátozott mérési tartomány miatt nem lehetett pontosan megállapítani. Ultraibolya rövid impulzusok esetén a leképezés kontrasztjának mérése még 
nagyobb kihívás, hiszen itt nem áll rendelkezésre frekvencia és fázis-érzékeny detektálási lehetőség.

\section{3.b. A nemlineáris Fourier-szüréssel elérhető kontrasztjavulás kísérleti vizsgálata}

A nemlineáris Fourier-szürés kísérleti vizsgálatához a korábban tárgyalt festék-excimer lézerrendszert használtam. Ennek sematikus rajza a 3-1. ábrán látható. Ezen elrendezésben a frekvenciakétszerezés után a rövid impulzus kétszeri áthaladás során erősödik egy $\mathrm{KrF}$ erősítőben. A lézerrendszer kimenetén így 500 fs hosszúságú és 10 mJ energiájú impulzusok állnak rendelkezésre 1 és $10 \mathrm{~Hz}$ közötti ismétlési frekvencia mellett.

A gázfelhővel történő kölcsönhatás egy vákuumkamrában történt, jellemzően $10^{-2}$ mbar levegőnyomás mellett. A kísérlet során >99,99\% tisztaságú Ar nemesgázt használtam a fókuszsíkban lezajló kölcsönhatáshoz. A gáz befecskendezését egy Parker VAC-750 típusú mágnesszeleppel szabályoztam. A mágnesszelep elött az Ar gáz nyomását egy reduktor szeleppel változtattam. A mágnesszelep vezérlő egység indítójelével - egy állítható késleltető egység közbeiktatásával - indítottam a lézert ezáltal biztosítva a szinkronizációt. A mágnesszelep után egy 0,6 mm átmérőjü fúvóka formálta a gázfelhőt. A kísérlethez felépített nyalábút sematikus rajzát a 3-21. ábra mutatja.

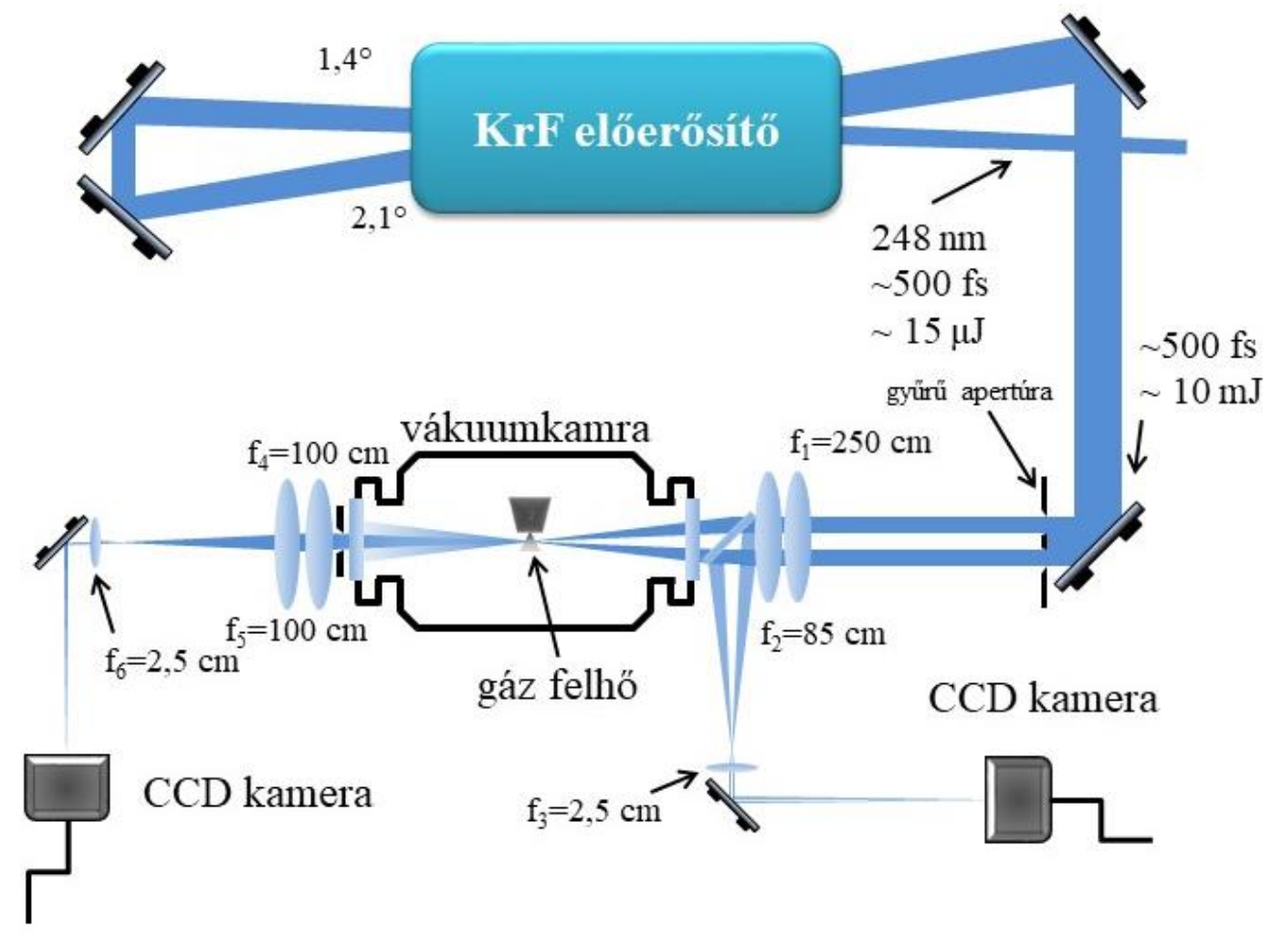

3-21. ábra

A nemlineáris Fourier-szürés kísérleti vizsgálatához használt optikai elrendezés sematikus rajza. 
A gyürü alakú eloszlást egy $5 \mathrm{~mm}$ vastag $\mathrm{CaF}_{2}$ szubsztrátra ragasztott apertúra állította elö. Az így formált gyürü külső átmérője $1,6 \mathrm{~cm}$, belső átmérője $0,7 \mathrm{~cm}$ volt. A kísérlet során egy $\mathrm{f}_{1}=250 \mathrm{~cm}$ és egy $\mathrm{f}_{2}=85 \mathrm{~cm}$ fókusztávolságú lencse kombinációját alkalmaztam lefókuszáláshoz. A fókuszsík és az $\mathrm{f}_{2}$ lencse közötti távolság $73 \mathrm{~cm}$ volt. Mivel a nyaláb fókuszsíkbeli eloszlása döntő jelentőséggel bír a szürt nyaláb eloszlására (a kimeneti képre), ezért a fókuszsíkot egy $\mathrm{f}_{3}=2,5 \mathrm{~cm}$-es gyüjtőlencsével egy Hamamatsu C7040 típusú CCD detektorra képeztem le. A leképezés során $\mathrm{N}=30$-as nagyítást alkalmaztam. A fókuszsíkbeli eloszlás egy jellemző felvétele 3D-s ábrázolásban a 3-22. ábrán látható. A fókuszfolt mérete a (gyürü alakú nyalábra vonatkozó) diffrakció-limitált határérték 1,75-szerese. Az eloszlás alakja reguláris és lövésről lövésre stabilnak bizonyult, ezért a kísérlet során nem tartottam szükségesnek a folyamatos monitorozást.

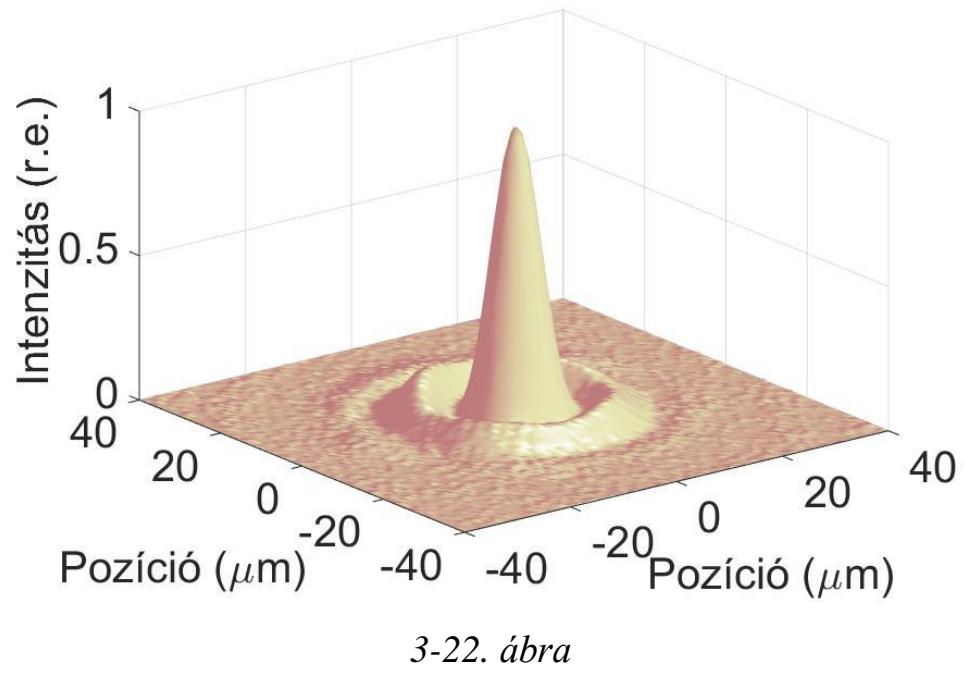

A nemlineáris Fourier-szürés bemenö gyürü alakú nyalábjának fókuszsíkbeli eloszlása f/35-ös fókuszálás mellett [118].

Ahogy a 2.3.i. pontban bemutattam, a numerikus szimuláció szerint az elrendezés az időbeli kontrasztjavításon túl a nyaláb magas térfrekvenciás komponenseit is szüri. A fókuszsíkban lezajló nemlineáris folyamatok, mint az önfókuszálodás/filamentáció és csatornázódási jelenségek azonban negatív hatással is lehetnek a nyaláb térbeli tulajdonságaira. A nemlineáris Fourier-szürésnek a nyaláb térbeli tulajdonságaira gyakorolt hatása igen fontos a nyaláb további alkalmazhatósága szempontjából. Ehhez a kimenő oldalon elhelyezett apertúra után egy $\mathrm{f}_{4}=100 \mathrm{~cm}$-es gyüjtőlencsével először párhuzamosítottam, majd egy $\mathrm{f}_{5}=100 \mathrm{~cm}$-es lencsével fókuszáltam a szürt nyalábot. A fókuszsíkot egy $\mathrm{f}_{6}=2,5 \mathrm{~cm}$-es lencsével képeztem a Hamamatsu C7040 típusú CCD kamerára N=38-as nagyítás mellett. A CCD kamerára eső intenzitást egy $0,1 \%$ transzmissziójú dielektrikum tükör és szürkeszürök behelyezésével 
csökkentettem. A 3-23. ábrán látható egy tipikus eloszlás 3D-s ábrázolásban a nagyítás értékével korrigált hosszskála mellett. Az eloszlás szabályos Gauss függvényt követ és a félértékszélessége az elméleti határ 1,75-szerese, azaz megegyezik a bemenő oldalon mért értékkel. A számítások során a szürő kimenetén megjelenő csonkolt Gauss eloszlást teljes Gauss eloszlással közelítettem.

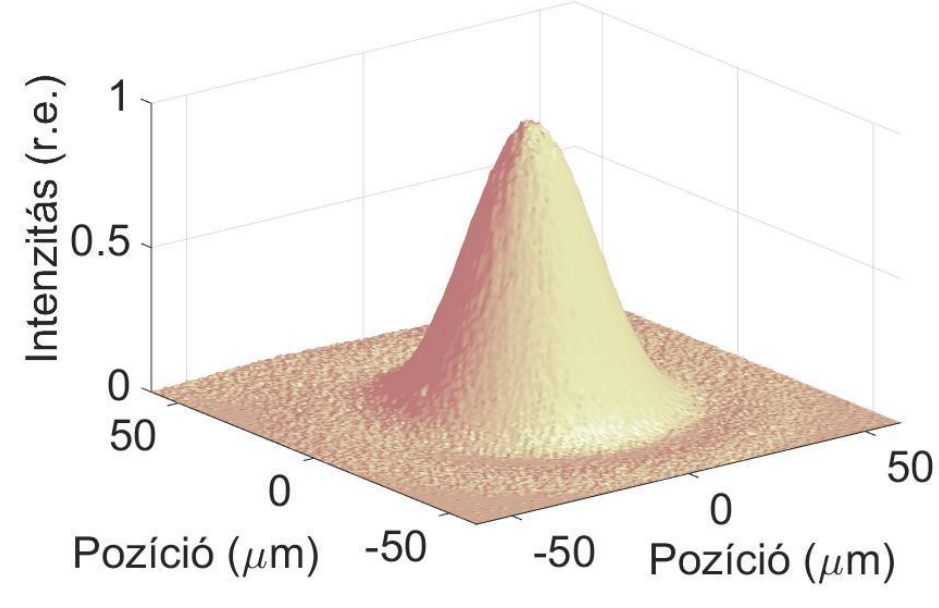

3-23. ábra

A nemlineáris Fourier-szürés kimeneti nyalábjának fókuszsíkbeli eloszlása (f/140-es

fókuszálás mellett) [118].

A szürési elrendezés által elérhető időbeli kontrasztjavulást a nagyjelü és a kisjelü transzmisszió hányadosa szabja meg. Ennek vizsgálata érdekében úgy módosítottam a kísérleti elrendezést, hogy a belépő és a kilépő nyaláb energiáját egyidejüleg lehessen mérni (lásd 3-24. ábra). A bemenő energia monitorozásához az $\mathrm{f}_{1}=250 \mathrm{~cm}$-es lencséről való (közel $0^{\circ}$-os) reflexiót használtam fel és egy ITL gyors vákuum fotodióda segítségével mértem a reflektált jelet. A fotodióda által mért feszültségértéket egy GENTEC QE50PL-S-MD-D0 energiamérő fej segítségével hitelesítettem. A vákuumkamra kilépő oldalán (a gyürü alakú tárgyról az $\mathrm{f}_{1}$ és $\mathrm{f}_{2}$ lencse által alkotott kép síkjában) egy íriszt helyeztem el, amellyel csak az eredeti gyürű alakú eloszlás közepét engedtem át. Az írisz után egy $\mathrm{f}_{3}=15 \mathrm{~cm}$ fókuszhosszú lencsével egy $\mathrm{d}=250 \mu \mathrm{m}$ átmérőjü tülyukon fókuszáltam át a nyalábot és egy Hamamatsu R1193U-52 típusú fotodiódával mértem a jelet. A fotodióda jelét ebben az esetben egy nagyobb érzékenységü GENTEC QE12SP-S-MT energiamérő fejjel hitelesítettem. A tülyukon való átfókuszálásra azért volt szükség, hogy a fotodiódával a rövid jellel egy irányba terjedő sugárzás energiáját mérjem. 


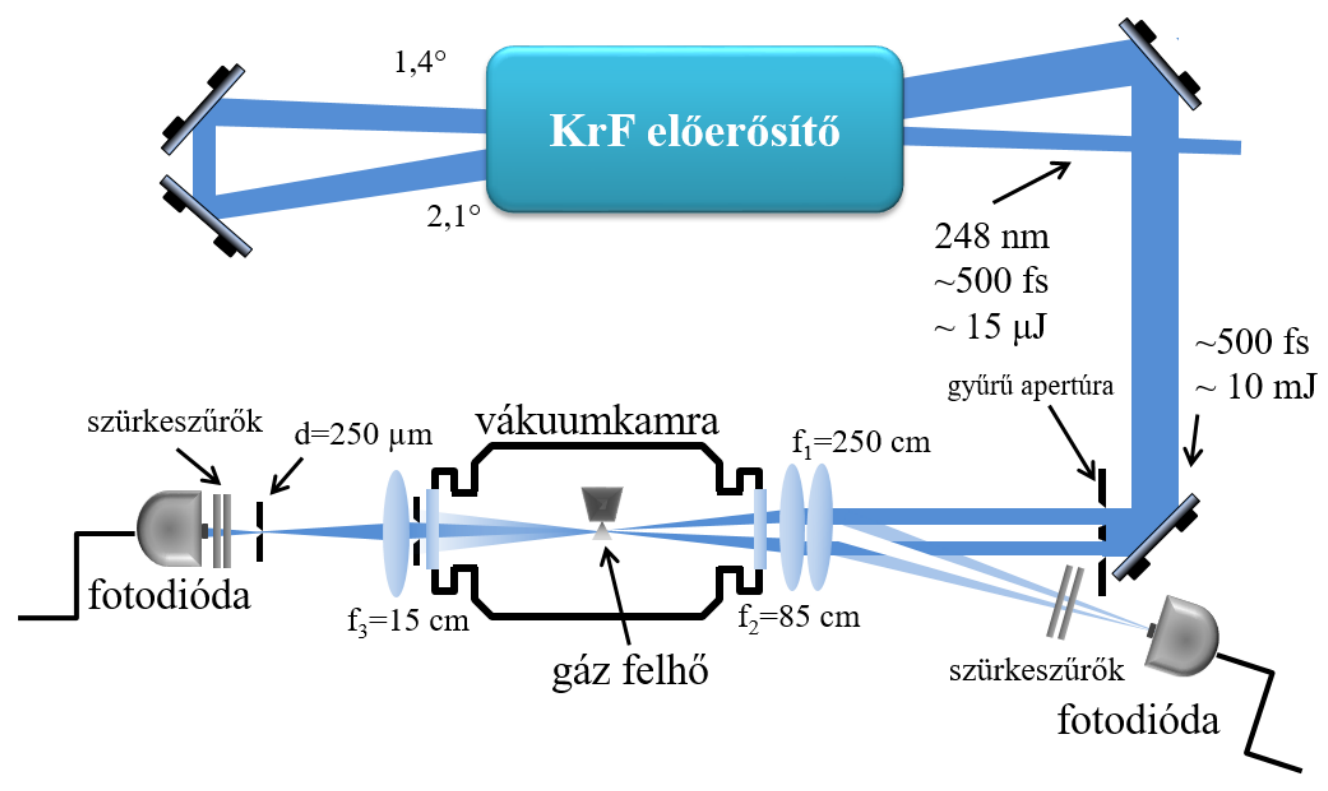

3-24. ábra

A nemlineáris Fourier-szürés intenzitásfüggő transzmissziójának méréséhez használt kisérleti elrendezés rajza.

A bemenő oldalon a nyalábot (közel $0^{\circ}$-ban betett) kvarclapok, dielektrikum alapú attenuátor és szürkeszürök behelyezésével 3 nagyságrenden át gyengítettem. Egy adott gyengítés esetén mindig $\sim 15 \mathrm{db}$ összetartozó bemenő és kimenő energia értéket rögzítettem. Az így kapott adatokat ábrázoltam a 3-25. ábrán látható grafikonon, ahol az elrendezés transzmissziója (a kimenő és a bemenő energia hányadosa) a fókuszsíkbeli intenzitás függvényében látható. A grafikonon látható mérési pontokat az ugyanazon gyengítésnél mért értékek átlaga adja, minden így kapott pontnál feltüntettem a mérés hibáját is.

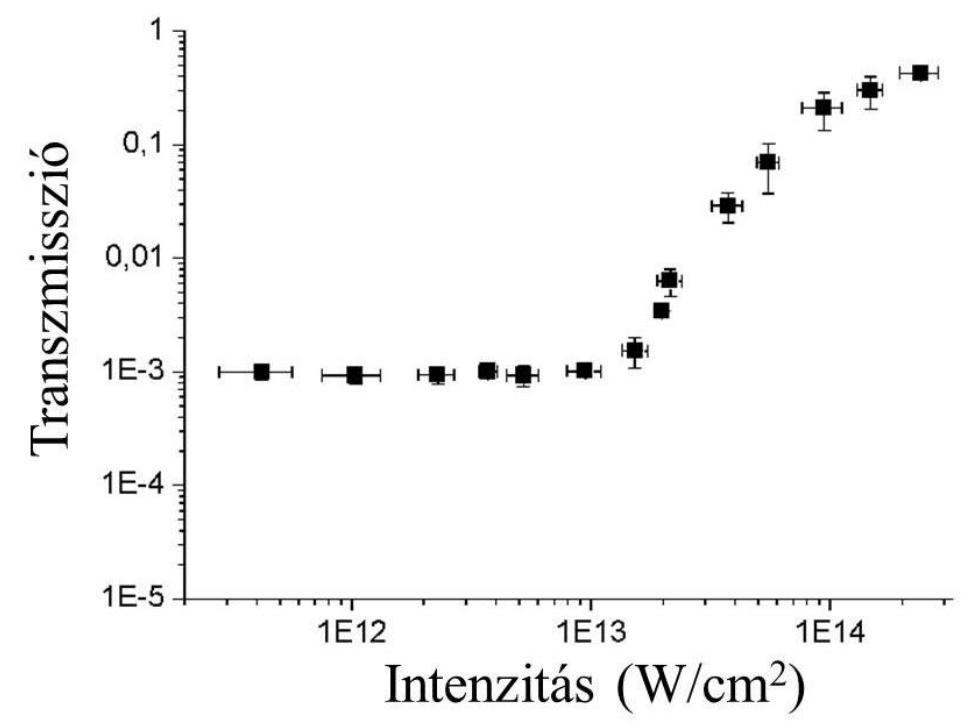

3-25. ábra

A nemlineáris Fourier-szürés transzmissziója a fókuszált intenzitás függvényében. 
A 3-25. ábráról jól látható, hogy a maximális intenzitásnál $\left(>2 \cdot 10^{14} \mathrm{~W} / \mathrm{cm}^{2}\right)$ az energia transzmisszió értéke meghaladja a 40\%-ot, továbbá a fókuszsíkbeli intenzitás csökkentésével a szürési elrendezés transzmissziója - egyre nagyobb - meredekséggel csökken egészen addig, míg el nem éri a korábban [38]-ban leírt $10^{-3}$-on értéket. Ezen érték elérése után az intenzitástól függetlenül a transzmisszió konstans marad. A kísérletek tanulsága szerint ez a limit valóban nem a fókuszsíkban lezajló nemlineáris kölcsönhatás következménye, ugyanis ez a háttérszint akkor is megmaradt, ha nem juttattam gázt a kamrába. Ebből az következik, hogy a hátteret, csak az optikai elemeken fellépő szórás és a fókuszáló lencse nem tökéletes leképezése okozhatja. Ez az eredmény megerősíti a [38]-ban kapott korábbi eredményt.

A továbbiakban az optikai leképezés által okozott limit kiterjesztésével kapcsolatos kísérleti eredményeimet mutatom be.

\section{3.c. Az elérhető kontrasztjavulás növelésének kísérleti vizsgálata}

A leképezés térbeli kontrasztjavításának rövid ultraibolya impulzusokra való vizsgálatát ugyancsak a korábban bemutatott festék-excimer lézerrendszerrel végeztem. A kontraszt javításához szükséges elő-leképezést egy vákuumkamrában elhelyezett tülyuk segítségével hajtottam végre. A kísérleti elrendezés vázlata a 3-26. ábrán látható. A lézerrendszerből kilépő nyaláb útjába helyeztem az első gyürü alakú apertúrát $0,7 \mathrm{~cm}$ belső és $1,6 \mathrm{~cm}$ külső átmérővel. Ezt a tárgyat egy két lencséből álló $\left(\mathrm{f}_{1}=200 \mathrm{~cm}\right.$ és $\left.\mathrm{f}_{2}=100 \mathrm{~cm}\right) 67 \mathrm{~cm}$-es eredő fókuszú optikai rendszerrel képeztem le $\mathrm{N}=1$-szeres nagyítás mellett, úgy hogy a köztes fókuszsíkba helyeztem a vákuumcsőben rögzített tülyukat. A nyalábot a tủlyukon való áthaladás után a képsík előtt néhány cm-el egy ugyancsak két lencséből álló rendszerrel $\left(\mathrm{f}_{3}=200\right.$ és $\left.\mathrm{f}_{4}=100 \mathrm{~cm}\right)$ kollimáltam. A kollimálás után helyeztem el a második gyürü alakú apertúrát (belső átmérő $0,6 \mathrm{~cm}$, külső átmérő $1,7 \mathrm{~cm}$ ). Az így keletkezett nyaláb jelenti a bemenetet a nemlineáris szürési elrendezésnek. A megnövekedett számú optikai elem miatt a korábbi kísérleti elrendezéshez képest csökkent a nyaláb energiája, így ugyanakkora nyílásszögü fókuszálás mellett csak kisebb fókuszsíkbeli intenzitást lehet elérni. Ezt ellensúlyozandó csökkentettem a nyílásszöget és egy $\mathrm{f}_{5}=50 \mathrm{~cm}$-es lencsével végeztem a lefókuszálást/leképezést. A képsíkban egy íriszt, helyeztem el, ami a gyürü eloszlásnak csak a közepét engedi csak át. Hasonlóan a látható optikai tartományban végzett méréshez, az írisz után egy $\mathrm{f}_{6}=15 \mathrm{~cm}$-es lencsével egy $250 \mu \mathrm{m}$ átmérőjü tủlyukon fókuszáltam át a nyalábot. A tülyuk - a nagy mérete miatt - csak a nyalábhoz képest lényegesen eltérő térszögben terjedő 
fényt blokkolja. A tülyuk mögött egy Hamamatsu R1193U-52 típusú diódával mértem a jel energiáját.

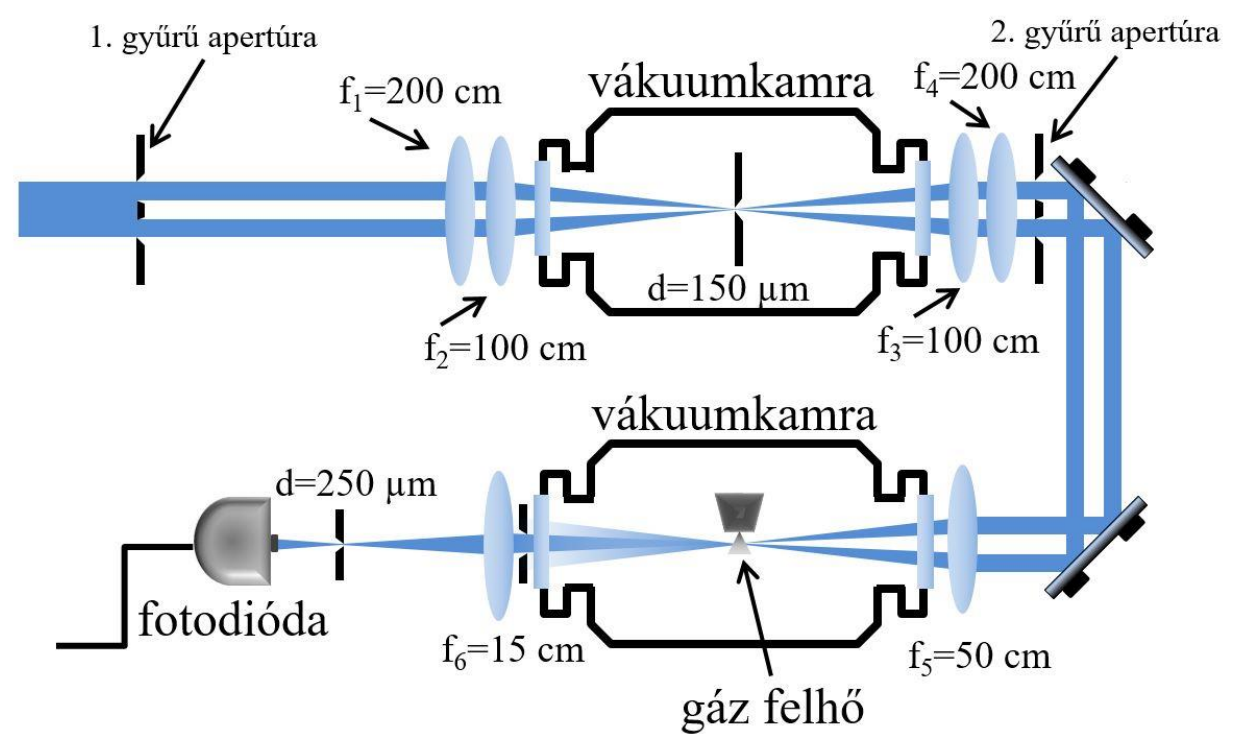

3-26. ábra

A kis nyilásszögü elö-leképezéssel kiegészitett nemlineáris Fourier-szürés kisérleti elrendezése.

Mint ismeretes a rövid impulzusú KrF excimer lézerrendszerek esetében a 248 nm-es központi hullámhossz miatt komoly problémát jelent az optikai elemeken fellépő energiaveszteség. Ez egyrészt a fókuszált intenzitást (ezáltal a nemlineáris effektus bekövetkezését), másrészt a fotodióda mérési tartományát limitálja. A fenti elrendezésben nem sikerült megközelíteni a korábban tapasztalt közel 40\%-os transzmissziót a rövid jelre nézve, a leképezés vizsgálatára azonban alkalmas volt. A leképezés kontrasztjának mérése során a gyürü közepébe eső ASE és rövid jel intenzitása is a zajszint alá esett. A fenti mérési elrendezésben a fotodióda rövid UV impulzusokra vonatkozó dinamikus tartománya $2,5 \cdot 10^{4}$ értékü volt. Ez alapján az elrendezéssel elérhető kontrasztjavulását nagyobb, mint $2,5 \cdot 10^{4}$-re becsültem, ami több mint egy nagyságrenddel nagyobb, mint a korábban kapott $10^{3}$ érték.

A kontrasztjavulást elsődlegesen meghatározó ASE esetében alacsonyabb volt a dinamikus tartomány a 3-26. ábrán látható mérési elrendezésben. A fenti $2,5 \cdot 10^{4}$-es becslést a rövid jelre mért képkontrasztra alapozva tettem feltételezve, hogy az ASE leképezési tulajdonságai megegyeznek a rövid jelével. Ez a feltételezés megalapozottnak tünik mivel a nemlineáris szürés előtt lévő klasszikus térszürés jó közelítéssel csak a rövid jellel egy irányba terjedő ASE-t engedi át. Ugyanakkor ennek igazolására szükségesnek tartottam a leképezés ASE-ra vonatkozó kontrasztjának nagyobb dinamikus tartományon való 
tanulmányozását is, amelyet a 3-27. ábrán látható mérési elrendezéssel végeztem el. Ez az elrendezés nagyban hasonlít a 3-26. ábrán bemutatotthoz, annyi különbséggel, hogy az ASE-t egy klasszikus excimer lézer fényével modelleztem. A lézerrendszer $\mathrm{KrF}$ excimer erősítője köré egy rezonátort építettem, ahol a záró tükör 100\%-os, a kicsatoló tükör pedig 8\%-os reflexiójú volt. Egy $\mathrm{KrF}$ excimer lézer impulzusainak időbeli lefutása jól közelíti az erősített spontán emissziójét, de az impulzusok által hordozott energia több nagyságrenddel is nagyobb lehet. A kísérleti elrendezésben lévő térszürés biztosítja, hogy ugyanarra a térszögre eső jelet vizsgáljuk, mint a korábbi esetben. (A nemlineáris szüréshez tartozó leképezés nyílásszögét a korábbi kísérleti elrendezéshez igazítottam.)

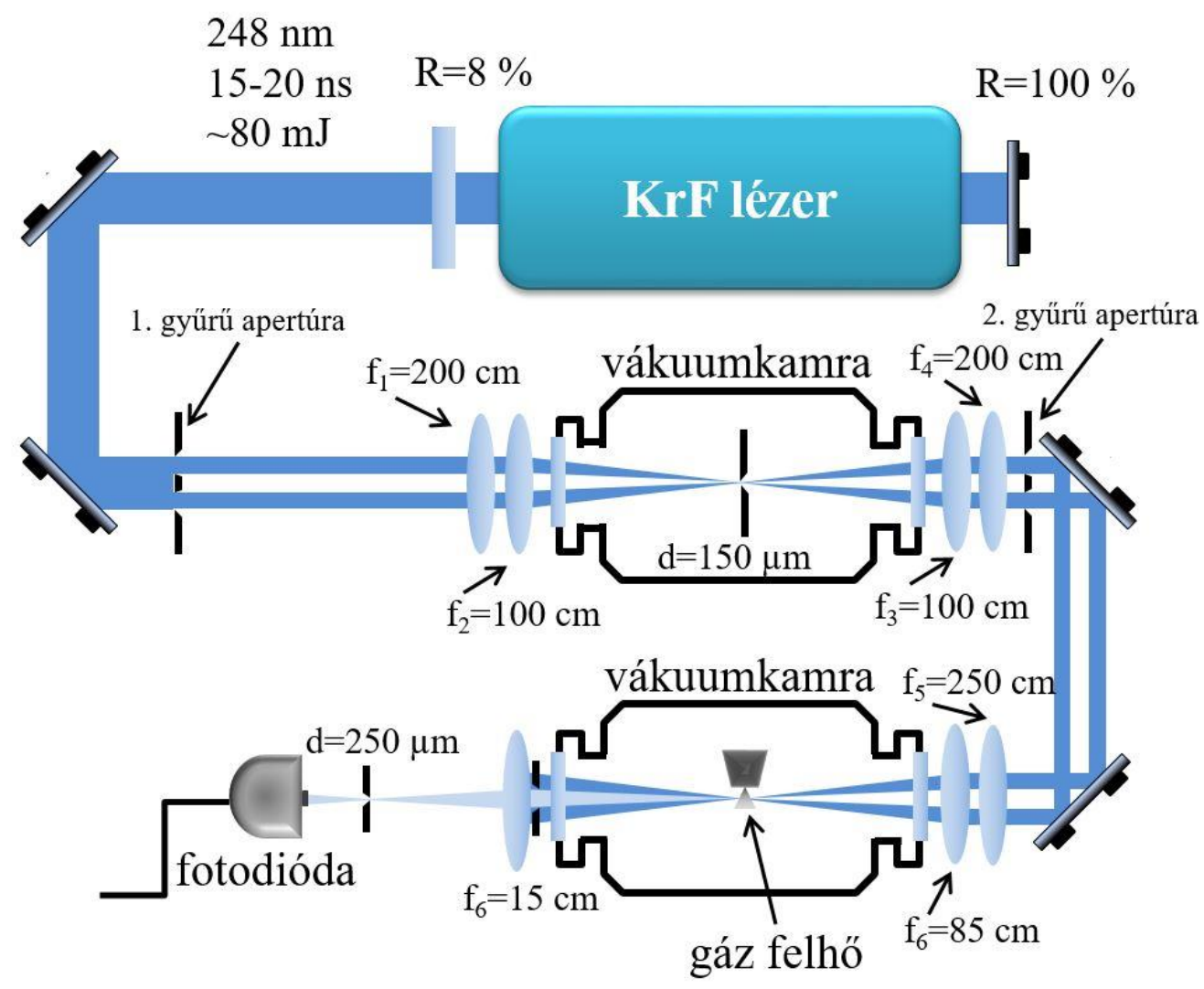

3-27. ábra

Az optikai leképezés kontrasztját az erösitett spontán emisszióra (ASE) modellezö kísérleti elrendezés rajza.

Az így módosított kísérleti elrendezéssel az ASE-vel mérhető leképezés kontrasztjára kapott értéket, ugyancsak a mérörendszer méréshatára szabta meg, ami az adott elrendezésben 2,5 $\cdot 10^{4}$ értéket jelentett. A mérés tartományát tehát sikerült kiterjeszteni az időbeli háttérre vonatkozóan. Ezzel megerősítettem a korábbi feltételezést, hogy a fókuszsíkban lezajló nemlineáris kölcsönhatásnak nincs hatása a kimeneten mérhető háttérre, ugyanis a gázfelhő jelenlétével és a nélkül is ugyanazt az eredményt kaptam. 
A fenti eredményekre alapozva mindenképp szükségesnek tartottam az elő-leképezéssel kiegészített szürési elrendezés energia transzmissziójának kimérését az intenzitás függvényében. Ez a kísérleti elrendezés megnövekedett energiaigénye miatt csak nagyobb előzetes erősítéssel lehetséges. Az energia növelésének egyik lehetséges módja, hogy a szürési elrendezés előtt kettőnél több átmenetben erősítem a nyalábot. A KrF erősítő közeg erősítési tulajdonságai miatt (amit a telítődő erősítés és nem telítődő abszorpció határoz meg), egy adott keresztmetszetü erősítőben még a döntött tengelyü erösítés alkalmazásával sem lehet 3-nál nagyobb számú átmenetet megengedi az ASE drasztikus növekedése nélkül [78]. A kísérlethez használt lézerrendszerben ennek megfelelően az erősítési átmenetek szögét $1,4^{\circ}$ $2,2^{\circ}$ és $2,8^{\circ}$ nak választottam.

A kísérleti elrendezés sematikus rajza a 3-28. ábrán látható. Az elrendezés hosszának csökkentése érdekében a harmadik erősítési átmenet az elő-leképezésnek részét képezi. Azaz az első gyürü alakú apertúra a második ás harmadik átmenet közé volt elhelyezve. A lézerrendszer kimenetén egy $\mathrm{f}_{1}=250 \mathrm{~cm}$ és egy $\mathrm{f}_{2}=200 \mathrm{~cm}$-es lencse kombinációja képezi le az első gyürü apertúrát. A lencserendszer kísérletileg mért eredő fókusza $120 \mathrm{~cm}$ volt. A köztes fókuszsíkba egy $150 \mu \mathrm{m}$ átmérőjü vákuumtérbe helyezett tülyuk korlátozza a leképezés nyílásszögét. A térszürést követően közvetlenül a képsík előtt egy $\mathrm{f}_{3}=120 \mathrm{~cm}$-es fókuszú lencse párhuzamosítja a nyalábot. Az elő-leképezés képsíkjába helyeztem a második gyürü alakú apertúrát. A korábbi elrendezésekhez hasonlóan az így kapott nyalábeloszlás jelenti a bemenetet a nemlineáris Fourier-szürésnek. A szürési elrendezésben egy $\mathrm{f}_{4}=85 \mathrm{~cm}$ fókuszhosszal bíró lencse fókuszálja a gázfelhőbe a nyalábot. A kimeneten (a fókuszáló lencse által a második gyürü alakú apertúráról képzett képsíkban) egy íriszt helyeztem el, ami az eredeti gyürü alakú nyalábeloszlás közepét engedi csak át. Az írisz után a korábbiakhoz hasonló módon egy f $f_{5}=27 \mathrm{~cm}$-es fókuszú lencse egy $250 \mu \mathrm{m}$ átmérőjű tülyukon fókuszálja át a nyalábot, ezáltal kiszürve a főimpulzussal nem egy irányba terjedő fényt. A jel detektáláshoz ugyancsak a Hamamatsu R1193U-52 típusú fotodiódát használtam. 


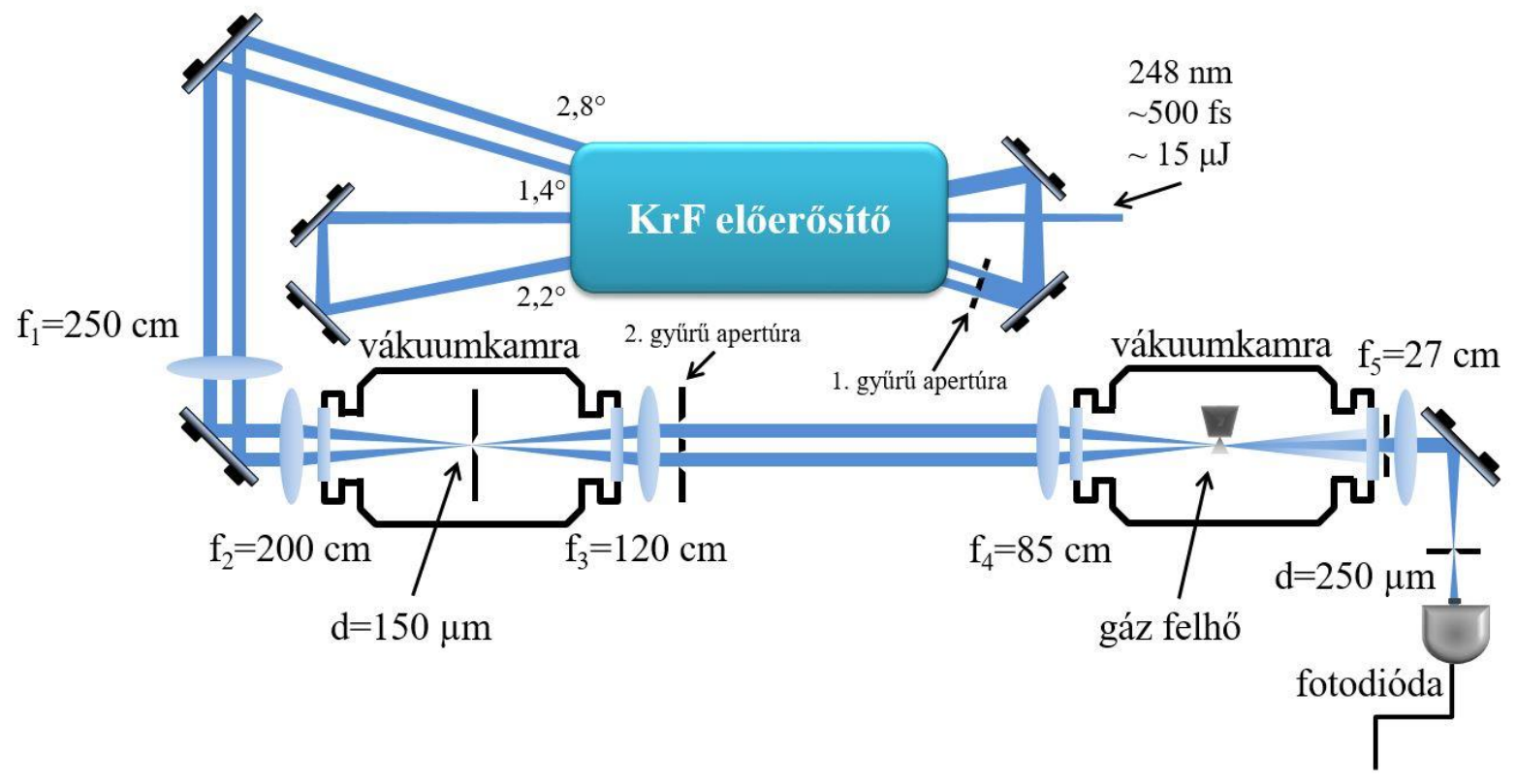

3-28. ábra

A kis nyilásszögü elö-leképezéssel kiegészitett nemlineáris Fourier-szürés intenzitásfüggö transzmisszió méréséhez használt kísérleti elrendezés rajza.

A bemenő energia méréséhez az $\mathrm{f}_{3}$ lencse elé helyeztem el egy kvarclapot közel $0^{\circ}$-os beesési szögben (a 3-28. ábrán ez nincs jelölve). Az erről az elemről való reflexiót egy ITL típusú gyors vákuum fotodióda mérte. A fotodiódák hitelesítését egy GENTEC QE50PL-SMD-D0 energiamérő fej segítségével végeztem. A bemenő energia gyengítését a korábbi méréshez hasonlóan vékonyréteggel bevont dielektrikumok és szürkeszürők behelyezésével végeztem. A korábbi méréshez hasonlóan összetartozó bemenő illetve kimenő energia párokat mértem, továbbá adott gyengítés esetén több lövést rögzítettem. Egy adott gyengítéshez tartozó mérések átlaga felel meg egy pontnak a grafikonon. Ez az eljárás lehetőséget adott az egyes mérési pontok hibájának meghatározására melyet feltüntettem a grafikonon. A fókuszsíkban elérhető maximális intenzitás a lézerrendszerben megnövelt erősítési átmenetek ellenére sem érte el az optimumnak tekinthető néhányszor $10^{14} \mathrm{~W} / \mathrm{cm}^{2}-\mathrm{t}$; az elérhető maximális fókuszsíkbeli intenzitás ebben az esetben $3 \cdot 10^{13} \mathrm{~W} / \mathrm{cm}^{2}$ volt. Ily módon nem nyílt lehetőség a szürési elrendezés maximális energiatranszmisszió melletti vizsgálatára.

A 3-29. ábrán láthatóak a fókuszált intenzitás függvényében mért energia transzmisszió értékékek. A 3-28. ábrán látható elrendezéssel kapott pontok piros színnel vannak jelölve. Összehasonlításul a korábban mért elő-leképezés nélküli elrendezéssel felvett pontok is fel vannak tüntetve (fekete négyzetek). Látható, hogy az elő-leképezés alkalmazásával a korábban a $10^{-3}$ transzmissziós szinten túl is ugyanolyan meredekséggel csökken a 
transzmisszió értéke egészen addig, amíg el nem érjük az energiamérés tartományának alsó küszöbét. $\sim 4 \cdot 10^{12} \mathrm{~W} / \mathrm{cm}^{2}$ intenzitású lövések esetén a kimenő nyaláb energiája a detektor zajküszöbe alá esik. A mérés alapján azt mondhatjuk, hogy sikerült az ultraibolya tartományban az optikai leképezés kontrasztját $>10^{5}$ értékre javítani az és ezzel együtt a nemlineáris Fourier-szüréssel elérhető kontrasztjavítást is ezt megközelítő értékre kiterjeszteni.

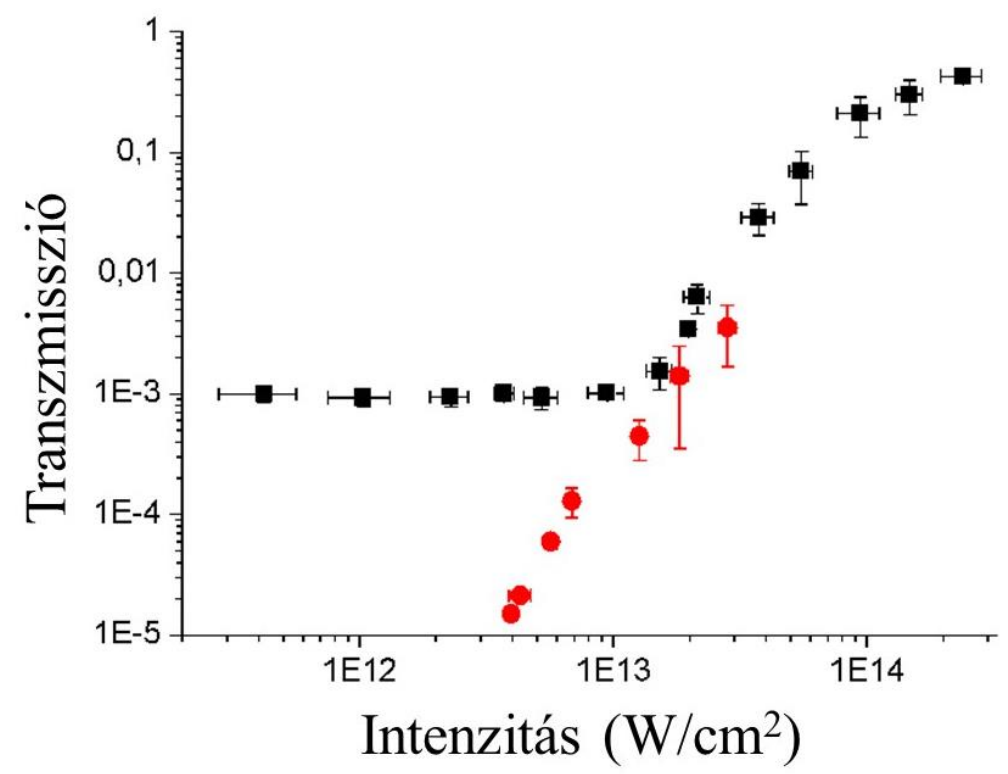

3-29. ábra

A kis nyilásszögü elö-leképezéssel kiegészitett nemlineáris Fourier-szürés intenzitástól függö transzmissziója (piros pontok) és az elö-leképezés nélküli transzmisszó (fekete négyzetek) [118].

\section{3.d. Diszkusszió}

Ebben a fejezetben bemutattam az optikai leképezés térbeli kontrasztjának javítására kapott kísérleti eredményeimet, amelyet a látható tartományban egy nagy dinamikus tartományú mérőrendszerrel mértem. A nagy térbeli kontraszttal leképezni kívánt gyűrü alakú tárgy térfrekvenciás eloszlását egy kis nyílásszöget - így korlátozott térbeli feloldást megengedő elö-leképezéssel moduláltam majd az így kapott kép $10^{-3}$ intenzitásszint alatti részeit egy újabb apertúrával takartam ki. Az így keletkező csökkentett térfrekvenciás komponensekkel bíró új tárgy leképezése során sikerült $10^{7}$-t meghaladó térbeli kontraszt értéket mérnem, és ezáltal a leképezés kontrasztját több mint 5 nagyságrenddel növeltem.

Kísérleti úton megvizsgáltam a nemlineáris Fourier-szüréssel elérhető kontrasztjavulást a nagyjelü és a kisjelü transzmisszió mérésével. Ehhez az elrendezés energia szerinti 
transzmisszióját mértem a fókuszsíkbeli intenzitás függvényében. Megvizsgáltam továbbá a szürésnek a nyaláb térbeli tulajdonságaira gyakorolt hatását. A kisjelü transzmisszió értékére a korábban a szakirodalomban leírt $10^{-3}$ limitet kaptam. Az optikai leképezés térbeli kontrasztja által okozott háttér csökkentésére a szürési elrendezést egy kis nyílásszögü elöleképezéssel egészítettem ki. Az így kiegészített elrendezés esetében a kisjelü transzmisszióra $10^{-5}$ értéket kaptam. A kapott értéket az energiamérő rendszernek a limitált dinamikus tartománya szabta meg. A $\sim 4 \cdot 10^{12} \mathrm{~W} / \mathrm{cm}^{2}$ intenzitás alatti impulzusok detektálására nem volt lehetőség.

Az elrendezéssel a megnövekedett számú optikai elemek miatt nem sikerült elérni a korábbi optimális - maximális transzmisszióhoz tartozó - intenzitást. A kis nyílásszögü elöleképezéssel kiegészített nemlineáris Fourier-szürés nagyintenzitású KrF lézerrendszerekbe való integrálása a megnövekedett energiaigény miatt nagyobb elő-erősítést vagy a szürési elrendezés erősítési átmenetek közti elosztását igényli. A fent leírt kísérleti eredmény alapján tehát kijelenthető, hogy a nemlineáris Fourier-szürés kontrasztjavítása meghaladja a plazma tükör és XPW technika kontrasztjavítását, így a technika további vizsgálata és alkalmazása nem csak az ultraibolya, de várhatóan a látható/infravörös tartományban is ígéretes. Ezt követő kutatásaim az elő-leképezéssel kiegészített szürési elrendezésnek egy nagyintenzitású KrF excimer lézerrendszerbe való integrálását célozták. 


\subsection{Nemlineáris Fourier-szürés nagyintenzitású excimer lézerrendszerbe való integrálása}

Az ultraibolya tartományban müködő rövid impulzusú excimer lézerek alkalmazása számos fény-anyag kölcsönhatási kísérletben perspektivikus. Az ilyen típusú lézerrendszerek egyik kedvező tulajdonsága, hogy az ultraibolya tartományban való erősítés előtti frekvenciakonverzió miatt az ultraibolya magimpulzus extrém nagy időbeli (és térbeli) tisztaságú. Ezen tulajdonság valamint a direkt erősítés miatt az időbeli háttér egyetlen forrása az erősített spontán emisszió. KrF erősítő közeg esetén a $10 \mathrm{~mJ}$ energiára való erősítés esetében az időbeli kontraszt értéke $10^{10}$ értékre korlátozódik. A 100 mJ-os tartományt elérve, azonban mindenképp szükséges egy a fókuszbeli intenzitáskontraszt növelésére irányuló technika alkalmazása, amivel ellensúlyozzuk a rövid hullámhosszból fakadó drasztikus ASE növekedést. Korábban az ilyen típusú rendszerekben [80] klasszikus térszűrést alkalmaztak, amely ugyan csökkenti az ASE energiáját, de a főimpulzussal együtt terjedő időbeli hátteret nem.

A korábbi fejezetekben bemutattam ultraibolya rövid impulzusok kontrasztjának javítására - plazma tükörrel illetve nemlineáris Fourier-szüréssel - kapott kísérleti eredményeimet. A plazma tükör technika alkalmazása a relatíve magas reflexiója miatt, az elő-leképezéssel kiegészített nemlineáris Fourier-szürés viszont extrém nagy kontrasztjavulása miatt előnyös. Mivel az energiaveszteség további erősítési átmenetekkel relatíve könnyen kompenzálható, ezért a nemlineáris Fourier-szürő lézerrendszerbe való integrálása mellett döntöttem. Ebben a fejezetben egy nagyintenzitású és nagy kontraszttal rendelkező $\mathrm{KrF}$ lézerrendszer fejlesztésével kapcsolatos kísérleti eredményeimet ismertetem [120].

\section{4.a. Nemlineáris Fourier-szűrés erősítési átmenetek közé integrálása}

Az előző fejezetben bemutattam, hogy a kis nyílásszögű elő-leképezéssel kiegészített nemlineáris Fourier-szürés kontrasztjavítása megközelíti (az intenzitás függvényében mért transzmisszió görbe meredeksége alapján várhatóan meg is haladja) a $10^{5}$ értéket. A kísérlet tanulsága szerint ugyanakkor az optikai elemek megnövekedett száma miatt az elrendezés energiaigénye is megnőtt. A probléma egyik lehetséges megoldása lehet, ha - a 3-30. ábrán látható módon - a kétszeri leképezés párhuzamos nyalábmenetű részeibe foglaljuk a $\mathrm{KrF}$ erősítési átmeneteit. Ezáltal az elő-leképezés okozta energiaveszteséget kompenzálja a közeg erösítése. 


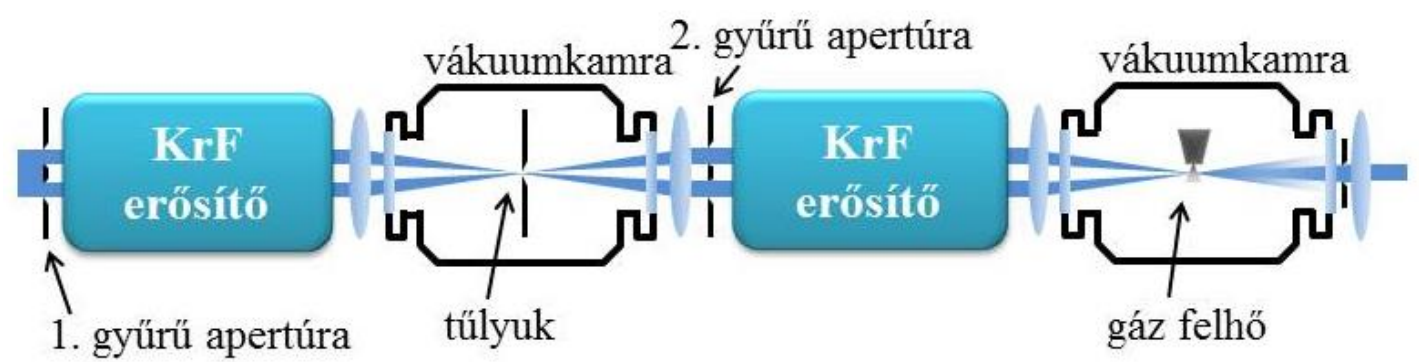

3-30. ábra

A kis nyilásszögü elö-leképezéssel kiegészitett nemlineáris Fourier-szürés sémája KrF erösitési átmenetekkel kiegészitve.

Az előkísérletek alapján a szürés megfelelő energiahatásfokkal történő müködéséhez $10^{14} \mathrm{~W} / \mathrm{cm}^{2}$ fókuszsíkbeli csúcsintenzitás elérése szükséges. A szürés stabil müködéséhez azonban a fókuszsíkbeli eloszlás térbeli regularitása és lövésenkénti stabilitása is fontos. Ugyanakkor a nyalábméret növelésével a fázisfront torzulások miatt ez egyre nehezebben teljesíthető. A nyaláb által elszenvedett fázisfront torzulás a megtett úttal és a nyalábátmérő négyzetével skálázódik. A 100 mJ-os energiatartomány elérése az energiasürüségre vonatkozó megkötés [77, 80] miatt csak $4 \times 4 \mathrm{~cm}^{2}$-es nyalábméret mellett illetve két résznyalábos optikai multiplexelés mellett lehetséges. A szürés után és a végerősítő fokozat között mindenképp szükséges egy köztes erősítő fokozat, ami a szürés eredményeképp előálló nagy kontrasztú impulzus energiáját a multiplexeléssel kiegészített végerősítő által megkívánt >10 mJ-os szintre erősíti. (Kisebb bemenő energiák esetén az energiakinyerés hatásfoka jelentősen romlik.)

Ezen megfontolások alapján egy olyan erősítőláncot építettem meg, ami 2 db előerősítő és egy végerősítő fokozatból áll és minden egyes excimer erősítő két átmenetes elrendezésben van használva (a végerősítő fokozat esetén multiplexeléssel kiegészítve). A nemlineáris Fourier-szürést a két előerősítő közé integráltam, olyan módon, hogy a kis nyílásszögü előleképezéshez szükséges elrendezés az első erősítő második erősítési átmenete elött foglal helyet, de a szürés alapját képező nemlineáris kölcsönhatás a második erősítési átmenet után történik. Így a (nemlineáris szürés bemenetét képező) korlátozott térfrekvenciás tárgy előállítása közben erősítéssel kompenzáljuk az optikai elemek okozta energiaveszteséget. Ezzel az elrendezéssel elérhetővé válik a nemlineáris kölcsönhatáshoz szükséges intenzitás továbbá a szürési elrendezés stabil müködése is biztosított. A stabilitást tovább segíti, hogy a rendszer ezen pontján a nyalábméret nem sokkal haladja meg a $2 \mathrm{~cm}-\mathrm{t}$. A kisebb nyalábméret jobb fókuszálhatóságot biztosít. 
Egy másik lehetséges elrendezés, ha a nemlineáris szürés a második előerősítő két erősítési átmenete közé kerül integrálásra. Ennek potenciális előnye, hogy a szürés után kisebb lehetőséget (kevesebb erősítési átmenetet) engedünk az ASE kifejlődésének, mivel a nagyobb bemenő energia miatt a szürést követő erösítési igény is kisebb. Erre való tekintettel a nemlineáris Fourier-szürő nagyobb energiájú impulzusokra való alkalmazása mindenképp célszerü a későbbiekben. Ennek a megoldásnak a mellőzése elsősorban praktikus okokkal magyarázható; a $\mathrm{KrF}$ excimerek rövid erősítési időablakába valamint az előkísérletek paramétereibe való beilleszthetőség következménye.

A fent részletezett szempontok miatt a 3-31. ábrán látható módon alakítottam át a HILL laboratórium egyik festék/excimer lézerrendszerét a nemlineáris Fourier-szürő integrálása céljából. A korábban bemutatott rendszerekhez hasonlóan a szub-pikoszekundumos impulzus generálása egy $\mathrm{XeCl}$ excimer lézer által pumpált festéklézerrendszerrel történik. Ennek központi eleme egy elosztott visszacsatolású festéklézer (DFDL) ami néhány száz femtoszekundumos impulzusokat generál $497 \mathrm{~nm}$ központi hullámhosszon. Az ezt megelőző kaszkád festéklézer lánc a DFDL-t pumpáló 5-10 ps hosszúságú impulzusok előállítását végzi. A frekvencia kétszerezés előtt a 497 nm központi hullámhosszúságú magimpulzusok energiáját $200 \mu \mathrm{J}$-os szintre erősítjük. Rövid impulzusok frekvenciakétszerezése esetén problémát okoz, hogy a hagyományos fázisillesztési elrendezésben a kristályban fellépő diszperzió miatt a fázisillesztés nem teljesíthető minden hullámhossz komponensre tetszőleges L kristályhosszra. Ennek következtében a sávszélességgel fordítottan arányosan változik az alkalmazható kristály hossza, azaz rövid impulzusok esetén csak vékony kristályt lehet használni. Mivel a kétszerezés hatásfoka $\mathrm{L}^{2}$-el arányos és ezt az intenzitásnövelésével (a kristályban fellépő nemlinearitások miatt) nem lehet kompenzálni, ennek következtében az impulzusok energiája a kétszerezés után 15-20 $\mu \mathrm{J}$-ra csökken. Ugyanakkor az ott alkalmazott aktív térszürésnek köszönhetően a nyaláb tér- és időbeli tulajdonságai közel ideálisak, így a lézerrendszer kimenetén mérhető tér- és időbeli kontrasztot gyakorlatilag egyedül az ultraibolya tartományban való erősítés szabja meg. 


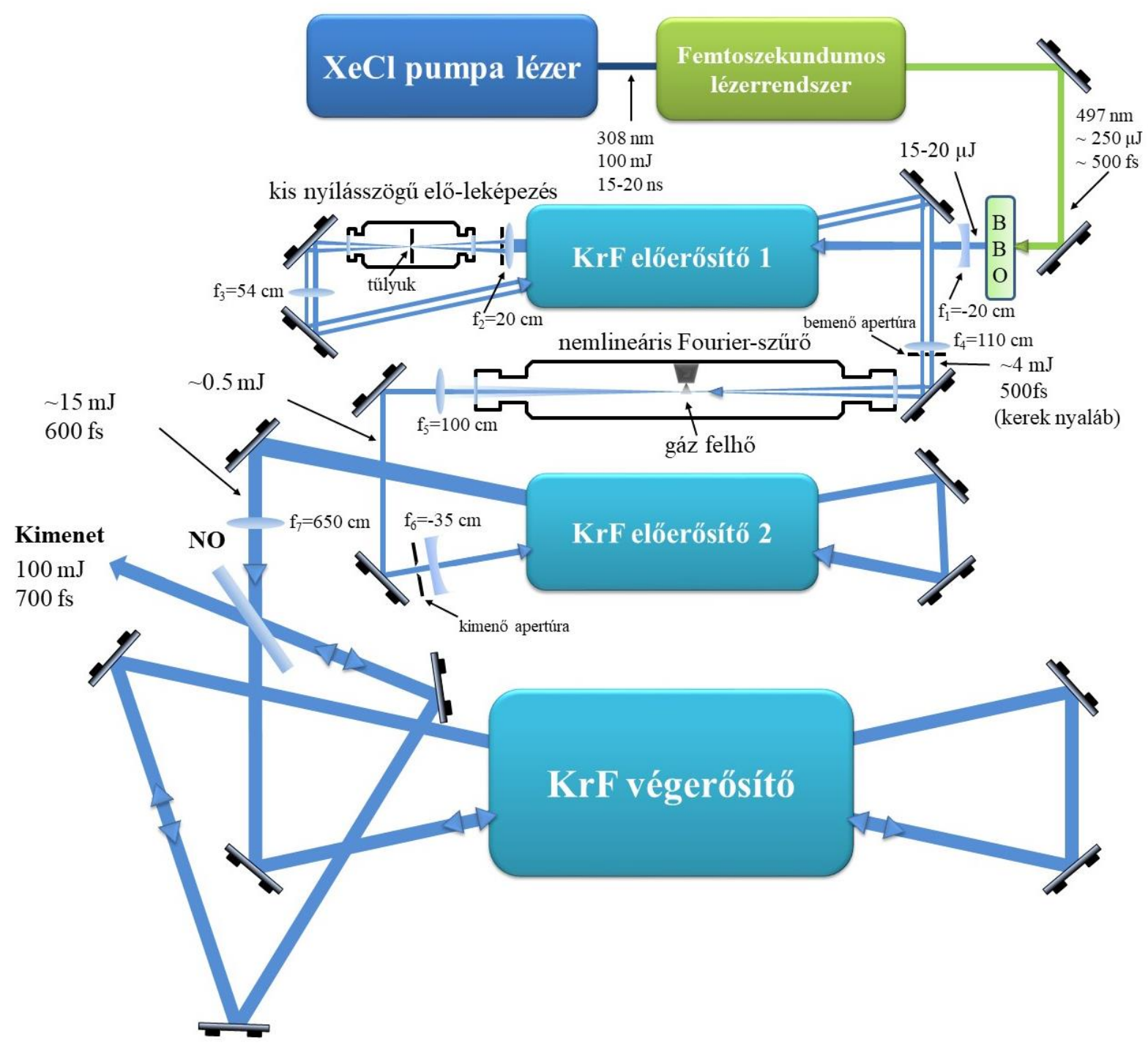

3-31. ábra

A nagy kontrasztú, nagyintenzitású KrF excimer lézer sematikus elrendezése. (BBO: frekvenciakétszerezö $\beta$-bárium borát kristály, NO: nyalábosztó).

Az ultraibolya magimpulzus erősítése során több tényezőt is figyelembe kell venni. Az erősítés optimumát az energiakinyerés hatásfoka és az energiakontraszt határozza meg, amiket a telítődő erősítés és a nem telítődő abszorpció jelensége együttesen befolyásol. KrF közeg esetén az alapállapotú $\mathrm{F}_{2}$ valamint a $\mathrm{Kr}_{2}{ }^{+}, \mathrm{F}^{-}$ionok és a kétszeresen gerjesztett $\mathrm{Kr}^{* *}$ atomok okozzák az abszorpciót. Ahogy a 2.2. pontban bemutattam az optimális erősítési tartomány a telítési energia sűrüség 1,1 - 2,2-szeres értékei közé esik. Ezen feltétel teljesítése az erősítés során csak növekvő keresztmetszet mellett lehetséges. Ennek megfelelően a rendszerben használt $\mathrm{KrF}$ excimer erősítőknek a keresztmetszetét egyik irányba meghatározó elektródatávok rendre 2,1; 2,5 és 3,8 cm voltak. A keresztmetszet növelésének további módja az erősítők döntött tengely mentén való használata. 
Ennek megfelelően a frekvenciakétszerezés után egy $\mathrm{f}_{1}=-20 \mathrm{~cm}$-es lencse segítségével széttartóvá tett nyaláb az első erősítési átmenetet a cső szimmetria tengelyéhez képest $1,4^{\circ}$-os szögben teszi meg. Az $\sim 1 \mathrm{~mJ}$ energia szintre erősített nyalábot egy $\mathrm{f}_{2}=20 \mathrm{~cm}$-es fókuszhosszú lencse fókuszálja át egy vákuumtérbe helyezett tűlyukon. Közvetlen a fókuszáló lencse után található az első gyürü alakú apertúra. Ezt a gyürüt a vákuumcső után egy $\mathrm{f}_{3}=54 \mathrm{~cm}$-es lencse képezi le úgy, hogy a közel párhuzamos nyalábmenet közben történik a második erösítési átmenet $1,9^{\circ}$-os szög alatt. A második erösítési átmenet után (a leképezés képsíkjában) van elhelyezve a második gyürü alakú apertúra. Az így kialakított gyürü alakú nyaláb energiája 4 mJ. Közvetlen az apertúra előtt egy $\mathrm{f}_{4}=110 \mathrm{~cm}$-es fókuszú lencse fókuszálja a gázfelhőbe a gyürű alakú nyalábot. A kísérleti elrendezésben az elő-leképezéshez szükséges tülyuk és a nemlineáris kölcsönhatáshoz szükséges gázfelhő vákuumterét ugyanazon elővákuum szivattyú szívta. Az impulzusüzemü gázszelepet tartalmazó vákuumtér után egy $\mathrm{f}_{5}=100 \mathrm{~cm}$-es fókuszú lencse képezi le a második gyürü alakú apertúrát a második KrF előerősítő elé. Ebben a képsíkban egy írisz van elhelyezve, amely csak az eredeti gyürü alakú nyaláb középső részét engedi át. Látható, hogy a 3-30. ábrán látható elrendezéshez képest annyiban módosítottam a szürés erősítési átmenetek közé való integrálását, hogy egy adott leképezés során először a fókuszálás történik meg és a leképező lencse után történik az erősítés a közel párhuzamos nyalábbal.

A kísérlet során nehézséget jelentett, hogy ezen első KrF előerősítő cső relatíve keskeny elektromos kisüléssel rendelkezett és a kisülés homogenitása nem volt ideális. Ez a körülmény a nemlineáris Fourier-szürő bemenetként szolgáló (modulált térfrekvenciás spektrumú) gyürủ alakú nyalábban is tendenciózus inhomogenitást és nagyobb energiaszórást okozott $(\sim 10 \%)$. A szürés szempontjából ugyanakkor a legfontosabb paraméter a nyaláb Fourier-síkbeli eloszlása, melynek vizsgálatához a gázfelhő közepén lévő síkot egy f=8,5 cmes gyüjtőlencse segítségével N=26-szoros nagyítással képeztem le egy Hamamatsu C7040 típusú CCD kamerára. A mérések tanulsága szerint a fókuszsíkbeli eloszlás alakja stabil, de a korábban tapasztalt tengelyszimmetria helyett tükörszimmetria jellemzi. Egy tipikus eloszlást a 3-32. ábra mutat. Látható, hogy a középső maximumon kívüli első mellékmaximum - a várt körszimmetrikus eloszlás helyett - 4 pontba koncentrálódik. Ennek oka, hogy az elektromos kisüléssel pumpált excimer lézerek a függőleges irányban homogénebb és élesebben határolt nyalábprofilt eredményeznek. Mivel a gyürü alakú nyaláb kialakításánál a lehető legnagyobb nyaláb méretet (és ezzel energiát) kívántam elérni, ezért a gyürű alakú nyaláb is „megörökölte” az excimerekre jellemző - a kisülés geometriájából adódó - tükörszimmetrikus 
eloszlást, valamint a gyürü nem homogén módon volt kivilágítva (a szélek intenzitása kisebb volt, mint a belsőbb pontoké).

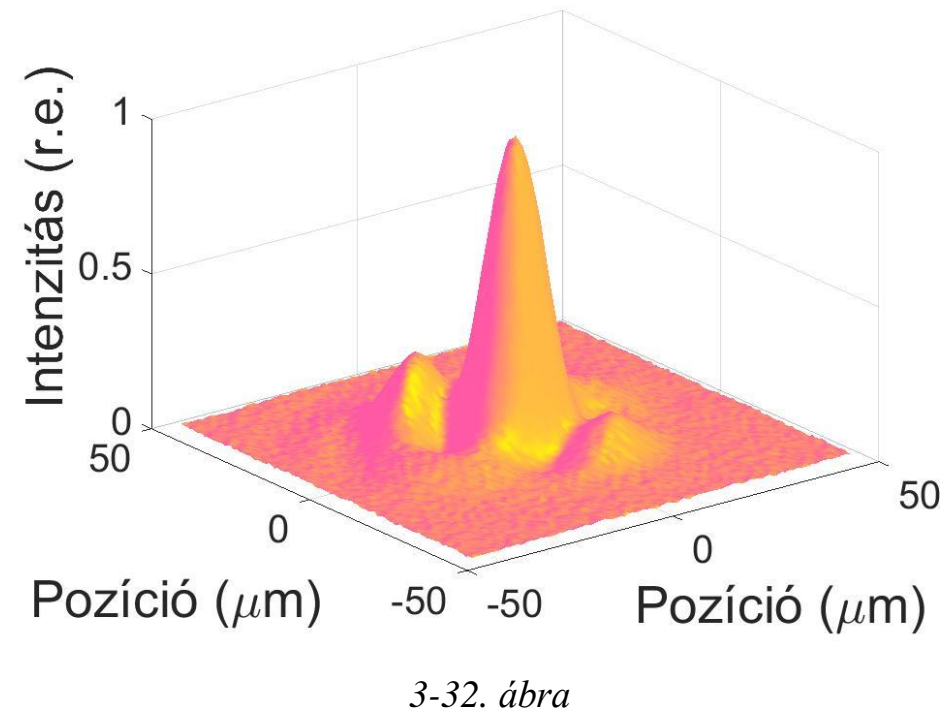

Az elsö erösitö utáni gyürü alakú nyaláb fókuszsikkbeli eloszlása f/65-ös fókuszálás mellett [120].

Egyszerű numerikus szimulációval belátható, hogy az excimerekre jellemző nyalábprofilból kivágott gyürü alakú nyaláb a kísérletileg kapott, a 3-32. ábrán látható eloszlást eredményezi a fókuszsíkban. A 3-33a. ábrán látható egy általam - hatod rendü polinomfüggvény segítségével - szimulált excimer erősítők kimenetére jellemző nyalábeloszlás. Az ebből kivágott gyürü alakú nyaláb intenzitását a gyürü külső határainál a maximális (belső sugár határán lévő) érték 10\%-ára választottam számolásaimban. Ezen gyürü alakú nyaláb Fourier-síkbeli eloszlása a 3-33b. ábrán látható. Megfigyelhető, hogy a 3-32. ábrához hasonlóan a mellékrendek egyre inkább tükörszimmetriát mutatnak. Ugyanakkor egy ilyen eloszlású bemenő nyaláb esetén a nemlineáris Fourier-szürés kimenete a korábbiakhoz hasonló, optimális kimeneti eloszlást ad (3-34. ábra). A szimuláció eredményére alapozva kimondható, hogy önmagában az excimer erősítő közeg okozta tükörszimmetrikus eloszlás nem befolyásolja jelentősen a nemlineáris Fourier-szürő müködését. 

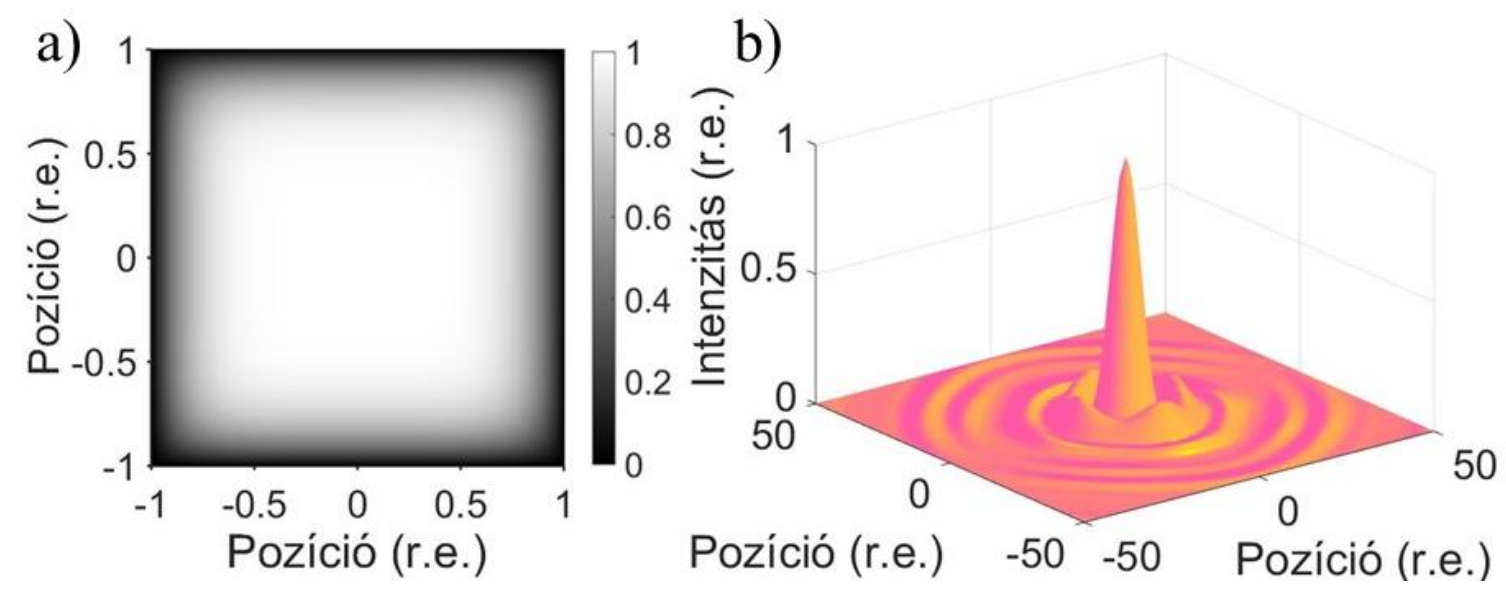

3-33. ábra

Transzverzális gerjesztésü excimer erösitök kimenö nyalábjának numerikus modellje (a) és egy ebböl kivágott gyürü alakú nyaláb Fourier-sikbeli eloszlásának (b).

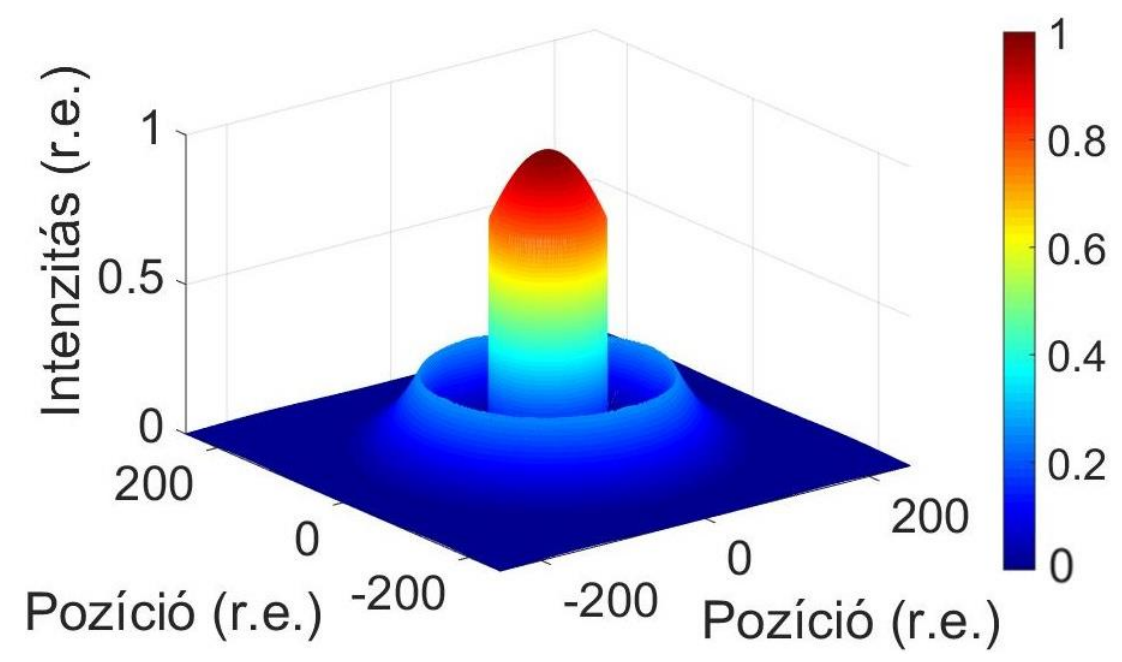

3-34. ábra

Az előbbi (3-33.) ábrának megfelelö térbeli eloszlású nyaláb nemlineáris-Fourier-szürö utáni eloszlása.

A nemlineáris szürés müködése szempontjából zavaró hatás volt, hogy az első előerôsítő nem optimális müködése féloldalas nyalábeloszlást okozott, amely lövésenként is ingadozott. Ezt a hatást sajnos nem sikerült kiküszöbölnöm, így ez negatívan befolyásolta a nemlineáris szűrő energia transzmisszióját és stabilitását. A folyamat belső energia hatásfokát 20\%-nak mértem. Ez, valamint a vákuumkamra ablakai, a fókuszáló és leképező lencsék továbbá a tükrök által okozott veszteségnek együttesen >0.5 mJ energiájú nyalábot eredményezett a második előerősítő előtt. A folyamat nemlinearitása a relatíve nagy értékü bemenő szórással együtt $20 \%$-os kimenő energiaszórást okozott, amit azonban a követő erősítők telítésben való működésével nagymértékben sikerült csökkenteni. 


\section{4.b. Nagy kontrasztú impulzusok erősítése}

Ahogy a 3-31. ábrán látható, a második előerősítő előtt a nyalábot egy $\mathrm{f}_{6}=-35 \mathrm{~cm}-\mathrm{es}$ lencsével tágulóvá tettem úgy, hogy a második erösítési átmenet végére az éppen kitöltse a 2,5 cm-es elektródatávot. A legkedvezőbb energiakontraszt elérését szem előtt tartva az aktuális nyalábméret és az erősítő cső ablaka által megszabott legnagyobb szögre állítottam az erősítési átmeneteket $\left(3,1^{\circ}\right.$ ill. $\left.2 \cdot 9^{\circ}\right)$. A második előerősítő után $15-20 \mathrm{~mJ}$ volt a nyaláb energiája és $10 \%$ alatti volt a szórása. Ezen a ponton az ASE energiája a föimpulzus energiájának 2\%-át érte el. A második előerősítő után - mikor a nyaláb mérete elérte a végerősítő által megszabott maximális $3,8 \mathrm{~cm}$-es értéket - egy $\mathrm{f}_{7}=650 \mathrm{~cm}$-es lencsével párhuzamosítottam a nyalábot.

A végerősítő fokozat (a 3-32. ábrán látható módon) egy két rész-nyalábos interferometrikus multiplexelési elrendezésben volt használva. A nyaláb osztását (és újraegyesítését) egy Brewster-szögben használt, kvarc hordozóra felvitt dielektrikum (polarizációs osztó) vékonyréteg biztosította, amely a p-polarizációjú nyalábrészt áteresztette, az s-polarizációjú nyalábrészt pedig reflektálta. Lineáris polarizációjú beeső nyaláb esetén az ideális osztáshoz $45^{\circ}$-os rezgési irány tartozik (a beesési síkhoz viszonyítva). A polarizációs osztóra beeső nyaláb polarizációját egy a frekvenciakétszerezés után elhelyezett ALPHALAS gyártmányú $2,5 \mathrm{~mm}$ vastag $\lambda / 2$-es lemezzel lehetett változtatni. A résznyalábok 2 átmenetes döntött tengelyü erősítés során erösödtek a végerősítő paraméterei által megszabott legnagyobb $2,4^{\circ}$-os szögben. A két résznyaláb között, ill. egy résznyaláb két erősítési átmenete között a késleltetések úgy vannak megválasztva, hogy időben rendre a $\mathrm{p}$ ág első átmenete, az s-ág első átmenete, a p-ág második átmenete és végül az s-ág második átmenete halad át az erősítőn. A résznyalábok a körbejárás után az elrendezés által biztosított interferometrikus pontossággal egyesülnek újból a kimeneten.

Mivel a KrF excimerek erősítési időablakát a rövid relaxációs idők miatt elsősorban a pumpálás ideje szabja meg (esetünkben $\sim 15 \mathrm{~ns}$ ), ezért az erősítők hosszát és a két átmenetes erősítéseket figyelembe véve kiemelten fontos a $\mathrm{XeCl}$ pumpáló lézer és az erősítő modulok ns-os pontosságú szinkronizációja. A két előerősítő cső közös elektromos körről van meghajtva, így pontos és időben állandó szinkronizációjuk biztosított. $\mathrm{A} \mathrm{XeCl}$ pumpalézer, a KrF előerősítő egység és a $\mathrm{KrF}$ végerősítő működésének szinkronizálását, egy a Kísérleti Fizikai Tanszéken tervezett és kivitelezett aktív visszacsatolással müködő szinkronizáló 
egység végezte. Ez a készülék a nagyobb időállandójú szinkronbeli elcsúszásokat képes kompenzálni.

\section{4.c. A nagy időbeli kontraszttal rendelkező nagyintenzitású excimer lézerrendszer impulzusainak karakterizálása.}

A rendszer kimenetén a rövid impulzus és az ASE energiáját egy GENTEC QE50PL-SMD-D0 típusú mérőfejjel mértem. Az ASE energiáját a kimeneten egyszerüen a rövid jel első előerősítő előtti kitakarásával állapítottam meg. A rövid impulzus energiáját egyszerüen a teljes energia és az ASE energia különbségével definiáltam. (Megjegyzem, hogy az ASE energiamérésére ez egy felső becslés, ugyanis a rövid impulzus jelenléte telítés esetén jelentősen csökkentheti az ASE számára hozzáférhető energiát.) A rövid impulzus 200 lövésből átlagolt energiája (az ASE energiájának levonásával) meghaladta a 100 mJ-os értéket 4\%-os energiaszórás mellett. Az energiaszórás csökkenése a rövid impulzus erősítésekor fellépő telítődés kedvező hatása. A kimeneten a mérés tanulsága szerint az ASE részaránya elérte a 10\%-ot. Az erősítés telítődése az energia szórás szempontjából ugyan kedvező hatás, de az energia kontraszt drasztikus romlását is okozhatja. A telítődés mértékének vizsgálatára a második előerősítő két erősítési átmenete között változtatható mértékủ gyengítést vezettem be egy $\mathrm{CaF}_{2}$ hordozóra párologtatott dielektrikum attenuátor segítségével. Ilyen módon változtatva a nemlineáris Fourier-szürés után alkalmazott erősítés mértékét azt tapasztaltam, hogy a kimenő energia felére $(50 \mathrm{~mJ})$ csökkenése esetén az ASE részaránya a tizedére esik, ami 1\%-os energia kontrasztot jelent. A nemlineáris Fourier-szürés utáni erősítés csökkentésével tehát nagyságrendekkel jobb kontrasztot lehet elérni a kimenő energia (lényegesen kisebb mértékű) csökkentése árán.

A nemlineáris Fourier-szürőt magában foglaló rendszer legfontosabb paramétere a kimenő impulzusok fókuszsíkbeli intenzitáskontrasztja. Mivel a rövid impulzusú $\mathrm{KrF}$ lézerrendszerekben nem használnak fázismodulált erősítési sémát, ezért az időbeli háttér egyetlen forrása az erősített spontán emisszió. Az ASE keletkezése okán (nagyságrendi értelemben) időben és térben is egyenletes és reguláris eloszlású, intenzitása ezért egyszerü eszközökkel is mérhető. Ennél fogva az intenzitáskontraszt mérésére megalapozott és kísérletileg pontos eredményt adó módszer, ha az ASE energiáját, térszögét (fókuszálhatóságát) és időbeli hosszát a rövid impulzus ezen jellemzőivel összevetjük. Az így képzett arányok szorzata adja a fókuszsíkbeli kontraszt értékét. Természetesen az időbeli kontraszt mérésének legmegbízhatóbb eszköze egy harmad- (vagy magasabb) rendü 
autokorrelátor alkalmazása lenne, aminek a dinamikus tartománya meghaladja a mérni kívánt kontrasztértéket. Ultraibolya rövid impulzusok időbeli karakterizálására korábban bevezettek másodrendü autokorrelátoron [68] és frekvencia-bontott optikai kapuzáson (FROG) [121] alapuló mérési technikát is. Sajnos ezen módszerek dinamikus tartománya nem közelíti meg az esetünkben elérni kívánt értéket. Ismereteim szerint a dolgozat megírásának időpontjában nincs olyan technika, amely lehetővé tenné ultraibolya impulzusok kontrasztjának ilyen tartományon való direkt mérését.

Fentebb ismertettem a rövid jel és az ASE energiahányadosát a rendszer kimenetén a nemlineáris szürés után alkalmazott erősítés függvényében. $100 \mathrm{~mJ}$ maximális kimenő energia mellett 10\%-nak, 50 mJ kimenő energia mellett 1\%-nak mértem. Fontosnak tartom megjegyezni, hogy az ASE energia mérése során nem okozott detektálható változást az, ha a nemlineáris szürés után, a második előerősítő előtt kitakartam a nyalábot. Ez a megfigyelés azt jelenti, hogy az ASE energiájának egésze (a mérés határain belül) a nemlineáris Fourierszürő után keletkezik. Ezután az ASE és a rövid jel fókuszálhatóságát hasonlítottam össze, először a második előerősítő után, majd a kimeneten.

A második előerősítő cső ablakán kilépő táguló nyaláb kör alakú és 2,5 cm átmérőjü. A dielektrikum tükörrel kicsatolt nyaláb távoli zónabeli vizsgálatát egy f/150-es fókuszálást biztosító gyűjtőlencse segítségével valósítottam meg. A rövid jel fókuszsíkbeli eloszlását a korábban is használt Hamamatsu C7040 típusú CCD kamerával vizsgáltam. A relatíve nagy fszám miatt nem alkalmaztam további nagyítást a fókuszfolt leképezésére. A CCD kamera telítését elkerülendő a fókuszáló lencse előtt kvarc hordozójú dielektrikum tükörrel és szürkeszürők segítségével gyengítettem a nyalábot. Érdemesnek tartom megjegyezni, hogy a vékony kvarc hordozójú szürkeszürők jelentősen ronthatják a nyaláb minőségét, ezáltal a mérés a valódinál rosszabb fókuszeloszlást is mutathat. Az ezen elrendezéssel kapott eloszlások egy tipikus felvételét láthatjuk 3D-s ábrázolásban a 3-35. ábrán. Az x és y tengely menti metszeteket is feltüntettem (piros görbék) valamint összehasonlításképpen az elmélet által jósolt diffrakció-limitált eloszlást is (fekete görbék). A nyaláb fókuszfolt átmérője 1,5szer nagyobb a diffrakció-limithez képest. Az ASE-nek a rövid jel fókuszsíkjában mérhető térbeli méretét - annak nagysága okán - fotópapírral határoztam meg. Azt találtam, hogy az ASE a rövid jelhez képest $>3 \cdot 10^{5}$-szer nagyobb térszögben terjed. 


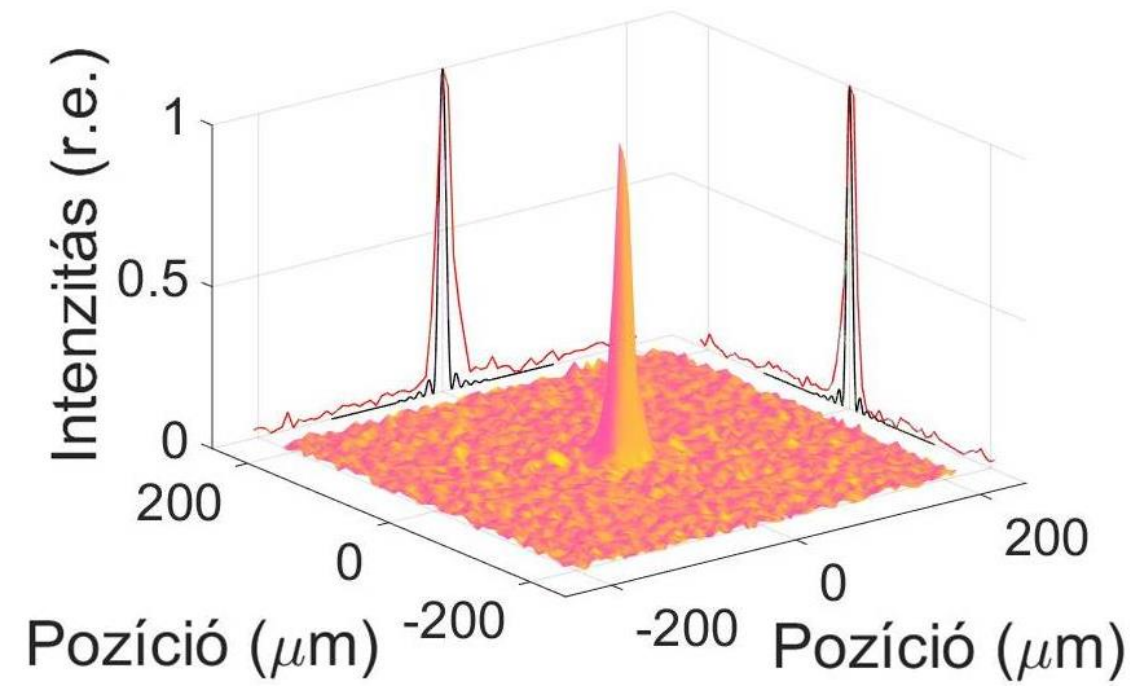

3-35. ábra

A nyaláb fókuszsíkbeli intenzitáseloszlása a második elöerösitő után f/150-es fókuszálás esetén. A kép szélein az eloszlás metszetei (piros görbék) illetve összehasonlitás céljából az ideális diffrakció-limitált profil (fekete görbék) láthatóak [120].

A rendszer kimenetén a végerősítő után is hasonló elrendezésben mértem a rövid jel és az ASE térszögét. A nyaláb alakja a végerősítő után az aktív közeg geometriájának következtében inkább négyzet alakú $\sim 38$ x 38 mm-es. Egy gyüjtőlencse segítségével f/30-as fókuszálást alkalmaztam. A fókuszsíkbeli eloszlást egy f=5 cm-es gyüjtőlencse segítségével $\mathrm{N}=11$-szeres nagyítás mellett képeztem a CCD kamerára. Egy tipikus eloszlást 3D-s ábrázolásban a 3-36. ábra szemléltet. Ez esetben is feltüntettem az x és y tengely menti metszeteket (piros görbék) valamint összehasonlítás céljából az elmélet által jósolt diffrakciólimitált eloszlást is (fekete görbék). A nyaláb fókuszfolt átmérője 2-szer nagyobb a diffrakciólimithez képest. Az ASE fókuszsíkbeli méretét itt is fotópapír segítségével állapítottam meg és azt találtam, hogy ez esetben $~ 3 \cdot 10^{5}$-szer nagyobb térszögben terjed az ASE. Fontosnak tartom megjegyezni, hogy - a korábbi megfigyelésekhez hasonlóan - a rendszer végén és a második előerősítő után is az ASE térbeli eloszlásán semmilyen változást nem tapasztaltam akkor, ha a nemlineáris szürő után kitakarom a nyalábot. Azaz a mérés határain belül a rendszer végén mérhető ASE térbeli eloszlását teljes egészében a nemlineáris Fourier-szürés után keletkező ASE határozza meg. 


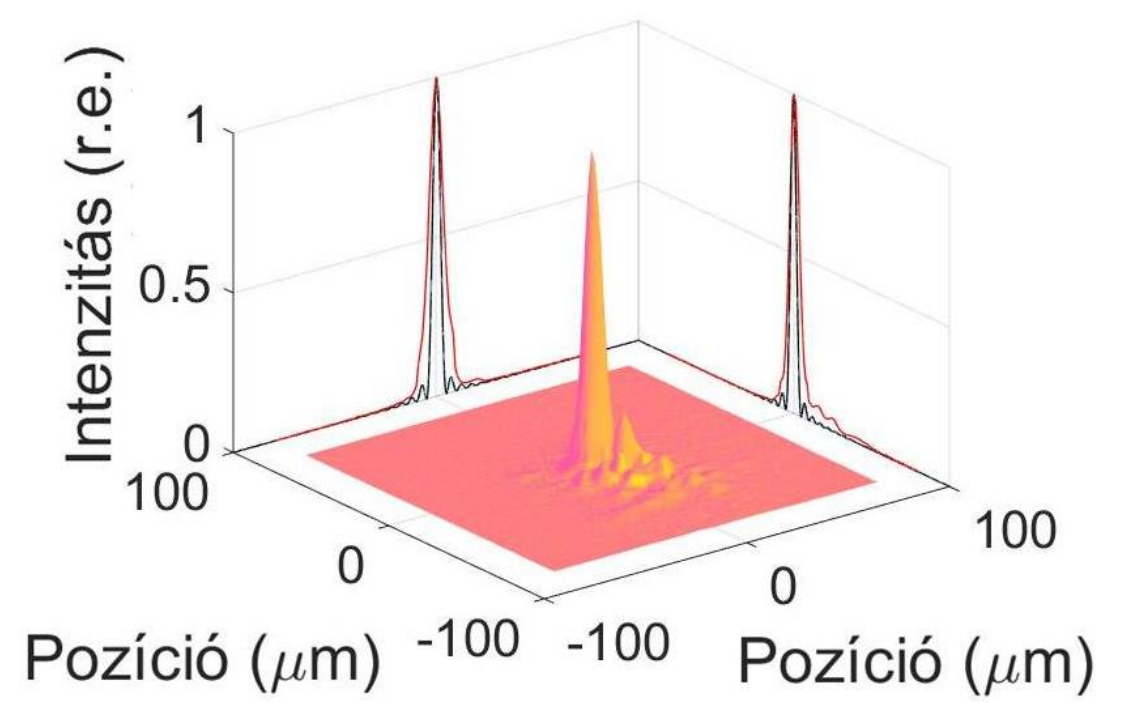

3-36. ábra

A rendszer kimenetén mért nyaláb fókuszeloszlása f/30-as fókuszálás esetén. A kép szélein az eloszlás metszetei (piros görbék) és összehasonlitásul az ideális diffrakció-limitált profil (fekete görbék) láthatóak [120].

A nyaláb közeli zónabeli eloszlását is a fent vázolt elrendezéssel vizsgáltam meg, úgy, hogy a CCD kamerát a fókuszáló lencse utáni szükülö nyalábba helyeztem. A CCD kamerát addig távolítottam a lencsétől, amíg a nyaláb éppen kitöltötte a kamera fényérzékeny felületét. Az így rögzített nyalábeloszlás és annak x és y irányú metszete a 3-37. ábrán látható. Megjegyzem, hogy a nyalábeloszlás ilyen módszerrel való felvétele nem adja korrektül vissza a rendszerből kilépő nyaláb térbeli eloszlását, hiszen a közben megtett út és a szükülő nyalábméret már egy Fresnel-elhajlással terhelt nyalábeloszlást eredményez. A 3-37. ábrán látható eloszlás a kilépő nyaláb $\mathrm{N}_{\mathrm{F}}=300$ Fresnel-számmal jellemezhető elhajlási képének felel meg, ennek következtében az inhomogenitások kiemelten láthatók. (A Fresnel-számot egy apertúrán áthaladó hullám esetén az átmérő négyzetének és a hullámhossz illetve, a megtett út szorzatának a hányadosa definiálja.) 


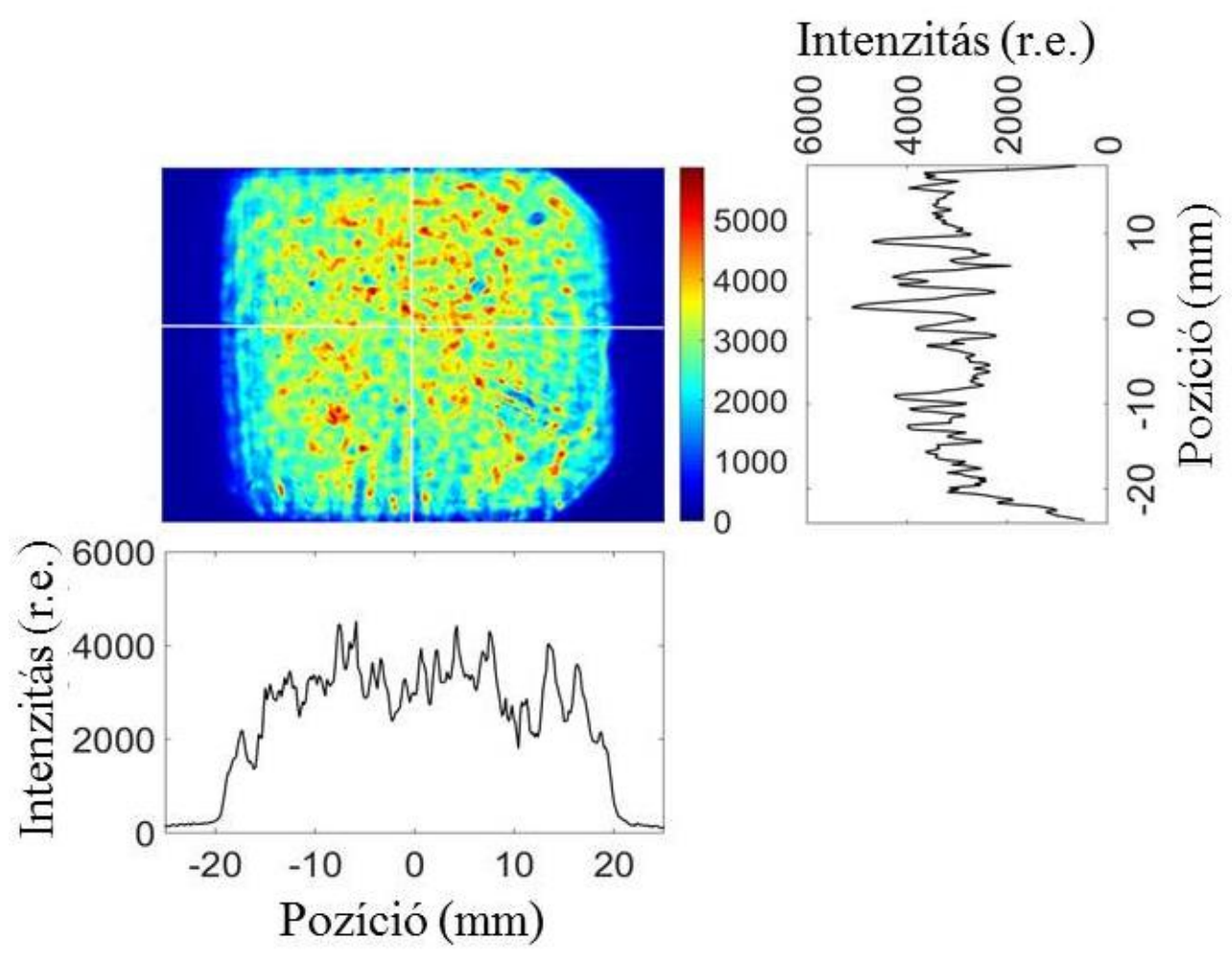

3-37. ábra

A kimenö nyaláb közeli zónabeli térbeli intenzitáseloszlása (az elhajlásra jellemzö

Fresnel-szám értéke 300) [120].

Az intenzitáskontraszt meghatározásához a rövid impulzus és az ASE időbeli alakját is szükséges mérni. A rövid impulzus időbeli hosszát a 3.1 pontban leírthoz hasonlóan egy másodrendủ autokorrelátorral mértem [68]. A detektor által megszabott dinamikus tartomány sajnos nem nyújt lehetőséget az impulzustalp alakjának méréséhez, azonban a félértékszélesség könnyedén meghatározható. A rövid impulzus időbeli hosszát a rendszer több pontján is megmértem. A 3-38a. ábrán látható az első előerősítő után mért másodrendü autokorrelációs görbe ami 500 fs félrétékü impulzushossznak felel meg. Ez az impulzusidő megegyezik a korábban bemutatott rövid impulzusú $\mathrm{KrF}$ festék-excimer lézerrendszerek esetében mért értékekkel. A 3-38b. ábrán a második előerősítő után mért - 600 fs-os impulzushossznak megfelelő - autokorrelációs görbe látható. A rendszer kimenetén mérhető impulzusok autokorrelációs görbéjét a 3-39. ábra mutatja, ami 700 fs-os impulzushossznak felel meg. 

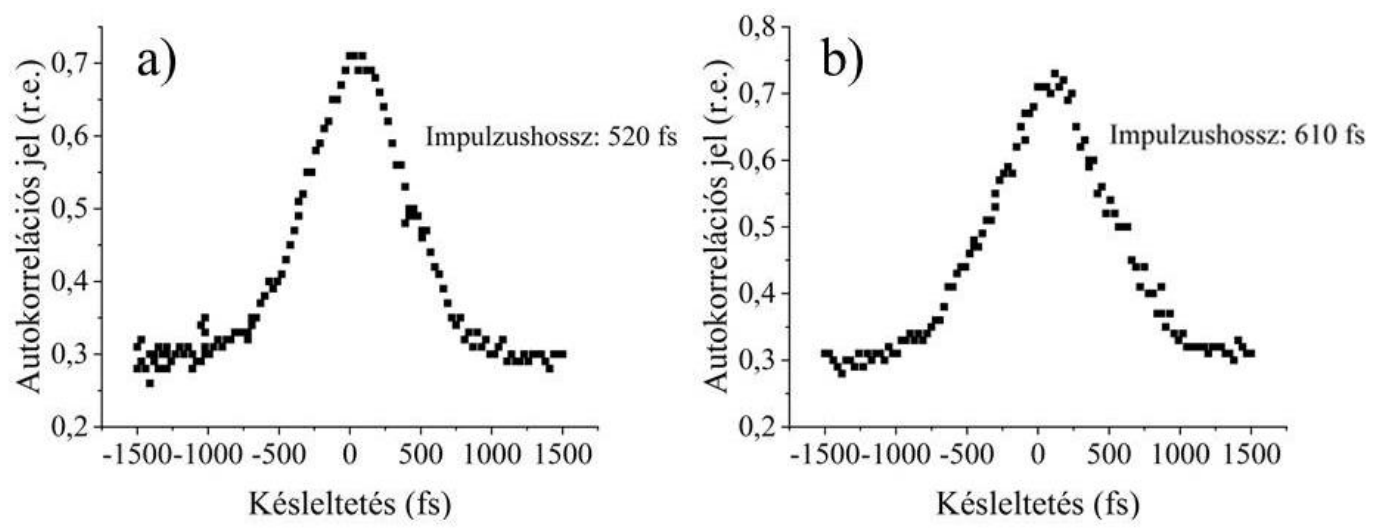

3-38. ábra

Az elsö elöerösitö (a) és a második elöerösitő (b) után mért impulzusok másodrendü autokorrelációs görbéje. A görbék félértékszélessége rendre 520 és 610 fs impulzushossznak felel meg.

Az ASE időbeli alakját egy THORLABS DET 210 típusú fotodiódával és egy GwINSTEK GDS-3504 típusú 500 MHz-es oszcilloszkóp segítségével mértem. Az ASE időbeli alakja egyenletes gauss-görbe eloszlású és időbeli szélessége 15-20 ns, azaz 3·10 szer hosszabb, mint a rövid impulzusé. Fontosnak tartom megjegyezni, hogy - a korábbi megfigyelésemmel összhangban - az ASE időbeli mérése során nem tapasztalatam a nemlineáris Fourier-szürő előttről származó időbeli háttér megjelenését.

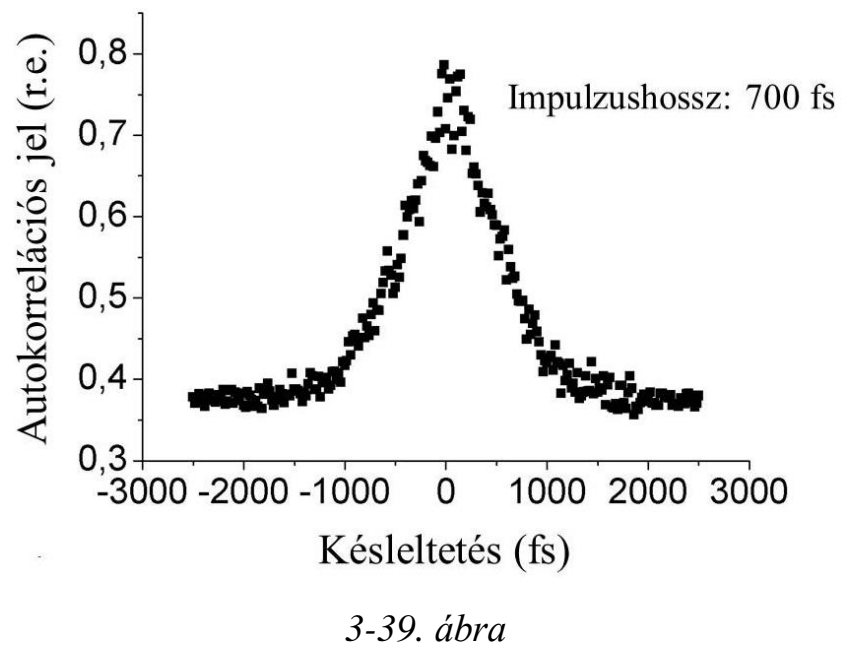

A rendszer kimentén mért impulzusok másodrendü autokorrelációs görbéje. A görbe félértékszélessége 700 fs impulzushossznak felel meg [120].

Az energiára és a terjedés térszögére kapott korábbi eredmények ismeretében, meghatározható az intenzitáskontraszt. A fenti adatok alapján a második előerősítő után az intenzitáskontraszt 4,5·10 ${ }^{11}$ értékü. A kimenő impulzusok fókuszált intenzitáskontrasztja 100 mJ-os kimenő energia esetén $9 \cdot 10^{10}$ értékü. Korábban ismertettem, hogy a rendszer kimentén 
mérhető ASE energiája nagymértékben függ a kontrasztjavítás után alkalmazott erősítés értékétől. Ennek következtében $50 \mathrm{~mJ}$ kimeneti energia esetén az intenzitáskontraszt már megközelíti a $10^{12}$ értéket.

Az impulzusidőnek az erősítési fokozatok számával összefüggő növekedése (3-38 és 3-39.ábra) az impulzus által egyre nagyobb mértékben elszenvedett fázismodulációra utal, amelyet az erősítőmodulok ablakai és az optikai elrendezésben lévő refraktív elemek okoznak. A lineáris optikai effektusokon túlmenően ekkora intenzitás mellett számolnunk kell nemlineáris effektusok megjelenésével is (pl.: önfázismoduláció). Ezért érdemesnek tartottam a $\mathrm{KrF}$ erősítési láncba bemenő és a rendszer végén kilépő impulzusok spektrumának összevetését. Az impulzusok spektrumát egy SPEX típusú rácsos spektrométerrel vizsgáltam. A bemenő és a kimenő impulzus spektrális intenzitáseloszlása a 3-40a. és b. ábra mutatja. Látható, hogy a bemenő spektrum szabályos Gauss eloszlást követ, ami egyrészt a frekvenciakétszerezés előtti impulzus (önfázismodulációt csak kismértékben tartalmazó) reguláris alakjának és a frekvenciakétszerezés simító hatásának következménye [122]. A kimenő impulzus spektrumán az erősítőmodulok és vákuumterek ablakaiban valamint a rendszerben lévő lencsékben fellépő önfázidmoduláció illetve az erősítés okozta spektrális hatások is látszódnak. Ugyanakkor lényeges eltérés nem mutatkozik a spektrum alakjában és félértékszélességében. A frekvenciakétszerezés valamint az ablakok által okozott önfázismoduláció és az erősítés spektrumra gyakorolt hatását a KrF lézerrendszerekben Nagy Tamás elméletileg és kísérletileg is vizsgálta. Erre vonatkozó eredményeinek részletes tárgyalása a doktori értekezésében megtalálható [76].
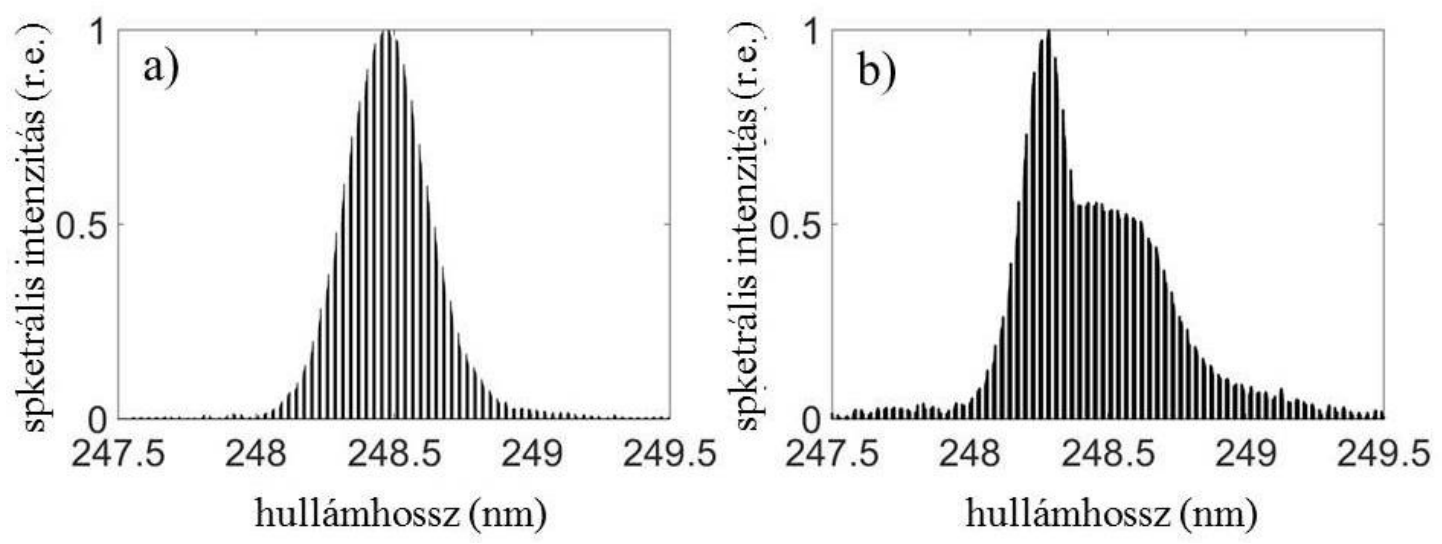

3-40. ábra

Az ultraibolya rövid impulzus erösitölánc elötti (a) és utáni (b) spektrális intenzitáseloszlása [120]. 


\section{4.d. Diszkusszió}

Ebben a fejezetben bemutattam a nemlineáris Fourier-szürés nagyintenzitású festékexcimer lézerrendszerbe integrálásával kapcsolatos kísérleti eredményeimet. A nemlineáris Fourier-szürőt a - három $\mathrm{KrF}$ excimer erősítőt tartalmazó - erősítőlánc első és második előerősítője közé integráltam. A kimeneten az impulzusok energiája elérte a $100 \mathrm{~mJ}$-t és a fókuszált intenzitáskontrasztja megközelítette a $10^{11}$ értéket. A kimeneten mérhető erősített spontán emisszió energiája nagymértékben függött a szürés után alkalmazott erősítés értékétől; $50 \mathrm{~mJ}$ kimenő energia mellett a kontraszt megközelítette a $10^{12}$ értéket. Mivel a nyaláb kétszeresen diffrakció-limitált, ezért egy f/2-es f-számú optika esetén lehetőség nyílik fény-anyag kölcsönhatási kísérletek végrehajtására $10^{19} \mathrm{~W} / \mathrm{cm}^{2}$ fókuszált intenzitás és $10^{12}$ intenzitáskontraszt mellett $248 \mathrm{~nm}$ hullámhosszon. A fent leírt lézerrendszer egyediségénél fogva számos alkalmazás kísérleti eszköze lehet. A korábban kifejlesztett csúcsteljesítményben hasonló paraméterű rendszerek [80] esetén nem közöltek kontrasztra vonatkozó adatot, de a Kísérleti Fizika Tanszék HILL laboratóriumában korábban müködő rendszer paramétereire vonatkozó tapasztalataim szerint a fókuszált intenzitáskontraszt bizonyosan nem haladta meg a $10^{9}$ értéket. Ennek megfelelően az intenzitáskontraszt 2-3 nagyságrenddel való javulása jelentős eredménynek tekinthető. Ugyanakkor érdemes megjegyezni, hogy a nemlineáris Fourier-szürés által elméletileg és kísérletileg jósolt (>5 nagyságrend) kontrasztjavulást nem sikerült realizálni a kimeneten.

A fent leírt lézerrendszer impulzusainak karakterizálása során bizonyítást nyert, hogy a rendszer kimentén mérhető ASE egésze a nemlineáris szürő után keletkezik. Ennek megfelelően az elérhető kontrasztot a nemlineáris szürő utáni erősítő láncban keletkező ASEnek a vártnál nagyobb mértékü erősödése szabja meg. Az elérhető kontrasztjavuláshoz az ASE erősítési dinamikáját is érdemes részletesen tanulmányozni. Mint azt a 3.4.a. alpontban is kifejtettem, a nagyintenzitású KrF rendszerek további kontrasztjavítása lehetséges ha az időszürési technika közvetlenül a végerősítő előtt vagy esetleg az után kerül alkalmazásra. Ennek feltétele, hogy a nemlineáris Fourier-szürést (vagy a plazma tükör technikát) nagyobb energiájú és átmérőjü nyalábokra is megbízhatóan lehessen alkalmazni. 


\section{4. Összefoglalás}

Az elmúlt évtizedekben a lézer technológia fejlődése nagyszámú új tudományos eredmény létrejöttéhez járult hozzá a fizika, az orvostudomány, a biológia és az anyagtudományok területén. Emellett a lézerek ipari alkalmazása is dinamikus növekedést mutat többek között a mikro és nano anyagmegmunkálásban. A tudományos kutatásban elért eredmények jelentős része a lézerekkel elérhető csúcsintenzitáshoz illetve az ehhez kapcsolódó széles spektrális tartományt lefedő másodlagos forrásokhoz köthető. Az ezen kísérleteknél használt impulzusok csúcsintenzitásának növelésén túl a tudományos kutatásban egyre növekvő szerepet kap az impulzusok tér- és időbeli minőségének javítása. Különös jelentősége van a főimpulzust időben megelőző, több nagyságrenddel kisebb előimpulzusnak ugyanis ez előplazmát kelthet, ami jelentősen befolyásolja a fény-anyag kölcsönhatási kísérletek eredményét.

A kísérleti munkám során nagyintenzitású ultraibolya rövid impulzusok kontrasztjavítását tüztem ki célul. Ezen impulzusok alkalmazása számos kölcsönhatás esetén (a rövidebb hullámhosszból fakadó nagyobb fotonenergia és jobb fókuszálhatóság miatt) előnyös és az infravörös tartományba eső rövid impulzusok komplementer fényforrásaként tekinthető. A disszertációmban bemutattam a legelterjedtebb nagyintenzitású lézerrendszerek felépítését és az ezekben sikerrel alkalmazott kontrasztjavító eljárásokat. A munkám során elért új tudományos eredményeket az alábbi tézispontokban foglalom össze.

1. Kísérletileg kimutattam, hogy ultraibolya rövid impulzusokkal kvarc céltárgyon keltett plazma reflexiója megközelíti a 70\%-ot, amely a szakirodalomban publikált eddigi legmagasabb érték $248 \mathrm{~nm}$ hullámhosszra. A plazma tükör technikára alapozva kifejlesztettem egy kísérleti eljárást, amellyel nagyintenzitású KrF excimer lézerrendszerek intenzitáskontrasztja több mint két nagyságrenddel javítható. Kísérletileg megmutattam, hogy a nyaláb ideálishoz közeli fókuszálhatósága a reflexió során nem változik. Megállapítottam, hogy az adott kísérleti elrendezés mellett a reflexió értéke jó közelítéssel független a nyaláb polarizációjától és attól, hogy az impulzusidő 500 fs vagy 220 fs. [115]

A rövid ultraibolya impulzusokkal keltett plazma reflexióját $~ 30$-as f-számú fókuszálás mellett anti-reflexiós bevonattal ellátott sík kvarc céltárgyon vizsgáltam. A 70\%-ot megközelítő reflexiót $\mathrm{s}$ és p polarizált nyaláb esetében is $1 \cdot 10^{15}-5 \cdot 10^{15} \mathrm{~W} / \mathrm{cm}^{2}$ intenzitás esetén lehetett mérni 500 fs impulzushossz esetén valamint $12^{\circ}$-os beesési szög mellett. A 
plazma tükör müködést 220 fs-os kompresszált impulzusra is demonstráltam, ahol a reflexió értéke valamivel kisebb 55\%-os értéket ért el, ami az impulzus tér- és időbeli minőségi romlásának tulajdonítható. A nyaláb távoli zónabeli eloszlását a reflexió előtt és után is megmértem. A fókuszfolt mérete a diffrakció-limitált elvi foltméret 1,5 ill. 1,75-szöröse volt. A nagy- és kisjelű reflexió hányadosából adódó több mint 2 nagyságrendbeli intenzitáskontraszt javulás, a reflektált nyaláb jó térbeli tulajdonságainak figyelembe vételével egy hatékony impulzusszürési eljárást eredményez nagyintenzitású ultraibolya $\mathrm{KrF}$ lézerrendszerek esetén.

\section{Elméleti modellt dolgoztam ki a nemlineáris Fourier-szürés kontrasztjavítását} korlátozó optikai leképezés térbeli kontrasztjának vizsgálatára. Az általam írt szimuláció segítségével megmutattam, hogy a korábban használt kísérleti elrendezésre illesztett leképezés esetén a térbeli kontraszt limit $10^{3}$ értékü. A leképezés térbeli kontrasztjának javítására a tárgy térfrekvenciás komponenseinek a leképező rendszerhez való illesztését javasoltam egy kis nyílásszögü leképezés és egy második tárgy apertúra alkalmazásával. Kimutattam, hogy az így előállított tárgy leképezés utáni térbeli kontrasztjának elméleti értéke nagyobb, mint $10^{8}$ [118].

Az optikai képalkotást a lineáris rendszereket leíró térfrekvenciás analízis segítségével vizsgáltam. Az általam fejlesztett szimuláció alkalmas térben koherens és inkoherens megvilágítást is kezelni. A kísérleti esetnek megfelelő $500 \mathrm{~cm}^{-1}$ levágási frekvenciájú esetben a kép térbeli kontrasztjára a szimuláció által kapott érték megegyezik a kísérletileg tapasztalt $\sim 10^{3}$ értékkel. Megmutattam, hogy a leképezés nyílásszögének növelésével javul, a leképezési hibák által okozott fázishibák növekedésével pedig romlik a leképezés kontrasztja. Az optikai leképezés kontrasztjának javítása céljából megvizsgáltam a leképező rendszer pupillafüggvényének apodizációját, ami a számolásaim szerint több nagyságrendnyi javulást eredményez. A technikai egyszerüségénél fogva elönyösebbnek bizonyult a tárgy nagy térfrekvenciás komponenseinek csökkentése. Ehhez az eredeti gyürü alakú éles tárgyat először egy kis nyílásszögü optikai elrendezéssel leképezzük, majd az így előálló eloszlás $10^{-3}$ normált intenzitásszint alatti részeit egy második apertúrával kitakarjuk. Ezt a modulált térfrekvenciás komponensekkel bíró tárgyat, a szimuláció szerint $10^{8}$ érétket meghaladó kontraszttal lehet a továbbiakban - normál paraméterekkel rendelkező optikai leképező rendszerekkel - leképezni. 
3. Kísérletileg kimutattam, hogy az optikai látható tartományban a nemlineáris Fourierszürési elrendezés részét képező leképezés térbeli kontrasztja nagyobb, mint $10^{7}$ értékre javítható a leképezendő tárgy nagy térfrekvenciás komponenseinek a modulációjával. Kísérletileg meghatároztam a nemlineáris Fourier-szürő intenzitásfüggő transzmissziógörbéjét. Kimutattam, hogy a szürő bemeneteként szolgáló tárgy térfrekvenciás modulációjával a kisjelü transzmisszió a korábbi $10^{-3}$ értékről (a mérőrendszer által detektálható legkisebb értékre) $10^{-5}$ alá csökken. Ezen eredményre alapozva kísérleti eljárást fejlesztettem ki ultraibolya rövid impulzusok 5 nagyságrenddel történő kontrasztjavítására. Kísérletileg karakterizáltam a nemlineáris Fourier-szürő kimenetén megjelenő nyaláb térbeli tulajdonságait [118].

A nagy térbeli kontraszttal leképezni kívánt gyürü alakú tárgy térfrekvenciás eloszlását egy kis nyílásszöget megengedő elő-leképezéssel moduláltam és az így kapott kép $10^{-3}$ intenzitásszint alatti részeit pedig egy újabb apertúrával takartam ki. Az így nyert csökkentett térfrekvenciás komponensekkel bíró új tárgy leképezése során $10^{7}$-t meghaladó térbeli kontraszt értéket mértem, tehát több mint 5 nagyságrenddel növeltem a leképezés kontrasztját a látható tartományban. Kísérleti úton megvizsgáltam a nemlineáris Fourier-szüréssel elérhető kontrasztjavulást a nagyjelü és a kisjelü transzmisszió mérésével. A tárgy térfrekvenciás komponenseinek modulációjával kiegészített elrendezés kisjelü transzmissziója $<10^{-5}$ értékre javult. A kapott értéket az energiamérő rendszer dinamikus tartománya szabta meg; a $\sim 4 \cdot 10^{12} \mathrm{~W} / \mathrm{cm}^{2}$ intenzitás alatti impulzusok kimenő energiáját nem tudtam detektálni. A szürt nyaláb térbeli tulajdonságait tekintve a távoli zónában szabályos Gauss eloszlást követ és a foltméret a diffrakció által megszabott elvi érték 1,75-szöröse.

4. Speciális fényforrást fejlesztettem ki nagyintenzitású és nagykontrasztú ultraibolya impulzusokkal történő fény-anyag kölcsönhatás vizsgálatára. Megépítettem egy ultraibolya rövid impulzusokra szabott, három KrF excimer erősítőmodulból álló erősítőláncot, amelyben az intenzitáskontraszt javítása céljából az első erősítő után egy nemlineáris Fourier-szűrési elrendezést integráltam. Az erősített impulzusok karakterizálásával megmutattam, hogy $10^{12}$ intenzitáskontraszt mellett megfelelő nyílásszögü fókuszálás esetén elméletileg $10^{19} \mathrm{~W} / \mathrm{cm}^{2}$ intenzitás érhető el [120].

A rövid impulzusú festéklézerrendszer által generált impulzusokat frekvenciakétszerezés után egy - lépésekben növekvő keresztmetszetü - három fokozatú $\mathrm{KrF}$ erősítőláncban erősödnek, ahol a kimeneten a nyalábméret eléri a $\sim 4 \times 4 \mathrm{~cm}^{2}$-t. A nemlineáris 
Fourier-szürési elrendezést a két erősítési átmenetben használt előerősítők közé integráltam. A hatékonyabb kontrasztjavítás érdekében a térfrekvencia modulációt biztosító elő-leképezés a második erősítési átmenet részét képezi. A szürés után előálló szub-mJ energiájú, extrém nagy kontraszttal rendelkező impulzusokat a második előerősítő és a két résznyalábos multiplexelési elrendezéssel kiegészített végerősítő a $100 \mathrm{~mJ}$ energiaszintre erősíti. Az impulzus időbeli karakterizálását másodrendủ autokorrelátorral és a spektrális intenzitás mérésével végeztem. A térbeli karakterizálást a közeli és távoli zóna vizsgálatával végeztem. A 700 fs időbeli hosszúságú és 2-szeresen diffrakció-limitált, reguláris térbeli eloszlású impulzusok fókuszált intenzitása egy f/2-es fókuszálás esetén elméletileg meghaladja a $10^{19} \mathrm{~W} / \mathrm{cm}^{2}$ intenzitást. A kísérleti tapasztalat szerint az intenzitáskontrasztot meghatározó erősített spontán emisszió a mérés határain belül kizárólag a nemlineáris Fourier-szűrés után keletkezik, melynek energiája erősen függ a szürés után alkalmazott erősítés mértékétől. A kimenő energia $100 \mathrm{~mJ}$ és $50 \mathrm{~mJ}$ közötti megválasztása esetén az intenzitáskontraszt a fókuszsíkban $10^{11}-10^{12}$ értékü. 


\section{Summary}

The remarkable progress of laser technology in the last decades allowed breaking scientific results in various fields including physics, medicine, biology, and material science. The industrial application of lasers has an increasing importance like in laser based micro/nano machining. The driving force behind many of these applications is the improvement of the peak intensity of laser systems and the extension of the wavelength range of secondary sources. The investigation and improvement of the spatio-temporal quality of ultrashort laser pulses plays an ever increasing role in high intensity physics. Most of the applications of high-intensity laser pulses require extremely high temporal and spatial quality. Temporal prepulses are especially detrimental for high intensity laser-matter interactions, as the lower intensity prepulse may generate a preplasma preventing direct interaction between the main pulse and the material to be studied.

In my thesis the construction and the main features of high-intensity lasers systems are reviewed with emphasis on the available contrast improvement techniques. I investigated the contrast improvement of high-brightness ultraviolet short pulses, which are advantageous for numerous interactions, due to the shorter wavelength and the resulting higher photon energy and better focusability. Ultraviolet high-intensity lasers can be regarded as complementary sources of the most commonly used infrared ultrashort pulses. My new scientific results are summarized in the following 4 sections.

1. It has been experimentally demonstrated that $70 \%$ reflectivity of plasma generated by ultraviolet short pulses can be reached on quartz target, which is the highest published value at $248 \mathrm{~nm}$ by this time. Based on this plasma mirror effect an experimental arrangement has been developed for high-intensity $\mathrm{KrF}$ laser systems, offering contrast improvement of more than two orders of magnitude. It has been demonstrated that the focusability of the filtered beam is unchanged, moreover the reflectivity is practically independent of the polarization of the beam and of the pulse duration (measured for 500 fs and 220 fs pulses) [115].

The reflection of the plasma was measured on an anti-reflection coated quartz target with $\mathrm{f} / 30$ focusing. The reflectivity approached $70 \%$ for $12^{\circ}$ of angle of incidence both for s and $\mathrm{p}$ polarized beam at the $1 \cdot 10^{15}-5 \cdot 10^{15} \mathrm{~W} / \mathrm{cm}^{2}$ intensity range, when the pulse width was 500 fs. The plasma mirror effect was also demonstrated for shorter (220 fs long) pulses, where the maximum reflectivity was somewhat moderate $\sim 55 \%$. This is likely connected to 
the less optimum temporal and spatial quality of the beam. The focal distribution of the beam was measured before and after reflection; the diameter of the focal spot was 1.5 and 1.75 times of the diffraction-limited size, respectively. Regarding the achievable contrast improvement of $>2$ orders of magnitude - defined by the ratio of the high and low intensity reflection - and the good spatial distribution of the reflected beam this approach can be regarded as an efficient filtering technique for high-intensity $\mathrm{KrF}$ laser systems.

2. A theoretical model has been developed to investigate the achievable contrast improvement of the nonlinear Fourier-filter. The numerical simulation showed that the limitation is imposed by the spatial contrast of optical imaging; restraining the maximum contrast in our experimental case to $10^{3}$. It was suggested that an object is better suited to high contrast imaging if the spatial frequency spectrum of the object is modulated by a low numerical aperture pre-imaging and this image is completed by a second aperture. It was shown by numerical calculations that such an object can further be imaged with higher than $10^{8}$ spatial contrast [118].

The spatial contrast of optical imaging was studied by the use of frequency analysis of linear systems. This simulation can handle spatially coherent and incoherent illumination. For an imaging system of $500 \mathrm{~cm}^{-1}$ cut-off frequency the simulation showed good agreement with the experimentally obtained value for the spatial contrast of imaging. It was shown that with increasing solid angle (or resolution) of imaging the spatial contrast increases. However, the eventually increasing phase front error of aberrations decreases the spatial contrast. It was demonstrated that the apodization of the exit pupil of the imaging system can improve the available spatial contrast by several orders of magnitude. For practical reasons another approach - based on the controlled modulation of the spatial frequency spectrum by decreasing the role of the high spatial frequency components - is more preferable. We realized this by applying a low numerical aperture imaging and a secondary beam-block in the image plane of this pre-imaging to exclude the areas of normalized intensity below $10^{-3}$. An object of such spatial frequency distribution can be imaged with a spatial contrast greater than $10^{8}$.

3. It was experimentally demonstrated that the imaging system of the nonlinear Fourierfilter operating the visible wavelength range can be improved by the spatial frequency modulation of the object, resulting in a spatial contrast as high as $10^{7}$. The improvement of the contrast of imaging was also experimentally demonstrated for ultraviolet short pulses by measuring the intensity dependent throughput of the nonlinear Fourier-filter. 
Using an object of controlled spatial frequencies the small signal throughput decreased from $10^{-3}$ to $10^{-5}$ - determined by the limited dynamic range of the measurement. Based on this results an experimental arrangement is suggested to improve the intensity contrast of high-intensity UV pulses by more than 5 orders of magnitude. The spatial features of the filtered pulses are also characterized [118].

The new object of modulated spatial frequency was created by a combination of a low numerical aperture pre-imaging and a secondary beam-block in the image plane which excluded the areas of normalized intensity below $10^{-3}$ of the intermediate image. This modulated object could be imaged with a spatial contrast of $10^{7}$. This corresponds to 5 orders of magnitude improvement in the visible wavelength range. The achievable contrast improvement of the nonlinear Fourier-filter was determined by measuring the intensity dependent throughput. By the use of the frequency modulated object the low intensity transmission decreased below $10^{-5}$. This value was limited by the dynamic range of the measurement; pulses of focused intensity below $\sim 4 \cdot 10^{12} \mathrm{~W} / \mathrm{cm}^{2}$ could not be detected. As far as the spatial features of the filtered beam are concerned, the far field distribution of the beam has a regular Gaussian shape with 1.75 times larger spot diameter than the diffraction-limit.

4. A special light source has been developed for the investigation of laser-matter interaction at high-intensity and high temporal contrast. An UV short-pulse amplifier chain - containing three KrF excimer amplifiers - has been constructed where the nonlinear Fourier-filtering technique is integrated into the system after the first preamplifier. Characterization of the output pulses showed that with sufficiently low F-number focusing $10^{19} \mathrm{~W} / \mathrm{cm}^{2}$ intensity can be achieved with $10^{12}$ intensity contrast in the focal plane [120].

The short pulses - generated by the sub-picosecond dye laser system - after frequency conversion are amplified in a $\mathrm{KrF}$ amplifier chain consisting of three gain modules of increasing cross-section, up to an output beam size of $\sim 4 \mathrm{x} 4 \mathrm{~cm}^{2}$. The two preamplifiers are used in a double pass arrangement and the nonlinear Fourier-filter is integrated between them. To promote effective pulse filtering the pre-imaging is done during the second amplification pass of the first preamplifier. The high contrast pulses of sub-mJ energy are then amplified in the second preamplifier and in the final amplifier - which uses a two beam interferometric multiplexing setup - up to $100 \mathrm{~mJ}$. The temporal characterization of the pulse was based on second order autocorrelator and spectral intensity measurement. Both the near and far field 
spatial intensity distribution of the beam was also recorded. The expected focused intensity with $\mathrm{f} / 2$ focusing - of the 2 times diffraction limited and $700 \mathrm{fs}$ long pulses is in excess of $10^{19} \mathrm{~W} / \mathrm{cm}^{2}$. Based on our experiments the temporal background of the output is determined by the amplified spontaneous emission generated solely after the nonlinear Fourier-filter. The energy of the ASE strongly depends on the gain of the amplifier chain following the filter. For different values of this gain an intensity contrast between $10^{11}$ and $10^{12}$ is obtained in the focal plane. 


\section{Köszönetnyilvánítás}

Ezúton szeretnék köszönetet mondani témavezetőmnek Dr. Szatmári Sándor professzornak a kutatási témába való bevezetésért és a kísérleti feltételek biztosításáért. Az értekezésemben bemutatott eredmények elsősorban közös munka eredménye, elvi meggondolások és praktikus javaslatok felvetésével nagymértékben elősegítette a kutatási eredmények létrejöttét. Ugyancsak szeretnék köszönetet mondani Dr. Földes István tudományos fömunkatársnak (Wigner Fizikai Kutatóközpont, Plazmafizikai Osztály) a plazma tükör vizsgálata kapcsán kapott hasznos szakmai tanácsaiért és a téma felvetéséért valamint az értekezés kapcsán tett értékes kritikai megjegyzéseiért.

Köszönetemet fejezem ki Kovács Zsolt PhD hallgatónak és Homik Zsolt Fizikus MSc hallgatónak a közösen végzett kutatások során nyújtott segítségükért valamint a Kísérleti Fizikai Tanszéken müködő elektromos és mechanikus mühely dolgozóinak a technikai segítségért.

Köszönettel tartozom Dr. Nánai László professor emeritusnak és Dr. Szörényi Tamásnak az értekezés kéziratának átolvasásáért és értékes kritikai megjegyzéseikért.

Köszönetet mondok Dajka Rita tudományos segédmunkatársnak a labor adminisztratív ügyeinek intézéséért továbbá a Kisérleti Fizikai Tanszék valamint a Fizikai Intézet tagjainak a mindennapi munkám során nyújtott segítségükért.

Nagy hálával tartozom családomnak és barátaimnak a munkámhoz nyújtott támogatásukért és folyamatos bíztatásukért.

Kutatási eredményeim az Európai Unió támogatásával, az Európai Szociális Alap társfinanszírozásával, az EFOP-3.6.2-16-2017-00005, azonosítószámú, „Ultragyors fizikai folyamatok atomokban, molekulákban, nanoszerkezetekben és biológiai rendszerekben" projekt segítségével jöttek létre. 


\section{Irodalomjegyzék}

[1] D. Strickland, G. Mourou, "Compression of amplified chirped optical pulses," Opt. Comm., 55, 447, 219 (1985).

[2] V. Yanovsky, V. Chvykov, G. Kalinchenko, P. Rousseau, T. Planchon, T. Matsuoka, A. Maksimchuk, J. Nees, G. Cheriaux, G. Mourou, K. Krushelnick, "Ultra-high intensity- 300-TW laser at $0.1 \mathrm{~Hz}$ repetition rate," Opt. Express 16, 3, 2109 (2008).

[3]. Z. Wang, C. Liu, Z. Shen, Q. Zhang, H. Teng, Z. Wei, "High-contrast 1.16 PW Ti:sapphire laser system combined with a doubled chirped-pulse amplification scheme and a femtosecond opticalparametric amplifier, "' Opt. Lett. 36, 16, 3194 (2011).

[4] M. Martinez, W. Bang, G. Dyer, X. Wang, E. Gaul, T. Borger, M. Ringuette, M. Spinks, H. Quevedo, A.Bernstein, M. Donovan, T. Ditmire, "The Texas petawatt laser and current experiments," AIP Conf. Proc.1507, 874 (2012).

[5] F. Wagner, C. P. João, J. Fils, T. Gottschall, J. Hein, J. Körner, J. Limpert, M. Roth, T. Stöhlker, V. Bagnoud, "Temporal contrast control at the PHELIX petawatt laser facility by means of tunable sub-picosecond optical parametric amplification,” Appl. Phys. B 116, 2, 429 (2014).

[6] T. M. Jeong, J. Lee, “Femtosecond petawatt laser,” Ann. Phys. 526, 3-4, 157 (2014).

[7] Sudipta Mondal, Mojtaba Shirozhan, Naveed Ahmed, Maïmouna Bocoum, Frederik Boehle, Aline Vernier, Stefan Haessler, Rodrigo Lopez-Martens, François Sylla, Cedric Sire, Fabien Quéré, Kwinten Nelissen, Katalin Varjú, Dimitris Charalambidis, Subhendu Kahaly, "Surface plasma attosource beamlines at ELI-ALPS," J. Opt. Soc. Am. B 35, A93-A102 (2018)

[8] K. Osvay, A. Börzsönyi, D. Charalambidis, E. Cormier, L. Fülöp, M. Kalashnikov, C. Kamperidis, B. Kiss, R. Lopez-Martens, G. Sansone, Z. Várallyay, K. Varjú, "First Intense, phase controlled, few cycle laser sources in the ELI Attosecond Facility," in Conference on Lasers and Electro-Optics, OSA Technical Digest paper STu3M.3. (2018).

[9] N. Thiré, R. Maksimenka, B. Kiss, C. Ferchaud, P. Bizouard, S. Jarosch, V. Di Pietro, É. Cormier, K. Osvay, N. Forget, "A 15 W, Few-Cycle and Ultra-Stable Mid-infrared Parametric Source for ELI$A L P S, "$ in High-Brightness Sources and Light-driven Interactions, OSA Technical Digest paper HW4A.4. (2018).

[10] T. Levato, S. Bonora, G.M. Grittani, C.M. Lazzarini, M.F. Nawaz, M. Nevrkla, L. Villanova, R. Ziano, S. Bassanese, N. Bobrova, K. Casarin, E. Chacon-Golcher, Y. Gu, D. Khikhlukha, D. Kramer, M. Lonza, D. Margarone, V. Olšovcová, M. Rosinski, B. Rus, P. Sasorov, R. Versaci, A. ZaraśSzydłowska, S.V. Bulanov, G. Korn, "HELL, High-Energy Electrons by Laser Light, a User-Oriented Experimental Platform at ELI Beamlines," Appl. Sci., 8, 1565 (2018).

[11] S. Weber, S. Bechet, S. Borneis, L. Brabec, M. Bučka, E. Chacon-Golcher, M. Ciappina, M. DeMarco, A. Fajstavr, K. Falk, E.-R. Garcia, J. Grosz, Y.-J. Gu, J.-C. Hernandez, M. Holec, P. Janečka, M. Jantač, M. Jirka, H. Kadlecova, D. Khikhlukha, O. Klimo, G. Korn, D. Kramer, D. Kumar, T. Lastovička, P. Lutoslawski, L. Morejon, V. Olšovcová, M. Rajdl, O. Renner, B. Rus, S. Singh, M. Šmid, M. Sokol, R. Versaci, R. Vrána, M. Vranic, J. Vyskočil, A. Wolf, Q. Yu, ”An installation for high-energy density plasma physics and ultra-high intensity laser-matter interaction at ELI-Beamlines, " Matter and Radiation at Extremes 2, 4, 149 (2017)

[12] R. Antipenkov, F. Batysta, R. Boge, E. Erdman, M. Greco, J. T. Green, B. Himmel, M. Horáček, Z. Hubka, L. Indra, K. Majer, T. Mazanec, P. Mazurek, J. Naylon, J. Novák, V. Šobr, A. Špaček, P. Strkula, M. Torun, B. Tykalewicz, P. Bakule, B. Rus, "The construction of Allegra kilohertz femtosecond laser system at ELI-Beamlines, " Proc. SPIE 11034, 110340M (2019) 
[13] V. Zamfir, K. Tanaka, C. Ur, "Extreme light infrastructure nuclear physics (ELI-NP)," Europhysics News, 50, 2, 23 (2019)

[14] J. Faure, Y. Glinec, A. Pukhov, S. Kiselev, S. Gordienko, E. Lefebvre, J.-P. Rousseau, F. Burgy, V. Malka, "A Laser-Plasma Accelerator Producing Monoenergetic Electron Beams," Nature (London) 431, 541 (2004).

[15] C. G. R. Geddes, Cs. Tóth, J. Van Tilborg, E. Esarey, C. B. Schroeder, D. Bruhwiler, C. Nieter, J. Cary, W. P. Leemans, "High-Quality Electron Beams from a Laser Wakefield Accelerator Using Plasma-Channel Guiding," Nature (London) 431, 538 (2004).

[16] W. P. Leemans, A. J. Gonsalves, H.-S. Mao, K. Nakamura, C. Benedetti, C. B. Schroeder, Cs. Tóth, J. Daniels, D. E. Mittelberger, S. S. Bulanov, "Multi-GeV Electron Beams from CapillaryDischarge-Guided Subpetawatt Laser Pulses in the Self-Trapping Regime," Phys. Rev. Lett. 113, 24, 245002 (2014).

[17] R. A. Snavely, M. H. Key, S. P. Hatchett, T. E. Cowan, M. Roth, T. W. Phillips, M. A. Stoyer, E. A. Henry, T. C. Sangster, M. S. Singh, S. C. Wilks, A. MacKinnon, A. Offenberger, D. M. Pennington, K. Yasuike, A. B. Langdon, B. F. Lasinski, J. Johnson, M. D. Perry, E. M. Campbell,"Intense high-energy proton beams from petawatt-laser irradiation of solids, " Phys. Rev. Lett. 85, 2945 (2000).

[18] S. P. Hatchett, C. G. Brown, T. E. Cowan, E. A. Henry, J. S. Johnson, M. H. Key, J. A. Koch, A. B. Langdon, B. F. Lasinski, R. W. Lee, A. J. Mackinnon, D. M. Pennington, M. D. Perry, T. W. Phillips, M. Roth, T. C. Sangster, M. S. Singh, R. A. Snavely, M. A. Stoyer, S. C. Wilks, K. Yasuike,"Electron, photon, and ion beams from the relativistic interaction of petawatt laser pulses with solid targets, " Phys. Plasmas 72076 (2000).

[19] H. Daido, M. Nishiuchi, A. S. Pirozhkov, "Review of laser-driven ion sources and their applications, ” Rep. Prog. Phys. 75056401 (2012).

[20] F. Wagner, O. Deppert, C. Brabetz, P. Fiala, A. Kleinschmidt, P. Poth, V. A. Schanz, A. Tebartz, B. Zielbauer, M. Roth, T. Stöhlker, V. Bagnoud,"Maximum proton energy above $85 \mathrm{MeV}$ from the relativistic interaction of laser pulses with micrometer thick $\mathrm{CH}_{2}$ targets," Phys. Rev. Lett. 116 205002 (2016).

[21] H. Chen, S. C. Wilks, J. D. Bonlie, S. N. Chen, K. V. Cone, L. N. Elberson, G. Gregori, D. D. Meyerhofer, J. Myatt, D. F. Price, M. B. Schneider, R. Shepherd, D. C. Stafford, R. Tommasini, R. Maren, P. Beiersdorfer, "Making relativistic positrons using ultraintense short pulse lasers," Phys. Plasmas 16, 122702 (2009).

[22] A. Rousse, K. T. Phuoc, R. Shah, A. Pukhov, E. Lefebvre, V. Malka, S. Kiselev, F. Burgy, J. P. Rousseau, D. Umstadter, D. Hulin, "Production of a keV X-Ray Beam from Synchrotron Radiation in Relativistic Laser-Plasma Interaction," Phys. Rev. Lett. 93, 135005 (2004).

[23] K. Ta Phuoc, S. Corde, C. Thaury, V. Malka, A. Tafzi, J. P. Goddet, R. C. Shah, S. Sebban, A. Rousse, "All-Optical Compton Gamma-Ray Source," Nat. Photonics 6, 308 (2012).

[24] S. Chen, N. D. Powers, I. Ghebregziabher, C. M. Maharjan, C. Liu, G. Golovin, S. Banerjee, J. Zhang, N. Cunningham, A. Moorti, S. Clarke, S. Pozzi, D. P. Umstadter, "MeV-Energy X Rays from Inverse Compton Scattering with Laser-Wakefield Accelerated Electrons," Phys. Rev. Lett. 110, 155003 (2013).

[25] G. Sarri, D. J. Corvan, W. Schumaker, J. M. Cole, A. Di Piazza, H. Ahmed, C. Harvey, C. H. Keitel, K. Krushelnick, S. P. D. Mangles, Z. Najmudin, D. Symes, A. G. R. Thomas, M. Yeung, Z. Zhao, M. Zepf, "Ultrahigh Brilliance Multi-MeV $\gamma$-Ray Beams from Nonlinear Relativistic Thomson Scattering, ” Phys. Rev. Lett. 113, 224801 (2014). 
[26] R A Ganeev, "High-order harmonic generation in a laser plasma: a review of recent achievements, ” Journal of Physics B, 40, 22, 213 (2007).

[27] M. Hentschel, R. Kienberger, Ch. Spielmann, G. A. Reider, N. Milosevic, T. Brabec, P. Corkum, U. Heinzmann, M. Drescher, F. Krausz, ”Attosecond metrology,” Nature 414, 509 (2001).

[28] H. A. Hafez, X. Chai, A. Ibrahim, S. Mondal, D. Férachou, X. Ropagnol, T. Ozaki, "Intense terahertz radiation and their applications, ” J. Opt. 18093004 (2016).

[29] K. B. Wharton, C. D. Boley, A. M. Komashko, A. M. Rubenchik, J. Zweiback, J. Crane, G. Hays, T. E. Cowan, T. Ditmire, "Effects of nonionizing prepulses in high-intensity laser-solid interactions," Phys. Rev. E Stat. Nonlin. Soft Matter Phys. 64, 2, 025401 (2001).

[30] I. B. Földes, J. S. Bakos, K. Gál, Z. Juhász, M. A. Kedves, G. Kocsis, S. Szatmári, G. Veres, "Properties of high harmonics generated by ultrashort UV laser pulses on solid surfaces," Laser Phys. 10, 1, 264 (2000).

[31] P. Simon, J. Bekesi, C. Dölle, J.-H. Klein-Wiele, G. Marowsky, S. Szatmari, B. Wellegehausen, "Ultraviolet femtosecond pulses: key technology for sub-micron machining and efficient XUV pulse generation,” Appl. Phys. B 74(S1), 189 (2002).

[32] W. L. Kruer, “The physics of laser plasma interactions, ” Westview Press, (2003).

[33] F. G. Omenetto, K. Boyer, J. W. Longworth, A. McPherson, T. Nelson, P. Noel, W. A. Schroeder, C. K. Rhodes, S. Szatmári, G. Marowsky, "High-brightness terawatt $\mathrm{KrF}^{*}(248 \mathrm{~nm})$ system, ” Appl. Phys. B 64, 6, 643 (1997).

[34] S. Szatmári, G. Almási, M. Feuerhake, P. Simon, "Production of intensities of $10^{\wedge} 19 \mathrm{~W} / \mathrm{cm}^{\wedge} 2$ by a table-top KrF laser,” Appl. Phys. B 63, 5, 463 (1996).

[35] J. Békési, S. Szatmári, P. Simon, G. Marowsky, "Table-top KrF amplifier delivering 270 fs output pulses with over 9 W average power at 300 Hz,” Appl. Phys. B 75, 4, 521 (2002).

[36] I. B. Földes, A. Barna, D. Csáti, F. L. Szücs, S. Szatmári, ”Plasma mirror

effect with a short-pulse KrF laser, "J. Phys. Conf. Ser. 244, 032004 (2010).

[37] I. B. Földes, D. Csáti, F. L. Szücs, S. Szatmári, "Plasma mirror and temperature evolution for short pulse KrF lasers, ” Radiat. Eff. Defects Solids 165, 6-10, 429 (2010).

[38] S. Szatmári, R. Dajka, A. Barna, B. Gilicze, I. B. Földes, ”Improvement of the temporal and spatial contrast for high-brightness laser beams, ” Laser Phys. Lett. 13, 7, 075301 (2016).

[39] Gy. Farkas, Cs. Tóth, "Proposal for attosecond light pulse generation using laser induced multiple-harmonic conversion processes in rare gases, " Physics Letters A, 168, 5-6, 447 (1992).

[40] T. Ceccotti, A. Lévy, H. Popescu, F. Réau, P. D’Oliveira, P. Monot, J. P. Geindre, E. Lefebvre, P. Martin, "Proton Acceleration with High-Intensity Ultrahigh-Contrast Laser Pulses," Phys. Rev. Lett. 99, 18, 185002 (2007).

[41] A. Flacco, F. Sylla, M. Veltcheva, M. Carrié, R. Nuter, E. Lefebvre, D. Batani, V. Malka, "Dependence on pulse duration and foil thickness in high-contrast-laser proton acceleration," Phys. Rev. E Stat. Nonlin. Soft Matter Phys. 81, 3, 036405 (2010).

[42]. J. S. Green, A. P. L. Robinson, N. Booth, D. C. Carroll, R. J. Dance, R. J. Gray, D. A. MacLellan, P. McKenna, C. D. Murphy, D. Rusby, L. Wilson, "High efficiency proton beam generation through target thickness control in femtosecond laser-plasma interactions," Appl. Phys. Lett. 104, 21, 214101 (2014).

[43] T. R. Boehly, Y. Fisher, D. D. Meyerhofer, W. Seka, J. M. Soures, D. K. Bradley, "The effect of optical prepulse on direct-drive inertial confinement fusion target performance," Phys. Plasmas 8, 1, 231 (2001). 
[44] J. A. Cobble, G. T. Schappert, L. A. Jones, A. J. Taylor, G. A. Kyrala, R. D. Fulton, ”The interaction of a high irradiance, subpicosecond laser pulse with aluminum: The effects of the prepulse on x-ray production," J. Appl. Phys. 69, 3369 (1991).

[45] A. Tarasevitch, K. Lobov, C. Wunsche, D. von der Linde, 'Transition to the Relativistic Regime in High Order Harmonic Generation," Phys. Rev. Lett. 98, 103902 (2007).

[46] A. Rousse, C. Rishel, J.-C. Gauthier, "Colloquium: Femtosecond x-ray crystallography," Reviews of Modern Physics 73, 17 (2001).

[47] J. Workman, M. Nantel, M. Maksimchuk, D. Umstadter, ”Application of a picosecond soft x-ray source to time-resolved plasma dynamics," Appl. Phys. Lett. 70, 312 (1997).

[48] M. Roth, T. E. Cowan, C. Brown, M. Christl, W. Fountain, S. Hatchett, J. Johnson, M. H. Key, D. M.Pennington, M. D. Perry, T. W. Phillips, T. C. Sangster, "Intense ion beams accelerated by petawatt-class lasers, "Nuclear Instruments and Methods in Physics Research 464, 201 (2002).

[49] A. Rundquist, C. G. Durfee, Z. Chang, C. Herne, S. Backus, M. M. Murnane, H. C. Kapteyn, "Phase-Matched Generation of Coherent Soft X-rays," Americ. Assoc. Advanc. Sci. 280, 5368, 1412 (1998).

[50] A.P. Fews, P.A. Norreys, F.N. Beg, A.R. Bell, A.E. Dangor, C.N. Danson, P. Lee, S.J. Rose, "Plasma Ion Emission from High Intensity Picosecond Laser Pulse Interactions with Solid Targets," Phys. Rev. Lett. 73, 1801 (1994).

[51] D. E. Rivas, A. Borot, D. E. Cardenas, G. Marcus, X. Gu, D. Herrmann, J. Xu, J. Tan, D. Kormin, G. Ma, W. Dallari, G. D. Tsakiris, I. B. Földes, S. W. Chou, M. Weidman, B. Bergues, T. Wittmann, H. Schröder, P. Tzallas, D. Charalambidis, O. Razskazovskaya, V. Pervak, F. Krausz, L. Veisz, "Next Generation Driver for Attosecond and Laser-plasma Physics, ”Sci. Rep. 7, 5224 (2017).

[52] D. Guénot, D. Gustas, A. Vernier, B. Beaurepaire, F. Böhle, M. Bocoum, M. Lozano, A. Jullien, R. Lopez-Martens, A. Lifschitz, J. Faure, "Relativistic electron beams driven by $\mathrm{kHz}$ single-cycle light pulses, "Nat. Photonics 11, 293 (2017).

[53] A. Kessel, V. E. Leshchenko, O. Jahn, A. M. M. Krüger, A. Schwarz, V. Pervak, M. Trubetskov, S. A. Trushin, F. Krausz, Z. Major, S. Karsch, "Relativistic few-cycle pulses with high contrast from picosecond-pumped OPCPA," Optica 5, 4, 434 (2018).

[54] A. Dubietis, G. Jonušauskas, A. Piskarskas, "Powerful femtosecond pulse generation by chirped and stretched pulse parametric amplification in BBO crystal," Opt. Commun. 88, 4-6, 437 (1992)

[55] G. A. Mourou, T. Tajima, S. V. Bulanov, "Optics in relativistic regime," Rev. Mod. Phys. 78, 309 (2006)

[56] M. P. Kalashnikov, E. Risse, H. Schönnagel, W. Sandner, "Double chirped-pulse-amplification laser: a way to clean pulses temporally,” Opt. Lett. 30, 8, 923 (2005).

[57] C. H. K. Rhodes, ”Excimer lasers, ”2nd edition, Springer-Verlag, Berlin (1984).

[58] R. Burnham "A discharge pumped laser on the $C \rightarrow A$ transition of $X e F$," Appl. Phys. Lett. 35, 48 (1979).

[59] H. Egger, T. S. Luk, K. Boyer, D. F. Muller, H. Pummer, T. Srinivasan, C. K. Rhodes, "Picosecond, tunable ArF* excimer laser source," Appl. Phys. Lett. 41, 1032 (1982).

[60] K. Mossavi, Th. Hofmann, and F. K. Tittel, G. Szabó, "Ultrahigh-brightness, femtosecond ArF excimer laser system, ” Appl. Phys. Lett. 62, 1203 (1993).

[61] J. H. Glownia, G. Arjavalingam, P. P. Sorokin, J. E. Rothenberg, ”Amplification of 350-fsec pulses in XeCl excimer gain modules," Optics Letters 11, 2, 79 (1986).

[62] S. Watanabe, A. Endoh, M. Watanabe, N. Saukura, "Terawatt XeCl discharge laser system", Opt. Lett. 13, 7, 580 (1988). 
[63] S.Szatmári, B.Rácz, F.P.Schäfer, "Bandwidth limited amplification of $220 \mathrm{fs}$ pulses in XeCl," Opt. Comm. 62, 4, 271 (1987).

[64] S. Szatmári, F. P. Schäfer, "Comparative study of the gain dynamics of $\mathrm{XeCl}$ and $\mathrm{KrF}$ with subpicosecond resolution," J. Opt. Soc. Am. B 4, 1943 (1987).

[65] A. J. Taylor, C. R. Talhnan, J. P. Roberts, C. S. Lester, P. H. Y. Lee, and G. A. Kyrala, "Highintensity subpicosecond XeCl laser system," Opt. Lett. 15, 1, 39 (1990).

[66] Q. Zhao, S. Szatmári, F.P. Schäfer, "Gain dynamics of XeF and subpicosecond pulse generation at $351 \mathrm{~nm}$," Appl. Phys. B 47, 325 (1988).

[67] S. V. Alekseev, A. I. Aristov, Ya. V. Grudtsyn, N. G. Ivanov, B. M. Koval'chuk, V. F. Losev, S. B. Mamaev, G. A. Mesyats, L. D. Mikheev, Yu. N. Panchenko, A. V. Polivin, S. G. Stepanov, N. A. Ratakhin, V. I. Yalovoi, A. G. Yastremskii, "Visible-range hybrid femtosecond systems based on a XeF $(C-A)$ amplifier: state of the art and prospects, " Quantum Electron. 43, 3, 190 (2013).

[68] S. Szatmári, F. P. Schäfer, "Simplified laser system for the generation of $60 \mathrm{fs}$ pulses at $248 \mathrm{~nm}$," Opt. Commun. 68, 3, 196 (1988).

[69] A. Endoh, M. Watanabe, N. Sarukura, S. Watanabe, "Multiterawatt subpicosecond KrF laser," Opt. Lett. 14, 7, 353 (1989).

[70] S. Watanabe, A. Endoh, M. Watanabe, N. Saukura, K. Hata, "Multiterawatt excimer-laser system, ” J. Opt. Soc. Am. B 6, 10, 1870 (1989).

[71] I. N. Ross, A. R. Damerell, E. J. Divall, J. Evans, G. J. Hirst, C. J. Hooker, J. R. Houliston, M. H. Key, J. M. D. Lister, K. Osvay, M. J. Shaw, "A $1 T W$ KrF laser using chirped pulse amplification," Opt. Comm. 109, 3-4, 288 (1994).

[72] S. Szatmári, "High-brightness ultraviolet excimer lasers," Appl. Phys. B 58, 211 (1994).

[73] S. Szatmári, G. Marowsky and P. Simon, "Femtosecond excimer lasers and their applications," Landolt - Börnstein New Series pp. 215-253, Springer (2007).

[74] J. H. Klein-Wiele, T. Nagy, P. Simon, "Hollow-fiber pulse compressor for KrF lasers," Appl. Phys. B Lasers and Optics, 82, 4, 567 (2006).

[75] T. Nagy, P. Simon, "Generation of 200- $\mu J$, sub-25-fs deep-UV pulses using a noble-gas-filled hollow fiber," Opt. Lett. 34, 15, 2300 (2009).

[76] Nagy Tamás, "Nagy intenzitású KrF lézerek müködésének optimalizálása," PhD értekezés (2000).

[77] M. M. Tilleman, J. H. Jacob, "Short pulse amplification in the presence of absorption," Appl. Phys. Lett. 50, 121 (1987)

[78] G. Almàsi, S. Szatmári, P. Simon, "Optimized operation of short-pulse KrF amplifiers by off-axis amplification, " Opt. Commun. 88, 2-3, 231 (1992).

[79] S. Szatmári and P. Simon, "Interferometric multiplexing scheme for excimer amplifiers," Opt. Commun. 98, 1-3, 181 (1993).

[80] J. Békési, G. Marowsky, S. Szatmári, P. Simon, "A 100 mJ table-top short pulse amplifier for 248 nm using interferometric multiplexing,” Z. Phys. Chem. 215, 12, 1543 (2001).

[81] A. B. Borisov, J. C. McCorkindale, S. Poopalasingam, J. W. Longworth, P. Simon, S. Szatmári, C. K. Rhodes, "Rewriting the rules governing high intensity interactions of light with matter," Rep. Prog. Phys. 79, 4, 046401 (2016).

[82] A. Fernandez, T. Fuji, A. Poppe, A. Furbach, F. Krausz, A. Apolonski, "Chirped-pulse oscillators: a route to high-power femtosecond pulses without external amplification," Opt. Lett. 29, 12, 1366 (2004). 
[83] J. Itatani, J. Faure, M. Nantel, G. Mourou, S. Watanabe, "Suppression of the amplified spontaneous emission in chirped-pulse-amplification lasers by clean high-energy seed-pulse injection," Optics Comm. 148, 1-3, 70 (1998).

[84] J. Wojtkiewicz, C.G. Durfee, "High-energy, high-contrast, double-confocal multipass amplifier," Opt. Express 12, 7, 1383 (2004).

[85] S. Fourmaux, S. Payeur, S. Buffechoux, P. Lassonde, C. St-Pierre, F. Martin, J. C. Kieffer, "Pedestal cleaning for high laser pulse contrast ratio with a 100 TW class laser system," Opt. Express 19, 9, 8486 (2011).

[86] A. Renault, F. Augé-Rochereau, T. Planchon, P. D’Oliveira, T. Auguste, G. Chériaux, J.-P. Chambaret, "ASE contrast improvement with a non-linear filtering Sagnac interferometer," Opt. Commun. 248, 4-6, 535 (2005).

[87] R.W. Boyd, "Nonlinear Optics, ”p. 170, Academic, San Diego, Calif., (1992).

[88] A. Jullien, F. Auge-Rochereau, G. Cheriaux, J. P. Chambaret, P. d'Oliveira, T. Auguste, F. Falcoz, "High-efficiency, simple setup for pulse cleaning at the millijoule level by nonlinear induced birefringence," Opt. Lett. 29, 18, 2184 (2004).

[89] D. Homoelle, A.L. Gaeta, V. Yanovsky, G. Mourou, "Pulse contrast enhancement of high-energy pulses by use of a gas-filled hollow waveguide, ” Opt. Lett. 27, 18, 1646 (2002).

[90] M.P. Kalashnikov, E. Risse, H. Schonnagel, A. Husakou, J. Herrmann, W. Sandner, "Characterization of a nonlinear filter for the front-end of a high contrast double-CPA Ti:sapphire laser," Opt. Express 12, 21, 5088 (2004).

[91] N. G. Khodakovskiy, M. P. Kalashnikov, V. Pajer, A. Blumenstein, P. Simon, M. M. Toktamis, M. Lozano, B. Mercier, Z. Cheng, T. Nagy, "Generation of few-cycle laser pulses with high temporal contrast via nonlinear elliptical polarisation rotation in a hollow fibre compressor, " Laser Physics Letters, 16, 095001 (2019).

[92] N. Smijesh, X. Zhang, P. Fischer, A. A. Muschet, R. Salh, A. Tajalli, U. Morgner, L. Veisz, "Contrast improvement of sub-4 fs laser pulses using nonlinear elliptical polarization rotation," Opt. Lett. 44, 16, 4028 (2019).

[93] S. Szatmári, Z. Bakonyi, P. Simon, “Active spatial filtering of laser beams,” Opt. Commun. 134, 1-6, 199 (1997).

[94] A. Marcinkevičius, R. Tommasini, G. D. Tsakiris, K. J. Witte, E. Gaižauskas, U. Teubner, "Frequency doubling of multi-terawatt femtosecond pulses," Appl. Phys. B 79, 5, 547 (2004).

[95] D. Hillier, C. Danson, S. Duffield, D. Egan, S. Elsmere, M. Girling, E. Harvey, N. Hopps, M. Norman, S. Parker, P. Treadwell, D. Winter, T. Bett, "Ultrahigh contrast from a frequency-doubled chirped-pulse-amplification beamline,” Appl. Opt. 52, 18, 4258 (2013).

[96] C. Hooker, Y. Tang, O. Chekhlov, J. Collier, E. Divall, K. Ertel, S. Hawkes, B. Parry, P. P. Rajeev, "Improving coherent contrast of petawatt laser pulses," Opt. Express 19, 3, 2193 (2011).

[97] D. Kaganovich, J.R. Penano, M.H. Helle, D.F. Gordon, B. Hafizi, A. Ting, "Origin and control of the subpicosecond pedestal in femtosecond laser systems, " Opt. Lett. 38, 18, 3635 (2013).

[98] N. Minkovski, G.I. Petrov, S.M. Saltiel, O. Albert, J. Etchepare, "Nonlinear polarization rotation and orthogonal polarization generation experienced in a single-beam configuration," J. Opt. Soc. Am. B 21, 9, 1659 (2004).

[99] L. Canova, S. Kourtev, N. Minkovski, A. Jullien, R. Lopez-Martens, O. Albert, S.M. Saltiel, "Efficient generation of cross-polarized femtosecond pulses in cubic crystals with holographic cut orientation," Appl. Phys. Lett. 92, 231102 (2008). 
[100] V. Chvykov, P. Rousseau, S. Reed, G. Kalinchenko, V. Yanovsky, "Generation of $10^{\wedge} 11$ contrast 50 TW laser pulses, ” Opt. Lett. 31, 10, 1456 (2006).

[101] M.P. Kalashnikov, K. Osvay, G. Priebe, L. Ehrentraut, S. Steinke, W. Sandner, ”Temporal contrast of high intensity laser systems above $10^{\wedge} 11$ with double CPA technique," AIP Conf. Proc. 1462, 108 (2012).

[102] A. Ricci, A. Jullien, J-P. Rousseau, Y.Liu, A. Houard, P. Ramirez, D. Papadopoulos, A. Pellegrina, P. Georges, F. Duon, N. Forget, R. Lopez-Martens, ”Energy-scalable temporal cleaning device for femtosecond laser pulses based on cross-polarized wave generation, " Rev. Sci. Instrum. 84, 043106 (2013).

[103] J. Sung, H. W. Lee, J. Y. Yoo, J. W. Yoon, C. W. Lee, J. M. Yang, Y. J. Son, Y. H. Jang, S. K. Lee, C. H. Nam, "4.2 PW, 20 fs Ti:sapphire laser at 0.1 Hz, " Opt. Lett. 42, 11, 2058 (2017).

[104] P. Simon, H. Gerhardt, S. Szatmári, "'Intensity-dependent loss properties of window materials at 248 nm," Optics Lett. 14, 21, 1207 (1989).

[105] H. C. Kapteyn, A. Szoke, R. W. Falcone, M. M. Murnane, "Prepulse energy suppression for high-energy ultrashort pulses using self-induced plasma shuttering, " Opt.

Lett. 16, 7, 490 (1991).

[106] Ch. Ziener, P. S. Foster, E. J. Divall, C. J. Hooker, M. H. R. Hutchinson, A. J. Langley, D. Neely, "Specular reflectivity of plasma mirrors as a function of intensity, pulse duration, and angle of incidence," J. Appl. Phys. 93, 768 (2003).

[107] C. Rödel, M. Heyer, M. Behmke, M. Kübel, O. Jäckel, W. Ziegler, D. Ehrt, M.C. Kaluza, G.G. Paulus, "High repetition rate plasma mirror for temporal contrast enhancement of terawatt femtosecond laser pulses by three orders of magnitude, ” Appl Phys B 103, 295 (2011).

[108] A. Lévy, T. Ceccotti, P. D’Oliveira, F. Réau, M. Perdrix, F. Quéré, P. Monot, M. Bougeard, H. Lagadec, P. Martin, J.-P. Geindre, P. Audebert, "Double plasma mirror for ultrahigh temporal contrast ultraintense laser pulses, " Optics Lett. 32, 3, 310 (2007).

[109] G. Doumy, F. Quéré, O. Gobert, M. Perdrix, P. Martin, P. Audebert, J. C. Gauthier, J.-P. Geindre, T. Wittmann,"Complete characterization of a plasma mirror for the production of highcontrast ultraintense laser pulses," Phys. Rev. E 69, 026402 (2004).

[110] P. Martin, P. Monot, F. Doumy, S. Dobosz, M. Perdrix, F. Reau, P. D’Oliveira, F. Quere, P. Audebert, J.-P. Geindre, J.-P. Gauthier, T. Wittmann, "Utilization of a plasma mirror for the production of high-order harmonicsfrom a planar surface," Proc. SPIE 5482, 1, 55 (2004).

[111] T.Wittmann, J. P. Geindre, P. Audebert, R. S. Marjoribanks, J. P. Rousseau, F. Burgy, D. Douillet, T. Lefrou, K. Ta. Phuoc, J. P. Chambaret, "Towards ultrahigh-contrast ultraintense laser pulses - complete characterization of a double plasma-mirror pulse cleaner," Rev. Sci. Instrum. 77, 083109 (2006).

[112] C. Thaury, F. Quéré, J.-P. Geindre, A. Levy, T. Ceccotti, P. Monot, M. Bougeard, F. Réau, P. D'Oliveira, P. Audebert, R. Marjoribanks, Ph. Martin, "Plasma mirrors for ultrahigh-intensity optics, "Nat. Phys. 3, 427 (2007).

[113] G. Scott, V. Bagnoud, C. Brabetz, R. J. Clarke, J. S. Green, R. I. Heathcote, H. W. Powell, B. Zielbauer, T. D. Arber, P. McKenna, "Optimization of plasma mirror reflectivity and optical quality using double laser pulses," New Journal of Physics, 17, 033027 (2015).

[114] L. Obst, J. Metzkes-Ng, S. Bock, G. E. Cochran, T. E. Cowan, T. Oksenhendler, P. L. Poole, I. Prencipe, M. Rehwald, C. Rödel, "On-shot characterization of single plasma mirror temporal contrast improvement," Plasma Physics and Controlled Fusion, 60, 5 (2018).

[115] B. Gilicze, A. Barna, Z. Kovács, S. Szatmári, I. B. Földes, “Plasma mirrors for short pulse KrF lasers,” Rev. Sci. Instrum. 87, 8, 083101 (2016). 
[116] Barna Angéla, "Ultrarövid, ultraibolya lézerimpulzusok és magas harmonikusok diagnosztikája, ” PhD értekezés (2015)

[117] EB Treacy, "'Optical pulse compression with diffraction gratings, "' IEEE

J. Quantum Electron. QE-5, 454 (1969).

[118] B. Gilicze, R. Dajka, I. B. Földes, S. Szatmári, "Improvement of the temporal and spatial contrast of the nonlinear Fourier-filter, " Opt. Express 25, 17, 20791 (2017).

[119] J. W. Goodman, "Introduction to Fourier Optics, " Chap. 6. Roberts and Company (2005).

[120] B. Gilicze, Z. Homik, S. Szatmári, "High-contrast, high-brightness ultraviolet laser system," Opt. Express 27, 12, 17377 (2019).

[121] T. Nagy, Peter Simon, "Single-shot TG FROG for the characterization of ultrashort DUV pulses," Opt. Express 17, 10, 8144 (2009).

[122] P. Simon, T. Nagy, S. Szatmári, "Nonlinear spectral filtering of femtosecond pulses, " Opt. Comm. 145, 1-6, 155 (1998). 